\title{
CONSERVATION BIOGEOGRAPHY OF LOTIC FISHES IN THE MISSOURI AND COLORADO RIVER BASINS
}

\author{
A Dissertation \\ presented to \\ the Faculty of the Graduate School \\ at the University of Missouri-Columbia
}

In Partial Fulfillment

of the Requirements for the Degree

Doctor of Philosophy

by

LANDON L. PIERCE

Dr. Craig Paukert, Dissertation Supervisor

MAY 2019 
The undersigned, appointed by the dean of the Graduate School, have examined the dissertation entitled

CONSERVATION BIOGEOGRAPHY OF LOTIC FISHES IN THE MISSOURI AND COLORADO RIVER BASINS

presented by Landon Pierce, a candidate for the degree of doctor of philosophy, and hereby certify that, in their opinion, it is worthy of acceptance.

Dr. Craig P. Paukert

Dr. Michael A. Urban

Dr. Elisabeth B. Webb

Dr. Joanna B. Whittier 


\section{ACKNOWLEDGEMENTS}

I thank my family, especially Dad, Dennis, Lori, Duane, Lance, and Ashli for your support and motivation.

I thank Dr. Craig Paukert and Dr. Joanna Whittier for their guidance, friendship, and patience. I thank Dr. Elisabeth Webb, Dr. Michael Urban, and Dr. Dylan Kesler for their insight and guidance. I thank Dr. Mark Pegg and Dr. Brian Graeb for their guidance and inspiration.

I thank all of my great friends that have helped me through this extended, challenging journey: Sean Brozek, Caleb Penney, Codah Gatewood, Nate Elias, Brad Salber, Tyler Pool, David Weekley, Jordan Anderson, Tony Barada, Nate Gosch, Mike Greiner, Dan James, Mark Fincel, Casey and Kyle Heimerl, Will Schreck, Will French, Jake Davis, Jeff and Erin Fore, Emily Pherigo, Jason Harris, Andy Dinges, Nick Sievert, Leslie and Ryan Lueckenhoff, Jon and Hilary Spurgeon, Jake Faulkner, Jeremy Hammen, Dane Shuman, Kristen Grohs, William and Megan Ernst, Dylan and Marissa Turner, Mike and Mallory Smith, Jason Burt, and Rachal Brown.

Finally, I think all of the entities that contributed the data used in this study: Arizona Cooperative Fish and Wildlife Research Unit; Arizona Game and Fish Department; Arizona Natural Heritage Program; Arizona State University; Colorado Parks and Wildlife; Iowa Department of Natural Resources; Kansas Department of Wildlife, Parks and Tourism; Missouri Department of Conservation; Montana Fish, Wildlife and Parks; Missouri Resource Assessment Partnership (especially Michael Morey); University of New Mexico Museum of Southwestern Biology; Nebraska Game 
and Parks Commission; Nevada Department of Wildlife; New Mexico Environment Department; North Dakota Game and Fish; South Dakota Department of Game, Fish and Parks; San Juan River Basin Recovery Implementation Program; Upper Colorado Endangered Fish Recovery Program; U.S. Army Corps of Engineers; U.S. Environmental Protection Agency; U.S. Forest Service; U.S. Geological Survey; U.S. Fish and Wildlife Service; Utah Natural Heritage Program; and Wyoming Game and Fish Department. 


\section{TABLE OF CONTENTS}

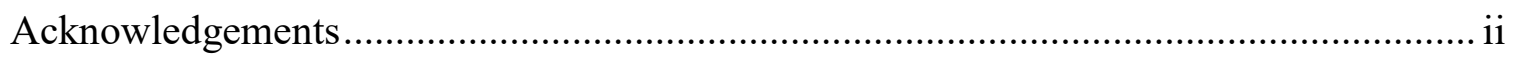

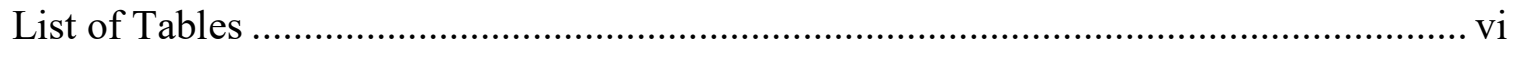

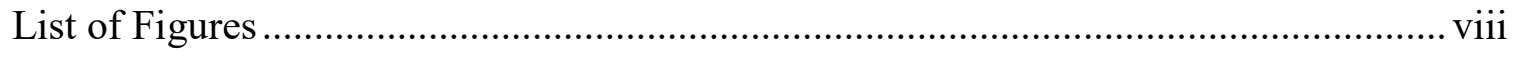

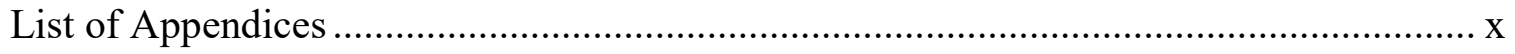

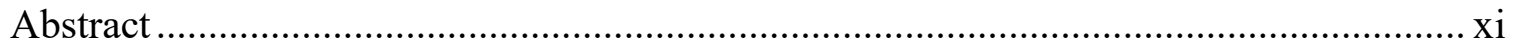

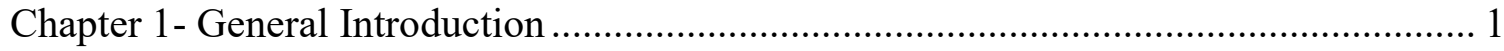

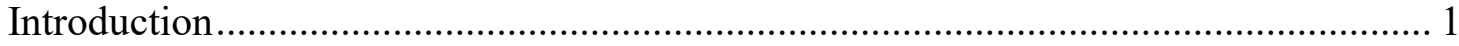

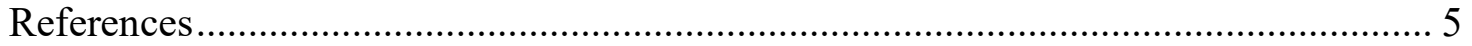

Chapter 2- Identifying Potentially Ecologically Important Tributaries of Large Rivers and Their Effects on Small-Bodied Fish Assemblage Structure ........................................ 11

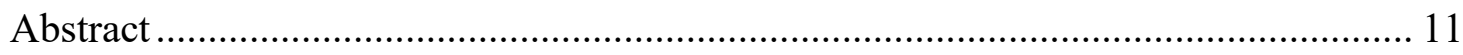

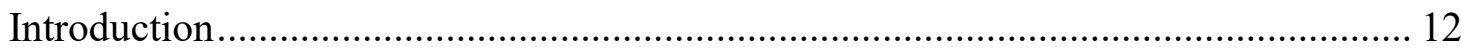

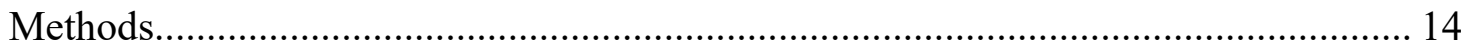

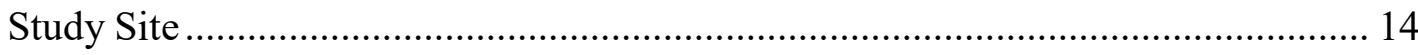

Identification of Potentially Ecologically Important Tributaries by Watershed

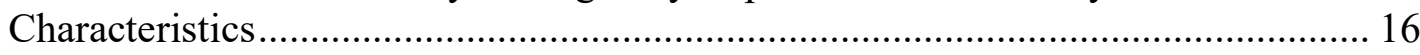

Effects of Potentially Ecologically Important Tributaries on Fish Assemblage

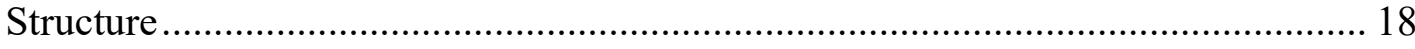

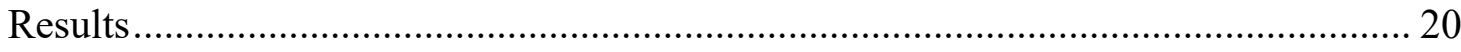

Identification of Potentially Ecologically Important Tributaries by Watershed

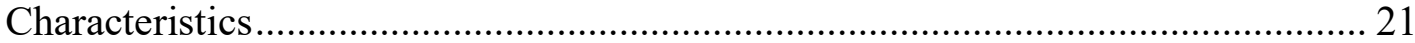

Effects of Potentially Ecologically Important Tributaries on Fish Assemblage

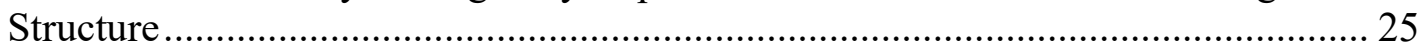

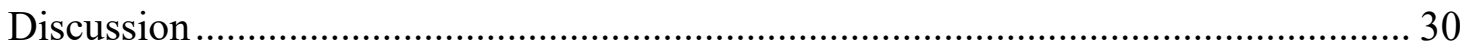

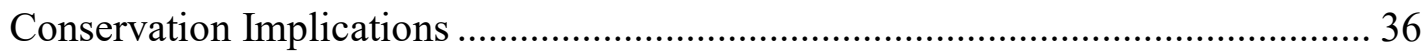

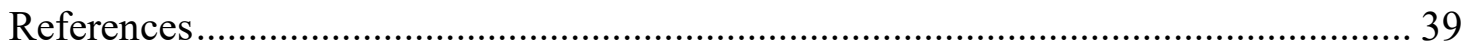

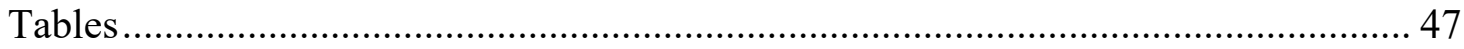

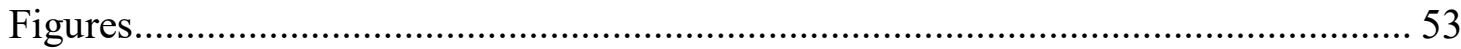

Chapter 3- Transferability of Species Distribution Models of Lotic Fishes Across River

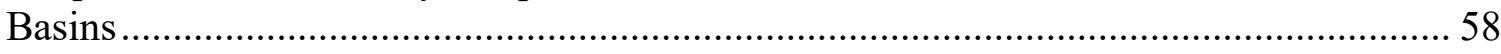

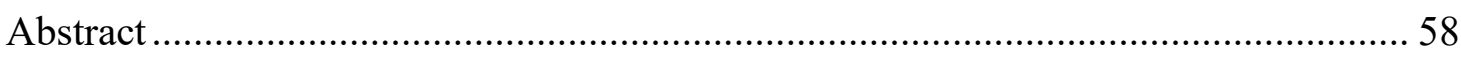

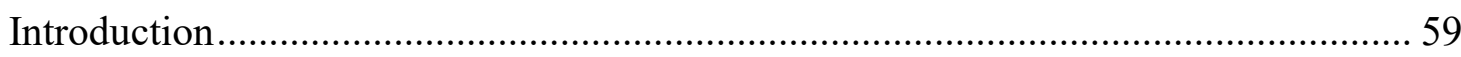

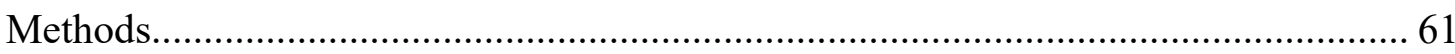




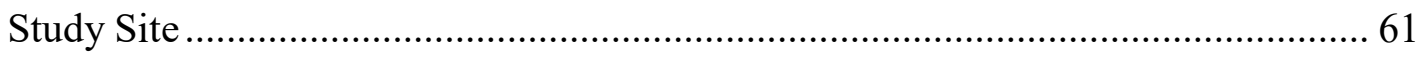

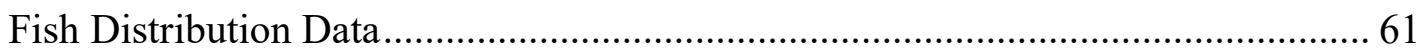

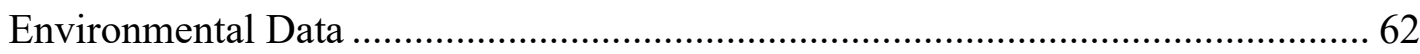

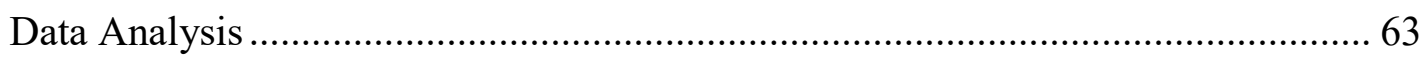

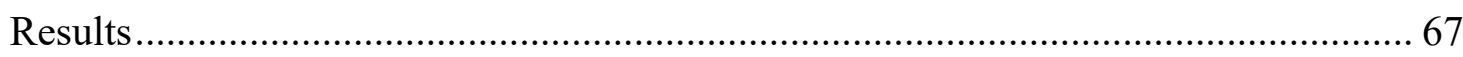

Transferability of Species Distribution Models Across Basins ................................... 67

Species Distribution Model Comparison Among Basins ............................................ 68

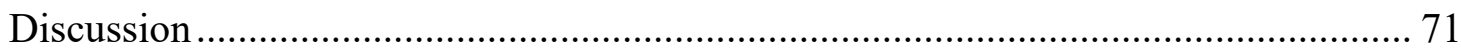

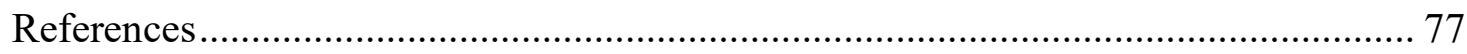

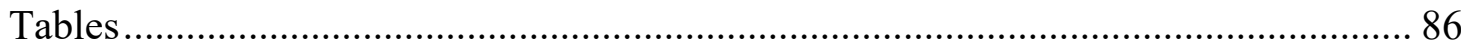

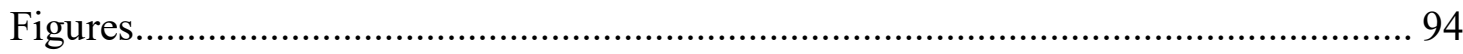

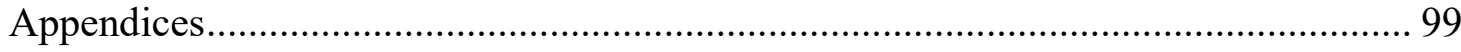

Chapter 4- Family-Level Evaluation of the Drivers of Non-Native Lotic Fish

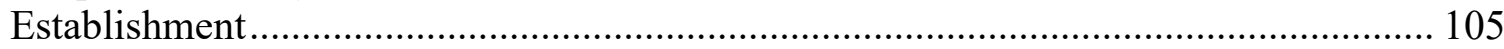

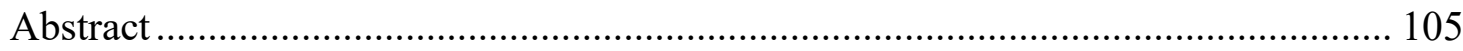

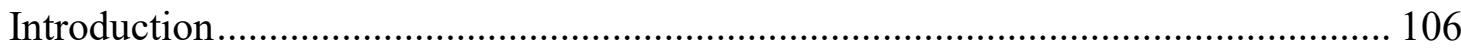

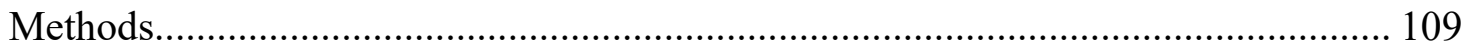

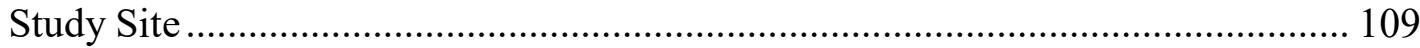

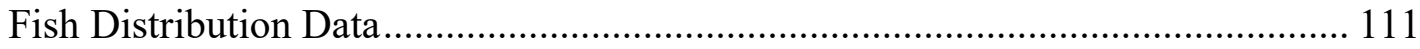

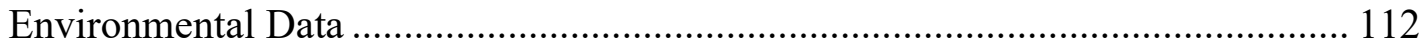

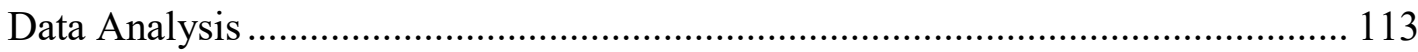

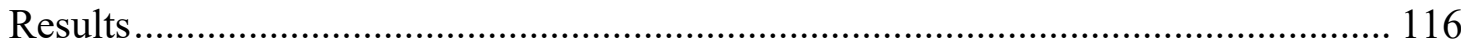

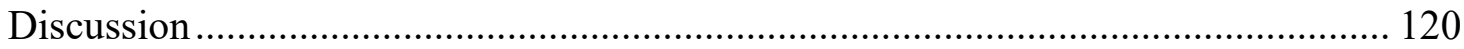

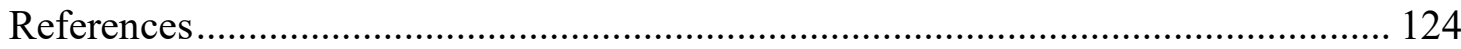

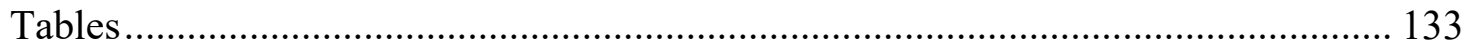

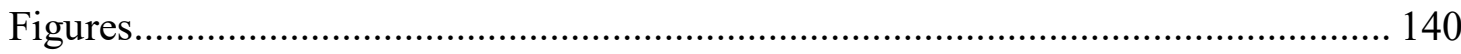

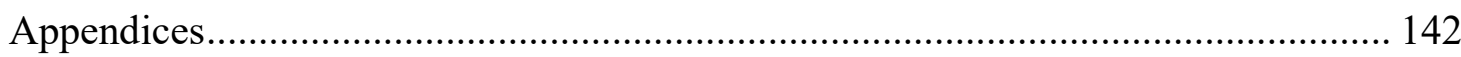

Chapter 5- Management Implications and Future Research........................................... 148

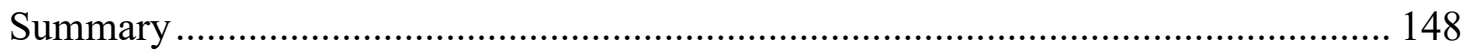

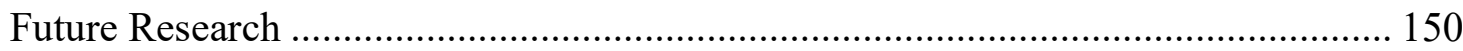

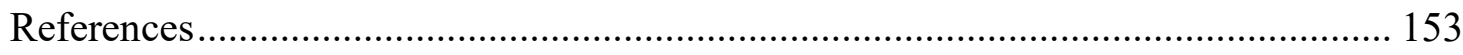

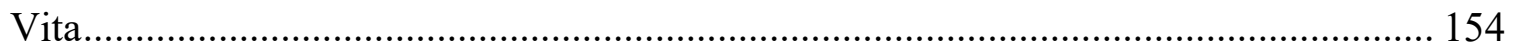




\section{LIST OF TABLES}

Table 2.1. Potentially ecologically important tributaries (PEIT) identified by watershed area, dam storage density, or non-carbonate surficial lithology for the Missouri, upper Colorado, Green, and San Juan Rivers. River km (Rkm) of confluences based on NHD stream network, and Colorado River values represent distance upstream of Glen Canyon Dam, AZ. Bold typeface indicates values of characteristics that resulted in PEIT. Watershed characteristic values presented for the mainstem upstream (US) and downstream (DS) of confluence, tributary (Trib), and tributary/upstream of the confluence (Trib:US).

Table 2.2. Percent of samples that each fish species occurred within 5 river km of potentially ecologically important tributary confluences in the Missouri (from 2005 to 2013), upper Colorado, Green, and San Juan Rivers (from 1990 to 2012). Bold typeface indicates species that occurred in $\geq 5 \%$ of samples and were used in discriminant analyses.

Table 3.1. Landscape-scale environmental variables used as predictor variables in multivariate adaptive regression spline species distribution models in the Missouri River (MRB) and Colorado River (CRB) basins. Variables without a code were excluded from models because they were highly correlated with other variables. 86

Table 3.2. Species characteristics, performance of multivariate adaptive regression spline species distribution models developed for the Missouri (MRB) and Colorado River (CRB) basins quantified as the area under the receiver-operating curve (AUC), model transferability from the MRB to the entire $\mathrm{CRB}(\mathrm{MRB} \rightarrow \mathrm{CRB})$ and ecological drainage units (EDU) that the species occurred $[\mathrm{MRB} \rightarrow \mathrm{CRB}(\mathrm{EDU})]$, and the difference in AUC between transferability $\mathrm{MRB} \rightarrow \mathrm{CRB}(\mathrm{EDU})$ and $\mathrm{MRB} \rightarrow \mathrm{CRB}[\Delta(\mathrm{EDU})] . \mathrm{I}=$ non-native; $\mathrm{N}=$ native for Nativity. G_NS= guarder, nest spawner; $\mathrm{NG}_{-} \mathrm{OS}=$ non-guarder, open substratum spawner, B_E $=$ external bearer, $\mathrm{NG}_{-} \mathrm{BH}=$ non-guarder, brood hider for Reproductive guild.

Table 3.3. Total number of species, number and percent of species whose multivariate adaptive regression spline species distribution models transferred from the Missouri River Basin to the Colorado River Basin, and average and standard deviation (SD) of area under the receiver-operating curve (AUC) values by species characteristic.

Table 3.4. Variable importance (delta deviance) of multivariate adaptive regression spline species distribution models (SDMs) developed in the Missouri (MRB) and Colorado (CRB) River basins by species and basin. Variable descriptions are available in Table 3.1 and species codes are in Table 3.2. Darker shading indicates higher values for each column. An asterisk (*) indicates species whose SDMs transferred from the CRB to MRB. Column headings MRB and CRB indicate the basin that SDMs were developed. 91

Table 4.1. Spearman rank correlation $\left(\mathrm{r}_{\mathrm{s}}\right)$ of landscape-level metrics of human activity for 1 st to 4 th order stream segments in the Missouri and Colorado River basins where fish were collected for this study. The top value represents $r_{s}$ and the bottom value represents 
the $\mathrm{p}$-value for each correlation. Values in bold indicate strong $\left(\mathrm{r}_{\mathrm{s}} \geq|0.6|\right)$ correlations. Prefixes "L_", "N_", and " $\mathrm{C}_{-}$" represent local catchment, network watershed, and cumulative spatial scales, respectively, of landscape-level environmental data.

Table 4.2. Logistic regression model results for Human Activity, Biotic Resistance, and Biotic Acceptance hypotheses predicting non-native Salmonidae presence in the Missouri and Colorado River basins. Interior Highlands was excluded from analysis by physiographic division due to low sample size. $\mathrm{k}=$ number of model parameters.

Table 4.3. Logistic regression model results for Human Activity, Biotic Resistance, and Biotic Acceptance hypotheses predicting non-native Cyprinidae presence in the Missouri and Colorado River basins. $\mathrm{k}=$ number of model parameters.

Table 4.4. Logistic regression model results for Human Activity, Biotic Resistance, and Biotic Acceptance hypotheses predicting non-native Catostomidae presence in the Missouri and Colorado River basins. Interior Highlands was excluded from analysis by physiographic division due to low sample size. $\mathrm{k}=$ number of model parameters. 


\section{LIST OF FIGURES}

Figure 2.1. Middle and lower Missouri River (right), and upper Colorado, Green, and San Juan Rivers (left) and subset of their tributaries. FRD=Fort Randall Dam, SD. GPD=Gavins Point Dam, NE-SD. FGD=Flaming Gorge Dam, UT. GCD=Glen Canyon Dam, AZ. Asterisks (*) indicate potentially ecologically important tributaries identified in this study, black dots $(\bullet)$ represent mainstem dams.

Figure 2.2. Longitudinal profile of watershed characteristics of the Missouri River downstream of Fort Randall Dam, SD (left) and the Colorado River from the Gunnison River to Glen Canyon Dam, AZ. Dotted lines indicate locations of potentially ecologically important tributaries. Dashed line represents location of Gavins Point Dam, NE-SD. Rkm=river kilometer. Letter designations ("A" - "E") represent cluster designations from $k$-means clustering analysis. Values of rkm based on NHD stream network.

Figure 2.3. Longitudinal profile of watershed characteristics of the Green River downstream of Flaming Gorge Dam, UT (left), and the San Juan River downstream of the Chaco River (right). Dotted lines indicate locations of potentially ecologically important tributaries. $\mathrm{Rkm}=$ river kilometer. Letter designations (" $\mathrm{A}$ " - "C") represent cluster designations from $k$-means clustering analysis. Values of rkm based on NHD stream network.

Figure 2.4. Discriminant analysis variable correlation scores for differentiating assemblages upstream (negative) and downstream (positive) of potentially ecologically important Missouri River tributaries: Niobrara (top), Platte (middle), and Osage Rivers (bottom).

Figure 2.5. Discriminant analysis variable correlation scores for differentiating assemblages upstream (negative) and downstream (positive) of potentially ecologically important tributaries of the Green (i.e., White River; top) and San Juan Rivers [i.e., Montezuma Creek (middle), and Chinle Creek (bottom)]

Figure 3.1. Number of multivariate adaptive regression spline species distribution models (SDMs) that a variable occurred (top) and mean importance (delta deviance) of variables that were included in SDMs (i.e., zeros excluded; bottom) for the Colorado (CRB) and Missouri (MRB) River basins. See Table 3.1 for variable descriptions. Line approximates $1: 1$.

Figure 3.2. Percent of variables from multivariate adaptive regression spline species distribution models (SDMs) developed from Colorado River basin (CRB) data that were in Missouri River basin (MRB) SDMs (i.e., variable overlap) and mean variable importance (delta deviance) of variables in CRB SDMs for variables that occurred in SDMs for both basins. Each point represents one species and is labeled by MRB SDM transferability: low $=\mathrm{AUC}<0.7$, high $=\mathrm{AUC} \geq 0.7$. 
Figure 3.3. Variable importance (delta deviance) of multivariate adaptive regression spline species distribution models (SDMs) developed for the Colorado (CRB) and Missouri (MRB) River basins for species whose SDMs transferred from the MRB to CRB......

Figure 3.4. Variable importance of multivariate adaptive regression spline species distribution models (SDMs) developed for the Colorado (CRB) and Missouri (MRB) River basins for species whose SDMs did not transfer from the MRB to CRB.

Figure 3.5. Predicted effect of mean annual air temperature on probability of occurrence for eight species whose most important variable in Colorado River (CRB) and Missouri River (MRB) basin multivariate adaptive regression spline species distribution models (SDMs) was mean annual temperature. Values represent the probability of occurrence at median value of all other environmental variables. Grey area represents temperatures available in $\mathrm{CRB}$ that are outside the temperature range available in the MRB. An asterisk (*) indicates species whose SDMs transferred from the MRB to the CRB....

Figure 4.1. Physiographic divisions (top; Fenneman and Johnson 1946) and biogeographical regions of the Missouri and Colorado River basins (MRB and CRB, respectively). Biogeographic regions were adapted from Cross et al. (1986) for the MRB and Minckley et al. (1986) for the CRB. 140

Figure 4.2. Predicted probability of non-native Salmonidae occurrence by physiographic division estimated from logistic regression at the global spatial extent (top), predicted probability of non-native Cyprinidae occurrence by native Cyprinidae occurrence in the Rocky Mountain System physiographic division (middle), and predicted probability of non-native Catostomidae occurrence as a function of native species richness in the Interior Plains physiographic division (bottom). 


\section{LIST OF APPENDICES}

Appendix 3.1. Mean variable importance of multivariate adaptive regression spline species distribution models (SDMs) developed in the Colorado (CRB) and Missouri (MRB) River basins by family and basin. Variable code descriptions are available in Table 3.1. Darker shading indicates higher values for each column. Column subheadings MRB and CRB indicate the basin that SDMs were developed.

Appendix 3.2. Mean variable importance of multivariate adaptive regression spline species distribution models (SDMs) developed in the Colorado (CRB) and Missouri (MRB) River basins by species nativity and basin. Variable code descriptions are available in Table 3.1. Darker shading indicates higher values for each column. Column subheadings MRB and CRB indicate the basin that SDMs were developed

Appendix 3.3. Mean variable importance of multivariate adaptive regression spline species distribution models (SDMs) developed in the Colorado (CRB) and Missouri (MRB) River basins by feeding guild and basin. Variable code descriptions are available in Table 3.1. Darker shading indicates higher values for each column. Column subheadings MRB and CRB indicate the basin that SDMs were developed

Appendix 3.4. Mean variable importance of multivariate adaptive regression spline species distribution models (SDMs) developed in the Colorado (CRB) and Missouri (MRB) River basins by substrate preference and basin. Variable code descriptions are available in Table 3.1. Darker shading indicates higher values for each column. Column subheadings MRB and CRB indicate the basin that SDMs were developed.

Appendix 3.5. Mean variable importance of multivariate adaptive regression spline species distribution models (SDMs) developed in the Colorado (CRB) and Missouri (MRB) River basins by temperature preference and basin. Variable code descriptions are available in Table 3.1. Darker shading indicates higher values for each column. Column subheadings MRB and CRB indicate the basin that SDMs were developed.

Appendix 3.6. Mean variable importance of multivariate adaptive regression spline species distribution models (SDMs) developed in the Colorado (CRB) and Missouri (MRB) River basins by reproductive guild and basin. Variable code descriptions are available in Table 3.1. Darker shading indicates higher values for each column. Column subheadings MRB and CRB indicate the basin that SDMs were developed 104

Appendix 4.1. Species occurrence (number of stream segments) and nativity by biogeographic region. An asterisk (*) indicates species that were considered non-native based on Minckley et al. (1986) for the Colorado River basin and Cross et al. (1986) for the Missouri River basin. Biogeographic region abbreviations represent CharitonNishnabotna (CN), Kansas (KS), Lower Missouri (LM), Platte-Niobrara (PN), SiouxJames (SJ), Upper Missouri (UM), White-Little Missouri (WL), Yellowstone (YS), Lower Colorado River Basin (LC), Middle Colorado River Basin (MC), and Upper Colorado River Basin (UC). 


\begin{abstract}
To improve our understanding of lotic fish ecology and improve conservation efforts, I 1) identified potentially ecologically important tributaries (PEITs) and evaluated their effects on fish assemble structure, 2) evaluated factors affecting spatial transferability of species distribution models (SDMs), and 3) evaluated the drivers of non-native fish establishment in the Missouri and Colorado River basins (MRB and CRB). The effects of PEIT likely vary among rivers as all Missouri River PEITs affected fish assemblage structure, but only half of upper Colorado River basin PEITs affected fish assemblage structure. Species distribution models transferred from the MRB to the CRB for 15 of 25 species, but transferability was not predictable based on species characteristics, re-enforcing the hypothesis that transferability is species- and contextspecific. Support for Human Activity, Biotic Resistance and Biotic Acceptance hypotheses as the drivers of non-native fish establishment varied by family, but these hypotheses rarely explained significant variability in the probability of non-native Salmonidae, Catostomidae, and Cyprinidae occurrence. These results may suggest that other factors (e.g., natural factors) drive non-native species distributions at the spatial (i.e., grain=stream segment; extents=physiographic divisions, and MRB and CRB combined) and taxonomic (i.e., family) scales considered in this study. This study aids conservations efforts by providing an efficient approach for identifying ecologically important tributaries and improving predictions of non-native species establishment.
\end{abstract}




\section{CHAPTER 1- GENERAL INTRODUCTION}

\section{Introduction}

Lotic ecosystems are in great need of conservation. Lotic ecosystems support high biodiversity of fish, invertebrates, plants, and algae, but also provide many human uses (e.g., food, navigation, power generation, drinking water, irrigation; Malmqvist and Rundle 2002). This human-dependency on lotic waters has resulted in lotic ecosystems becoming one of the most altered ecosystem classes in the world (Malmqvist and Rundle 2002) and freshwater species extinction rates similar to those of the most-impacted terrestrial ecosystem (i.e., tropical rainforest; Ricciardi and Rasmussen 1999). Approximately $39 \%$ of freshwater fish species in North America are imperiled; representing a 92\% increase since 1989 (Jelks et al. 2008). This trend will likely continue because the human population is predicted to increase from approximately 7.6 billion in 2017 to 11.2 billion in 2100 (UN 2017), and lotic fishes are expected to be impacted by future climate change (Abell 2002; Malmqvist and Rundle 2002).

Humans primarily affect lotic fishes through habitat alteration and species introductions (Malmqvist and Rundle 2002; Dudgeon et al. 2006). Habitat alteration was a causal factor in $73 \%$ of North American freshwater fish extinctions in the past century (Miller et al. 1989). Hydrological alteration (i.e., damming, channelization, and water removal) affects fish assemblages by inundating lotic habitats, modifying the timing and magnitude of stream flow, altering water temperatures, and increasing habitat fragmentation (Poff et al. 1997; Malmqvist and Rundle 2002; Roy et al. 2005). Meanwhile, land use changes affect water quality, substrate heterogeneity, water 
temperature, physical habitat, and allochthonous energy inputs (Malmqvist and Rundle 2002; Diana et al. 2006; Moerke and Lamberti 2006; Wehrly et al. 2006). Non-native species contributed to $68 \%$ of North American fish extinctions (Miller et al. 1989) and affect native fishes through predation (e.g., Shelton et al. 2015; Ballew et al. 2016; Ellender et al. 2018), competition (e.g., Love et al. 2018), hybridization (e.g., Muhlfeld et al. 2017), and disease transmission (Malmqvist and Rundle 2002; Gozlan et al. 2010; Cucherousset and Olden 2011). The effects of non-native species on native fishes likely increased recently because the number of non-native fish species in the USA was estimated to increase from 69 (in 1990) to 150 by 2025 (Malmqvist and Rundle 2002).

The ability to predict non-native fish establishment is critical to the conservation of native lotic fishes. Potential management approaches for non-native species include no action, preventing establishment to new areas (e.g., preventing introductions of new species or containment of established species), population control to reduce non-native species impacts, and eradication (Britton et al. 2011). Of these, preventative measures are often the most cost-effective options (Wittenberg and Cock 2001), but knowledge of the factors that affect non-native species establishment is needed to effectively prevent their spread (Blanchet et al. 2009).

The "Human Activity", "Biotic Acceptance", and "Biotic Resistance" hypotheses are often used to predict non-native species establishment (Olden et al. 2010). The Human Activity Hypothesis suggests that non-native species establishment is best predicted by human activities that increase propagule pressure (i.e., the number of species introductions or number of individuals introduced) or habitat alteration (Olden et al. 2010). The Biotic Acceptance Hypothesis predicts environmental conditions affect native 
and non-native species similarly, resulting in a positive relationship between native and non-native species richness (Fridley et al. 2007). Conversely, the Biotic Resistance Hypothesis predicts a negative relationship between native and non-native species richness because native species are expected to prevent non-native species establishment through competition and predation (Levine and D'Antonio 1999). Currently, the drivers of non-native species establishment in lotic ecosystems are uncertain, but resolving this information gap may help resource managers prevent future non-native species invasions.

An improved understanding of the ability of species distribution models (SDMs) to transfer between regions (i.e., spatial transferability) may also aid non-native species prevention efforts. Species distribution models predict areas where non-native species are likely to establish by applying a model developed in one area to an area of potential introduction (Olden and Jackson 2002; Peterson 2003), but accurate predictions rely on adequate transferability between regions (Randin et al. 2006; Wenger and Olden 2012; Huang and Frimpong 2016). Multiple biotic factors (e.g., ecological trait plasticity and species prevalence) were identified as potentially affecting SDM transferability (Elith and Leathwick 2009; Huang and Frimpong 2016), but it remains unclear if transferability of lotic fish SDMs is predictable based on species characteristics. The ability to predict if SDMs reliably transfer to new areas would allow resource managers to confidently implement non-native species prevention actions based on SDM predictions.

Although non-native species affect many lotic ecosystems, understanding the ability of tributaries to remediate the effects of hydrological alteration is especially important to the conservation of large river fishes. Many large rivers are impacted by impoundments (Hughes et al. 2005), but tributaries may reduce the effects of 
impoundment because they are sources of the abiotic factors affected by impoundment (e.g., sediment, turbidity, streamflow, and water temperature; Malmqvist and Rundle 2002; Rice et al. 2008). Currently, however, there is a lack of information on which tributaries are likely ecologically important to mainstem rivers and if tributary effects can be generalized across geographic regions (Rice et al. 2008). Therefore, developing an approach to identify tributaries that likely affect abiotic characteristics of large rivers may lead to improved management of large rivers by providing a means to target tributaries for research and conservation efforts.

I had a unique opportunity to evaluate how biotic and abiotic factors affect fish distributions and assemblage structure in the Colorado and Missouri River Basins to improve our understanding of the ecology of lotic fishes and inform conservation efforts. Specifically, my goals were to improve our ability to predict the establishment of nonnative species, and predict which tributaries are likely to be ecologically important and evaluate their effects on fish assemblage structure. To accomplish this goal, I conducted three independent studies:

Chapter 2- Identifying Potentially Ecologically Important Tributaries of Large Rivers and Their Effects on Small-Bodied Fish Assemblage Structure Chapter 3- Transferability of Species Distribution Models of Lotic Fishes Across River Basins

Chapter 4- Family-Level Evaluation of the Drivers of Non-Native Lotic Fish Establishment 
These studies were written as stand-alone manuscripts with co-authors for publication in peer-reviewed journals and, therefore, were written using the "we" pronoun and may contain redundant material.

\section{References}

Abell, R. 2002. Conservation biology for the biodiversity crisis: A freshwater follow-up. Conservation Biology 16:1435-1437.

Ballew, N. G., N. M. Bacheler, G. T. Kellison, and A. M. Schueller. 2016. Invasive lionfish reduce native fish abundance on a regional scale. Scientific Reports 6, 32169.

Blanchet, S., F. Leprieur, O. Beauchard, J. Staes, T. Oberdorff, and S. Brosse. 2009. Broad-scale determinants of non-native fish species richness are contextdependent. Proceedings of the Royal Society B 276:2385-2394.

Britton, J. R., R. E. Gozlan, and G. H. Copp. 2011. Managing non-native species. Fish and Fisheries 12:256-274.

Cucherousset, J., and J. D. Olden. 2011. Ecological impacts of non-native freshwater fishes. Fisheries 36:215-230.

Diana, M., J. D. Allan, and D. Infante. 2006. The influence of physical habitat and land use on stream fish assemblages in southeastern Michigan. Pages 359-374 in R. M. Hughes, L. Wang, and P. W. Seelbach, editors. Landscape influences on stream habitats and biological assemblages. American Fisheries Society, Symposium 48, Bethesda, MD. 
Dos Santos, D. A., D. J. Hoeinghaus, and L. C. Gomes. 2018. Spatial scales and the invasion paradox: A test using fish assemblages in a Neotropical floodplain. Hydrobiologia 817:121-131.

Dudgeon, D., A. H. Arthington, M. O. Gessner, Z. Kawabata, D. J. Knowler, C. Lévêque, R. J. Naiman, A. Prieur-Richard, D. Soto, M. L. J. Stiassny, and C. A. Sullivan. 2006. Freshwater biodiversity: Importance, threats, status and conservation challenges. Biological Reviews 81:163-182.

Elith, J., and J. R. Leathwick. 2009. Species distribution models: Ecological explanation and predictions across space and time. The Annual Review of Ecology, Evolution, and Systematics 40:677-697.

Ellender, B. R., O. L. Weyl, M. E. Alexander, A. M. Luger, L. A. Nagelkerke, L. A. and D. J. Woodford. 2018. Out of the pot and into the fire: Explaining the vulnerability of an endangered small headwater stream fish to black-bass Micropterus spp. invasion. Journal of Fish Biology 92:1035-1050.

Fridley, J. D., J. J. Stachowicz, S. Naeem, D. F. Sax, E. W. Seabloom, M. D. Smith, T. J. Stohlgren, D. Tilman, and B. Von Holle. 2007. The invasion paradox: Reconciling pattern and process in species invasions. Ecology 88:3-17.

Gozlan, R. E., J. R. Britton, I. Cowx, and G. H. Copp. 2010. Current knowledge on nonnative freshwater fish introductions. Journal of Fish Biology 76:751-786.

Huang, J., and E. A. Frimpong. 2016. Limited transferability of stream-fish distribution models among river catchments: Reasons and implications. Freshwater Biology 61:729-744. 
Hughes, R. M., J. N. Rinne, and B. Calamusso. 2005. Historical changes in large river fish assemblages in the Americas: A synthesis. Pages 603-612 in J. Rinne, R. M. Hughes, and B. Calamusso, editors. Historical changes in large river fish assemblages of the Americas. American Fisheries Society Symposium 45, Bethesda, MD.

Jelks, H. L., S. J. Walsh, N. M. Burkhead, S. Contreras-Balderas, E. Díaz-Pardo, D. A. Hendrickson, J. Lyons, N. E. Mandrak, F. McCormick, J. S. Nelson, S. P. Platania, B. A. Porter, C. B. Renaud, J. J. Schmitter-Soto, E. B. Taylor, and M. L. Warren Jr. 2008. Conservation status of imperiled North American freshwater and diadromous fishes. Fisheries 33:372-407.

Levine, J. M., and C. M. D'Antonio. 1999. Elton revisited: A review of evidence linking diversity and invasibility. Oikos 87:15-26.

Love, S. A., N. J. Lederman, R. L. Anderson, J. A. DeBoer, And A. F. Casper. 2018. Does aquatic invasive species removal benefit native fish? The response of gizzard shad (Dorosoma cepedianum) to commercial harvest of bighead carp (Hypophthalmichthys nobilis) and silver carp (H. molitrix). Hydrobiologia $817: 403-412$.

Malmqvist, B., and S. Rundle. 2002. Threats to running water ecosystems of the world. Environmental Conservation 29:134-153.

Miller, R. R., J. D., Williams, and J. E. Williams. 1989. Extinctions of North American fishes during the past century. Fisheries 14:22-38.

Moerke, A. H., and G. A. Lamberti. 2006. Relationships between land use and stream ecosystems: A multistream assessment in southwestern Michigan. Pages 323-338 
in R. M. Hughes, L. Wang, and P. W. Seelbach, editors. Landscape influences on stream habitats and biological assemblages. American Fisheries Society, Symposium 48, Bethesda, MD.

Muhlfeld C. C., R. P., R. Al-Chokhachy, S. J. Amish, J. L. Kershner, R. F. Leary, W. H. Lowe, G. Luikart, P. Matson, D. A. Schmetterling, B. B. Shepard, P. A. H. Wesley, D. Whited, A. Whiteley, and F. W. Allendorf. 2017. Legacy introductions and climatic variation explain spatiotemporal patterns of invasive hybridization in a native trout. Global Change Biology 23:4663-4674.

Olden, J. D., and D. A. Jackson. 2002. A comparison of statistical approaches for modelling fish species distributions. Freshwater Biology 47:1976-1955.

Olden, J. D., M. K. Kennard, F. Leprieur, P. A. Tedesco, K. O. Winemiller, and E. García-Berthou. 2010. Conservation biogeography of freshwater fishes: Past progress and future directions. Diversity and Distributions 16: 496-513.

Peterson, A. T. 2003. Predicting the geography of species invasions via ecological niche modeling. The Quarterly Review of Biology 78:419-433.

Poff, N. L., J. D. Allan, M. B. Bain, J. R. Karr, K. L. Prestegaard, B. D. Richter, R. E. Sparks, and J. C. Stromberg. 1997. The natural flow regime. BioScience 47:769784.

Randin, C. F., T. Dirnböck, S. Dullinger, N. E. Zimmerman, M. Zappa, and A. Guisan. 2006. Are niche-based distribution models transferable in space?. Journal of Biogeography 33:1689-1703.

Ricciardi, A., and J. B. Rasmussen. 1999. Extinction rates of North American freshwater fauna. Conservation Biology 13:1220-1222. 
Rice, S. P., P. Kiffney, C. Greene, and G. R. Pess. 2008. The ecological importance of tributaries and confluences. Pages 209-242 in S. P. Rice, A. G. Roy, and B. L. Rhoads, editors. River confluences and the fluvial network. John Wiley \& Sons, Ltd, Chichester, United Kingdom.

Roy, A. H., M. C. Freeman, B. J. Freeman, S. J. Wenger, W. E. Ensign, and J. L. Meyer. 2005. Investigating hydrologic alteration as a mechanism of fish assemblage shifts in urbanizing streams. Journal of the North American Benthological Society 24:656-678.

Shelton, J. M., M. J. Samways, and J. A. Day. 2015. Predatory impact of non-native rainbow trout on endemic fish populations in headwater streams in the Cape Floristic Region of South Africa. Biological Invasions 17:365-379.

UN (United Nations). 2017. World population prospects: The 2017 revision, key findings and advance tables. United Nations, New York. Available at https://population.un.org/wpp/Publications/. Accessed 1/16/2019.

Wehrly, K. E., M. J. Wiley, and P. W. Seelbach. 2006. The influence of landscape features on summer water temperatures in Lower Michigan streams. Pages 113127 in R. M. Hughes, L. Wang, and P. W. Seelbach, editors. Landscape influences on stream habitats and biological assemblages. American Fisheries Society, Symposium 48, Bethesda, MD.

Wenger, S. J., and J. D. Olden. 2012. Assessing transferability of ecological models: An underappreciated aspect of statistical validation. Methods in Ecology and Evolution 3:260-267. 
Wittenberg, R., and M. J. W. Cock, editors. 2001. Invasive alien species: A toolkit of best prevention and management practices. CAB International, Wallingford, Oxon, United Kingdom. 


\title{
CHAPTER 2- IDENTIFYING POTENTIALLY ECOLOGICALLY \\ IMPORTANT TRIBUTARIES OF LARGE RIVERS AND THEIR \\ EFFECTS ON SMALL-BODIED FISH ASSEMBLAGE STRUCTURE
}

\begin{abstract}
Many large river ecosystems are impacted by hydrological alterations, and tributaries have gained attention for their potential to remediate the impacts of these alterations. However, it is unclear which tributaries are most likely to affect large river ecosystems. We identified potentially ecologically important tributaries (PEIT) of the Missouri, San Juan, upper Colorado, and Green Rivers (USA) as those tributaries that created discontinuities in longitudinal trends in landscape-level environmental data of these rivers (i.e., watershed area, dam storage density, and predominant surficial lithology) using $k$-means cluster analysis. We then compared small-bodied fish assemblage structure upstream and downstream of a subset (i.e., those with sufficient fish sampling data) of PEIT with discriminant analysis to evaluate if these PEIT were associated with changes in fish assemblage structure. We identified one PEIT for the middle Missouri River, three for the San Juan River, and four each for the lower Missouri, upper Colorado, and lower Green Rivers. Half of PEIT were identified by dam storage density or surficial lithology but not watershed area, and only one PEIT was identified by watershed area without also being identified by dam storage density or surficial lithology. All Missouri River PEIT evaluated affected fish assemblage structure, whereas only a subset of PEIT of the Colorado, Green, and San Juan Rivers affected fish assemblage structure, potentially due to low species richness in these rivers relative to the
\end{abstract}


Missouri River. The importance of watershed characteristics for identifying PEIT and the effects of tributaries on fish assemblages likely vary among rivers. Our approach for identifying PEIT may be used to identify tributaries for conservation and restoration actions, delineate ecologically relevant sampling reaches, and identify tributaries that likely have distinct chemical signatures for microchemistry studies.

\section{Introduction}

An improved understanding of the effects of tributaries on mainstem rivers is critical to the conservation of large river ecosystems (Rice et al. 2008). Many large river ecosystems are impacted by hydrological alterations (e.g., channel morphology alteration, flow regulation, and flow diversion), but tributaries may remediate the effects of mainstem alteration because they reintroduce abiotic elements of rivers that were lost or altered (e.g., sediment, stream flow, and water temperature; Galat et al. 2001; Malmqvist and Rundle 2002; Rice et al. 2008) and serve as surrogate mainstem habitat (Brown and Coon 1994; Tyus and Saunders 2001; Pracheil et al. 2013). Furthermore, tributary confluences are considered biodiversity hotspots due to increased habitat and biological diversity (Benda et al. 2004b; Fernandes et al. 2004; Kiffney et al. 2006; Rice et al. 2006; Rice et al. 2008).

The ecological effects of tributaries on mainstem rivers may depend on tributary watershed characteristics, but research is needed to identify which tributaries are likely ecologically important and improve our understanding of their effects on large river ecosystems. The Link Discontinuity Concept indicates that, at intermediate spatial scales (i.e., 1-100 km), a small number of tributaries provide sufficient streamflow and sediment to create discontinuities in the longitudinal pattern of hydrological and geomorphological 
conditions of rivers and, ultimately, affect ecosystem structure or processes (Rice et al. 2001). These tributary inputs (i.e., streamflow and sediment) are ultimately driven by watershed characteristics (e.g., size, geology, soil characteristics, land use, hydroclimate, geomorphology, and vegetation; Hynes 1975; Rice et al. 2001; Sable and Wohl 2006; Charlton 2008), so understanding tributary effects on mainstem watershed characteristics may provide insight on the ecological effects of tributaries on large river ecosystems. The ecological effects of tributaries are also dependent on the degree of tributary impoundment because unimpounded tributaries likely provide more natural sediment, temperature, and flow regimes than impounded tributaries (Rice et al. 2008). Finally, the effects of tributaries on mainstem rivers may vary between different climatic regions, as Benda et al. (2004a) found that fewer tributaries in arid environments were geomorphically significant than tributaries in humid environments, potentially due to differences in disturbance regimes. Currently, however, our knowledge of the mechanisms responsible for tributary effects, the generality of tributary effects across rivers and regions, and our ability to predict which tributaries are most likely ecologically important within a river network is lacking (Rice et al. 2008). Addressing these information gaps would improve large river conservation efforts by allowing ecologically important tributaries to be efficiently identified and targeted for management actions.

To improve large river conservation efforts, the objectives of this study were to develop an approach for identifying potentially ecologically important tributaries (PEIT) based on watershed characteristics, evaluate the effects of these tributaries on smallbodied fish assemblage structure, and compare characteristics of PEIT and their effects on fish assemblage structure among diverse river basins. We used the Missouri, 
Colorado, Green and San Juan Rivers to illustrate our approach across a range of river sizes, climate, and hydrological alteration.

\section{Methods}

\section{$\underline{\text { Study Site }}$}

We focused on two reaches of the Missouri River: 1) the middle Missouri River from Fort Randall Dam, South Dakota [river km (rkm) 1,416] to Gavins Point Dam, Nebraska-South Dakota (rkm 1,305), and 2) the lower Missouri River (i.e., Gavins Point Dam to the confluence of the Mississippi River; Figure 2.1). The Missouri River basin is primarily ( $70 \%$ of basin area) composed of the semi-arid ( $32 \mathrm{~cm}$ mean annual precipitation), highly erodible Great Plains, but the lower Missouri River basin is composed of the more humid Central Lowlands (40-102 cm mean annual precipitation) and Ozark Plateau physiographic provinces (> $100 \mathrm{~cm}$ mean annual precipitation; Galat et al. 2005b). The Missouri River was historically a turbid, warmwater river characterized by a braided channel with numerous islands and sandbars, but impoundments and channelization have substantially altered habitat, sediment load, water temperature, flow regimes, and subsequently, fish populations (Galat et al. 2005a, 2005b). We delineated the Missouri River into two reaches to prevent mainstem impoundment (i.e., Gavins Point Dam) from confounding our results. The middle Missouri River has altered temperature, flow, and sediment regimes due to impoundment, and is composed of approximately $71 \mathrm{rkm}$ of unchannelized river from Fort Randall Dam to the headwaters of Lewis and Clark Lake, Nebraska-South Dakota, and 40 rkm of reservoir (Galat et al. 2005b). The lower Missouri River has an altered flow regime due to upstream reservoirs and is unchannelized from Gavins Point Dam to Sioux City, Iowa (rkm 1,178), but is 
channelized and leveed from Sioux City to the confluence with the Mississippi River (Galat et al. 2005a, 2005b). The Missouri River supports 136 fish species (106 native species), and species richness increases from the upper Missouri River (64 species) to the lower Missouri River (110 species; Galat et al. 2005a).

We also examined three river reaches in the upper Colorado River basin: 1) the Green River downstream of Flaming Gorge Dam, Wyoming (rkm 661) to its confluence with the Colorado River, 2) $\geq 7^{\text {th }}$ order (based on NHDPlus Version 1; USEPA 2005) reaches of the upper Colorado River (i.e., confluence of the Gunnison River to Glen Canyon Dam, Arizona), and 3) $\geq 7^{\text {th }}$ order reaches of the San Juan River (i.e., downstream of the Chaco River; rkm 357) located in Utah, New Mexico, Colorado, and Wyoming (Figure 2.1). The Colorado River basin is primarily semi-arid shrub lands and desert shrubs, and the large rivers of the basin flow primarily through highly erodible, sedimentary deposits (Blinn and Poff 2005). Mean annual precipitation in the upper Colorado River basin is $22 \mathrm{~cm} / \mathrm{yr}$, and most of the streamflow of the Green, upper Colorado, and San Juan Rivers originates as mountain snowmelt (Blinn and Poff 2005). These rivers were historically turbid, warmwater rivers, but, like the Missouri River, sediment, temperature, and flow regimes of the Green River are substantially influenced by a mainstem dam (i.e., Flaming Gorge Dam; Blinn and Poff 2005). Although the upper Colorado and San Juan Rivers are impounded, these dams impound smaller portions of the watershed (i.e., $\leq 8,400 \mathrm{~km}^{2}$ ). In addition to habitat fragmentation and alteration caused by dams, these rivers have lost habitat diversity due to local channelization efforts associated with human development (Valdez and Muth 2005). Fish species richness is lower in the upper Colorado River basin than in the Missouri River basin; there are 
approximately 65 species (14 native) in the entire upper Colorado River basin, with 37 species (12 native) in the Green River, and 26 species (7 native) in the San Juan River (Blinn and Poff 2005; Valdez and Muth 2005).

Identification of Potentially Ecologically Important Tributaries by Watershed Characteristics

Consistent with the Link Discontinuity Concept (Rice et al. 2001), we identified potentially ecologically important tributaries (PEIT) as those tributaries that created discontinuities in the longitudinal profile of watershed characteristics of mainstem rivers. We evaluated longitudinal trends of watershed area, non-carbonate residual material surficial lithology (percent of watershed), and dam storage density (i.e., volume of water stored in reservoirs/watershed area) to represent tributary size, potential sediment inputs, and hydrological alteration, respectively. For each mainstem river, we quantified upstream watershed characteristics (dam storage density and surficial lithology) for each stream segment (NHDPlus Version 1; USEPA and USGS 2005) using the Catchment Attribute Allocation and Accumulation Tool (http://www. horizon-systems.

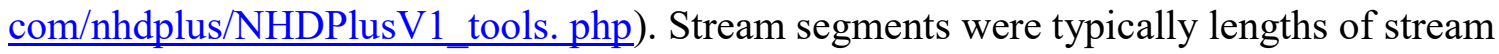
extending between two confluences, but were shorter if side channels, divergences, or other features occurred (McKay et al. 2012). We acquired surficial lithology data from Cress et al. (2010) to represent surficial and bedrock geology characteristics that may affect sediment dynamics. We evaluated trends in non-carbonate residual material because it was the predominant surficial lithology class (i.e., greater percent of watershed than any other lithology class) for the middle and lower Missouri River, upper Colorado River, lower Green River, and the San Juan River. Non-carbonate residual material is 
formed by the chemical and physical breakdown of non-carbonate (i.e., non-limestone or other carbonate rocks) bedrock such as sedimentary rock (Soller and Reheis 2004). Other common (> 5\% watershed area) lithology types in the Missouri River basin included loamy glacial till, fine- and coarse-textured eolian sediment, and alluvium and finetextured coastal zone sediment. Coarse-textured eolian sediment, silicic residual material, and alluvium and fine-textured coastal zone sediment were common lithology types in the upper Colorado River basin. We acquired dam storage data from the 2010 National Inventory of Dams database (USACE 2010) and remediated obvious errors in the dataset (e.g., duplicate records) prior to quantifying dam storage density. We acquired watershed area $\left(\mathrm{km}^{2}\right)$ values from the NHDPlus database (USEPA and USGS 2005).

We used $k$-means cluster analysis to group stream segments of each river that had similar values separately for each watershed characteristic. Next, we arranged segments longitudinally from upstream to downstream and identified the tributaries that caused changes in group membership as PEIT. $K$-means cluster analysis groups samples into a pre-determined number of clusters (i.e., $k$ ) based on their Euclidian distances (i.e., straight-line distance; Kwak and Peterson 2007) using a variance-minimizing algorithm to minimize the distance within groups. To provide an unbiased means of determining the appropriate number of groups, we determined the optimal number of clusters by evaluating the relationship between model fit (i.e., $R^{2}$ ) and $k$ (Kwak and Peterson 2007) and selected the value of $k$ such that subsequent clusters did not improve $R^{2}$ by $\geq 0.05$. We fixed the random number seed to ensure replicability of our analyses and used the "nstart" option (nstart=25) in R software (R Core Team 2015) to find the optimum initial centroids because the $k$-means clustering procedure depends on initial centroid location 
for each cluster (Tan et al. 2005). We calculated the ratio of tributary watershed characteristic to mainstem watershed characteristic immediately upstream of the confluence (i.e., "trib:US") to illustrate how watershed characteristics of PEIT compared to the mainstem. A trib:US value near one indicated that the tributary and mainstem had similar values of the watershed characteristic, a value $>1$ indicated that the tributary had a higher value of a watershed characteristic than the mainstem, and a value $<1$ indicated that the tributary had a lower value of a watershed characteristic than the mainstem. Effects of Potentially Ecologically Important Tributaries on Fish Assemblage Structure

We acquired small-bodied fish sampling data from the Upper Colorado River Endangered Fish Recovery Program (1990-2012) for the Colorado, Green, and San Juan Rivers, and the Pallid Sturgeon Population Assessment and Associated Fish Community Monitoring Program (2005-2013) for the Missouri River. These programs conduct standardized sampling during the summer and fall to collect age- 0 and small-bodied fishes. The Upper Colorado River Endangered Fish Recovery Program sampled with seines (0.32 mm mesh, $4.6 \mathrm{~m}$ long, $1.2 \mathrm{~m}$ deep; USFWS 1987) in backwater areas, and the Pallid Sturgeon Population Assessment and Associated Fish Community Monitoring Program sampled shallow water $(\leq 1.2 \mathrm{~m})$ habitats with mini-fyke nets (3-mm ace mesh; Welker and Drobish 2016, Welker et al. 2016). We chose to evaluate the effects of tributaries on small-bodied and age- 0 fishes to reduce the potential effects of migratory behavior (common to adult, large-bodied riverine species) on our analyses.

For each PEIT, we evaluated differences between the fish assemblage upstream of the confluence and the fish assemblage downstream of the confluence with discriminant analysis. Discriminant analysis identifies linear combinations of species-specific relative 
abundance data that best discriminate between assemblages (i.e., discriminant functions) and provides discriminant function-variable (i.e., species) correlation scores that describe each species' influence in discriminating between assemblages (Kwak and Peterson 2007). We limited our analyses to fish samples that occurred within $5 \mathrm{rkm}$ of PEIT confluences to reduce the potential of large-scale longitudinal changes in fish assemblage structure (Vannote et al. 1980; Galat et al. 2005a; Pegg and Pierce 2002b) obscuring the effects of tributaries that may occur if larger reaches were examined, while also being consistent with the scale of geomorphic effects of tributaries (Benda et al. 2004b). When multiple PEIT occurred within 5 rkm of each other (i.e., Sagers Wash and Dolores River in the upper Colorado River), sample reaches were delineated by the location of the adjacent PEIT to reduce confounding effects of multiple PEIT. Samples that occurred in mainstem river side channels near confluences (e.g., Niobrara River confluence) were excluded from the analysis if we were unable to determine based on aerial imagery and sampling location if they were upstream or downstream of the confluence. We limited our analysis to common species (i.e., present in $\geq 5 \%$ of samples per confluence) because rare species are unlikely to affect fish community dynamics, but may obscure meaningful trends if included in analyses (Kwak and Peterson 2007). Fish data was summarized to catch per unit effort (CPUE) as fish per net (seine) or fish per net-night (mini-fyke net) and $\log$ transformed [i.e., $\left.\log _{10}(\mathrm{CPUE}+1)\right]$ prior to analysis to improve normality. We used leave-one out cross validation to assess the accuracy of assemblage predictions (i.e., upstream or downstream of PEIT) from the discriminant analysis. We limited our evaluation of the effects of PEITs on fish assemblage structure to PEIT with at least 20 samples per assemblage (i.e., $\geq 20$ samples from the upstream assemblage and $\geq 20$ 
samples from the downstream assemblage; Kwak and Peterson 2007). Sample size requirements necessitated pooling samples across years, but $40-82 \%$ of samples were paired (upstream and downstream) within years for each confluence. For example, if 10 samples occurred upstream of the confluence and 5 samples occurred downstream of the confluence in a year, then $67 \%(\mathrm{n}=10 / 15)$ of samples were paired within that year [i.e., $(5$ upstream samples +5 downstream samples)/ 15 total samples].

\section{Results}

The middle Missouri River contained 75 stream segments, and the lower Missouri River contained 606 streams segments. Watershed area increased from $649.810^{3} \mathrm{~km}^{2}$ at Fort Randall Dam to $686.410^{3} \mathrm{~km}^{2}$ at Gavins Point Dam, and to $1,231.810^{3} \mathrm{~km}^{2}$ at the confluence of the Mississippi River (Figure 2.2). Dam storage density decreased from $121.710^{3} \mathrm{~m}^{3} / \mathrm{km}^{2}$ at Fort Randall Dam to $115.710^{3} \mathrm{~m}^{3} / \mathrm{km}^{2}$ immediately upstream of Gavins Point Dam. Dam storage density decreased from $116.710^{3} \mathrm{~m}^{3} / \mathrm{km}^{2}$ at Gavins Point Dam to $104.910^{3} \mathrm{~m}^{3} / \mathrm{km}^{2}$ at the confluence of the Mississippi River, with a minimum of $95.410^{3} \mathrm{~m}^{3} / \mathrm{km}^{2}$ immediately upstream of the Osage River (Figure 2.2). Percent watershed non-carbonate surficial lithology decreased from 59.4 at Fort Randall Dam to 40.7 at the Mississippi River confluence, with a minimum of 40.3 immediately upstream of the Osage River (Figure 2.2).

The upper Colorado River had 352 stream segments. Watershed area increased from $43.410^{3} \mathrm{~km}^{2}$ at the confluence of the Gunnison River to $275.710^{3} \mathrm{~km}^{2}$ at Glen Canyon Dam (Figure 2.2). Dam storage density decreased from $105.010^{3} \mathrm{~m}^{3} / \mathrm{km}^{2}$ at the confluence of the Gunnison River to $55.110^{3} \mathrm{~m}^{3} / \mathrm{km}^{2}$ at Glen Canyon Dam. Percent non- 
carbonate surficial lithology increased from 52.4 at the confluence of the Gunnison River to 73.4 at Glen Canyon Dam.

The lower Green River reach was composed of 472 stream segments. Watershed area increased from $38.410^{3} \mathrm{~km}^{2}$ at Flaming Gorge Dam to $114.410^{3} \mathrm{~km}^{2}$ at the confluence of the Colorado River (Figure 2.3). Dam storage density decreased from $137.410^{3} \mathrm{~m}^{3} / \mathrm{km}^{2}$ at Flaming Gorge Dam to $70.010^{3} \mathrm{~m}^{3} / \mathrm{km}^{2}$ at the confluence of the Colorado River. Percent watershed non-carbonate surficial lithology increased from 72.5 at Flaming Gorge Dam to 78.6 at the confluence of the Colorado River.

The San Juan River had 236 stream segments. Watershed area increased from $38.810^{3} \mathrm{~km}^{2}$ at the confluence of the Chaco River to $62.910^{3} \mathrm{~km}^{2}$ at the confluence of the Colorado River (Figure 2.3). Dam storage density decreased from $48.010^{3} \mathrm{~m}^{3} / \mathrm{km}^{2}$ at the confluence of the Chaco River to $26.410^{3} \mathrm{~m}^{3} / \mathrm{km}^{2}$ at the confluence of the Colorado River. Percent watershed non-carbonate surficial lithology decreased from 76.2 at the confluence of the Chaco River to 73.6 at the confluence of the Colorado River. Identification of Potentially Ecologically Important Tributaries by Watershed $\underline{\text { Characteristics }}$

In the middle Missouri River, two clusters were identified for watershed area $\left(R^{2}=0.99\right)$, surficial lithology $\left(R^{2}=0.99\right)$, and dam storage density $\left(R^{2}=0.99\right.$; Table 2.1 ; Figure 2.2). The Niobrara River was the only PEIT identified and created discontinuities in all three watershed characteristics. The Niobrara River increased watershed area from 645.3 to $683.910^{3} \mathrm{~km}^{2}$, but decreased dam storage density from 120.9 to $116.110^{3} \mathrm{~m}^{3} /$ $\mathrm{km}^{2}$ and non-carbonate surficial lithology from 59.0 to $57.5 \%$. 
Four PEIT were identified in the lower Missouri River. Two PEIT created discontinuities in watershed area $\left(k=3 ; R^{2}=0.97\right)$, two created discontinuities in surficial lithology $\left(k=3 ; R^{2}=0.95\right)$, and three created discontinuities in dam storage density $(k=3$; $R^{2}=0.90$; Table 2.1; Figure 2.2). The Big Sioux River was identified as a PEIT by dam storage density and decreased dam storage density from 108.6 to $106.010^{3} \mathrm{~m}^{3} / \mathrm{km}^{2}$ (Table 2.1). The Platte River was identified as a PEIT based on watershed area, dam storage density, and surficial lithology. The Platte River increased watershed area from 785.7 to $945.510^{3} \mathrm{~km}^{2}$, and decreased dam storage density from 103.3 to $100.210^{3} \mathrm{~m}^{3}$ / $\mathrm{km}^{2}$ and watershed non-carbonate surficial lithology from 50.0 to $46.5 \%$. The Kansas River, identified by watershed area and surficial lithology, increased watershed area from 980.7 to $1,128.910^{3} \mathrm{~km}^{2}$ and decreased watershed non-carbonate surficial lithology from 45.1 to $41.2 \%$. The Osage River was identified by dam storage density, and increased dam storage density from 95.4 to $106.110^{3} \mathrm{~m}^{3} / \mathrm{km}^{2}$.

Four PEIT were identified for the upper Colorado River: Sagers Wash, Dolores River, Green River, and San Juan River (Table 2.1; Figure 2.2). Two PEIT were identified by watershed area $\left(k=3 ; R^{2}=0.99\right)$, two were identified by surficial lithology $\left(k=3 ; R^{2}=0.99\right)$, and three were identified by dam storage density $\left(k=4 ; R^{2}=0.97\right)$. Sagers Wash, identified by dam storage density, decreased dam storage density from 93.0 to $91.810^{3} \mathrm{~m}^{3} / \mathrm{km}^{2}$ (Table 2.1). The Dolores River was identified by surficial lithology, and increased watershed non-carbonate surficial lithology from 57.3 to $63.6 \%$. The Green River was identified as a PEIT by watershed area, surficial lithology, and dam storage density. The Green River increased watershed area from 67.7 to $182.110^{3} \mathrm{~km}^{2}$, increased non-carbonate surficial lithology from 63.9 to $73.2 \%$, and decreased dam storage density 
from 80.7 to $74.010^{3} \mathrm{~m}^{3} / \mathrm{km}^{2}$. The San Juan River, identified by watershed area and dam storage density, increased watershed area from 205.9 to $268.810^{3} \mathrm{~km}^{2}$ and decreased dam storage density from 65.7 to $56.510^{3} \mathrm{~m}^{3} / \mathrm{km}^{2}$.

We identified four PEIT for the Green River: Vermillion Creek, Yampa River, White River, and Willow Creek (Table 2.1; Figure 2.3). Two PEIT were identified by watershed area $\left(k=3 ; R^{2}=0.95\right)$, one was identified by dam storage density $\left(k=2 ; R^{2}=0.93\right)$, and two were identified by non-carbonate surficial lithology $\left(k=3 ; R^{2}=0.92\right)$. Vermillion Creek and Willow Creek were identified as PEIT by surficial lithology. Vermillion Creek increased watershed non-carbonate surficial lithology from 73.3 to $74.5 \%$, and Willow Creek increased watershed non-carbonate surficial lithology from 77.0 to $77.5 \%$ (Table 2.1). The Yampa River was identified as a PEIT by watershed area and dam storage density. The Yampa River increased watershed area from 43.1 to $64.310^{3} \mathrm{~km}^{2}$, and decreased dam storage density from 122.9 to $86.510^{3} \mathrm{~m}^{3} / \mathrm{km}^{2}$. The White River was identified by watershed area and increased watershed area from 78.3 to $91.110^{3} \mathrm{~km}^{2}$.

We identified three PEIT for the San Juan River: Mancos River, Montezuma Creek, and Chinle Creek (Table 2.1; Figure 2.3). One PEIT was identified by watershed area $\left(k=2 ; R^{2}=0.93\right)$, two PEIT were identified by dam storage density $\left(k=3 ; R^{2}=0.97\right)$, and three PEIT were identified by non-carbonate surficial lithology $\left(k=3 ; R^{2}=0.98\right)$. The Mancos River was identified as a PEIT by dam storage density and non-carbonate surficial lithology. The Mancos River increased non-carbonate surficial lithology from 76.9 to $78.0 \%$ and decreased dam storage density from 44.8 to $42.710^{3} \mathrm{~m}^{3} / \mathrm{km}^{2}$. Montezuma Creek, identified by surficial lithology, decreased non-carbonate surficial lithology from 77.8 to $76.5 \%$. Chinle Creek was identified as a PEIT by watershed area, 
surficial lithology, and dam storage density. Chinle Creek increased watershed area from 47.0 to $57.010^{3} \mathrm{~km}^{2}$, decreased non-carbonate surficial lithology from 75.8 to $73.8 \%$, and decreased dam storage density from 35.3 to $29.110^{3} \mathrm{~m}^{3} / \mathrm{km}^{2}$.

Across mainstem rivers, eight (50\%) tributaries were identified as PEIT based on watershed area. Seven of these tributaries were also identified by surficial lithology or dam storage density. Most PEIT identified by watershed area were $\geq 15 \%$ the size of the mainstem (i.e., trib:US $\geq 0.15$; Table 2.1). However, the Niobrara River was identified by watershed area with a tributary: mainstem size ratio of 0.05 for the relatively short middle Missouri River. Tributaries identified as PEIT by surficial lithology or dam storage density but not watershed area typically had watershed area $\leq 7 \%$ of the mainstem (i.e., trib:US $\leq$ 0.07; Table 2.1). The Dolores River (Colorado River PEIT) was not identified by watershed area despite having greater relative watershed area (trib:US $=0.24$ ) than two PEIT identified by watershed area in the upper Colorado River basin [i.e., White River (Green River PEIT) trib:US=0.16; Chinle Creek (San Juan River PEIT) trib:US=0.21; Table 2.1].

Eight PEIT were identified by surficial lithology or dam storage density but not by watershed area. These PEIT had surficial lithology or dam storage densities that differed considerably from the mainstem river. The five PEIT (all upper Colorado River basin) identified by lithology but not watershed area had watersheds $3-24 \%$ the size of the mainstem (i.e., trib:US=0.03-0.24; Table 2.1) but had considerably different noncarbonate lithology than the mainstem. Montezuma Creek (59.2\%) had lower noncarbonate surficial lithology than the San Juan River (77.8\%; trib:US=0.76), but the other tributaries had higher non-carbonate surficial lithology than the mainstem (trib:US $\geq$ 
1.25; Table 2.1). Four PEIT were identified by dam storage density but not watershed area. These tributaries were small compared to the mainstem (trib:US watershed area $\leq$ 0.06 ) and typically had lower dam storage density than the mainstem (i.e., trib:US dam storage density $\leq 0.15$; Table 2.1 ). However, dam storage density of the Osage River was 4.5 times greater than that the mainstem Missouri River (i.e., trib:US dam storage density $=4.5$; Table 2.1).

Effects of Potentially Ecologically Important Tributaries on Fish Assemblage Structure

We evaluated the effects of PEIT on fish assemblage structure for three Missouri River tributaries: Niobrara River ( $\mathrm{n}=110$ mini-fyke net samples), Platte River ( $\mathrm{n}=50$ mini-fyke samples) and Osage River ( $\mathrm{n}=57$ mini-fyke net samples). We did not evaluate the effects of the Big Sioux or Kansas Rivers ( $\mathrm{n}=26$ mini-fyke net samples each) because there was insufficient fish sampling data adjacent to these confluences. We evaluated the effects of PEIT on fish assemblage structure for two Colorado River tributaries: Sagers Wash ( $\mathrm{n}=68$ seine samples) and the Dolores River ( $\mathrm{n}=61$ seine samples). We did not evaluate the effects of the Green ( $n=0$ seine samples downstream of confluence) or San Juan Rivers ( $\mathrm{n}=0$ seine samples). We evaluated the effects of the White River ( $\mathrm{n}=137$ seine samples) on fish assemblage structure of the Green River but did not evaluate the effects of Vermillion Creek ( $\mathrm{n}=0$ seine samples), the Yampa River ( $\mathrm{n}=0$ seine samples), or Willow Creek ( $\mathrm{n}=2$ seine samples upstream of confluence). We evaluated the effects of the Mancos River ( $\mathrm{n}=61$ seine samples), Montezuma Creek ( $\mathrm{n}=119$ seine samples), and Chinle Creek ( $\mathrm{n}=112$ seine samples) on fish assemblage structure of the San Juan River. 
A total of 45 species were caught in the Missouri River within $5 \mathrm{rkm}$ of the Niobrara River confluence (Table 2.2). All 26 species that occurred in $\geq 5 \%$ of samples were caught downstream of the confluence, but 4 species (Orangespotted Sunfish Lepomis humilis, Freshwater Drum Aplodinotus grunniens, Flathead Catfish Pylodictis olivaris, and Bigmouth Buffalo Ictiobus cyprinellus) were not caught upstream of the Niobrara River. Thirty-seven species were caught in the lower Missouri River within 5 rkm the Platte River confluence, and 22 species occurred in $\geq 5 \%$ of samples (Table 2.2). All common species (i.e., occurred in $\geq 5 \%$ of samples) were caught downstream of the confluence, but Orangespotted Sunfish and White Crappie Pomoxis annularis were not caught upstream of the Platte River. Thirty species were caught in the lower Missouri River within $5 \mathrm{rkm}$ of the Osage River confluence. Of the 22 common species caught, 3 (Brook Silverside Labidesthes sicculus, Mimic Shiner Notropis volucellus, and Spotted Bass Micropterus punctulatus) were not caught upstream of the confluence, and 1 species (Common Carp Cyprinus carpio) was not caught downstream of the confluence.

Sixteen species were caught in the Colorado River adjacent to the Sagers Wash (9 common species) and Dolores River confluences (10 common species; Table 2.2). Thirteen species, including seven common species, were caught in the Green River adjacent to the White River confluence (Table 2.2). Ten species were caught in the San Juan River adjacent to the Mancos River (3 common species) and Montezuma Creek (6 common species) confluences, and nine species were caught within $5 \mathrm{rkm}$ of the Chinle Creek confluence (4 common species; Table 2.2). All common species were caught upstream and downstream of each confluence. 
All Missouri River PEITs affected fish assemblage structure, but only half of upper Colorado River basin PEIT affected fish assemblage structure. In the Missouri River, fish assemblages upstream of the Niobrara $(p=0.008)$, Platte $(p=0.019)$, and Osage ( $p=0.001)$ Rivers differed from assemblages immediately downstream of these tributaries. Predictability of fish assemblages (i.e., upstream or downstream of PEIT) was better than random (i.e., $>50 \%$ correct prediction rate) for the Niobrara ( $68 \%$ accurate prediction rate), Platte ( $74 \%$ accurate prediction rate), and Osage ( $77 \%$ accurate prediction rate) Rivers. The proportion of variance in fish assemblage structure explained by the discriminant analysis (i.e., squared canonical correlation) was highest for the Osage River (0.67), followed by the Platte River (0.65), and the Niobrara River (0.39).

In the upper Colorado River Basin, the White River $(p=0.041)$ affected fish assemblage structure of the Green River, but Sagers Wash ( $p=0.086 ; 59 \%$ accurate prediction rate) and Dolores River ( $p=0.091 ; 56 \%$ accurate prediction rate) did not affect fish assemblage structure of the Colorado River. Chinle Creek $(p=0.030)$ and Montezuma Creek $(p<0.001)$ affected fish assemblage structure of the San Juan River, but the Mancos River did not $(p=0.710)$. Assemblage predictability was better than random for the White River (60\% accurate prediction rate), Chinle Creek (56\% accurate prediction rate), and Montezuma Creek ( $60 \%$ accurate prediction rate). The proportion of variance in fish assemblage structure explained by discriminant analysis was lower for upper Colorado River basin PEIT than for Missouri River PEIT: Montezuma Creek=0.18, White River $=0.10$, and Chinle Creek $=0.09$.

In the Missouri River, more species were associated with the downstream assemblage than the upstream assemblage for the Niobrara $(\mathrm{n}=18$ of $26 ; 69 \%)$ and Platte 
River ( $\mathrm{n}=12$ of 22; 55\%) confluences based on discriminant analysis, but more species were associated with the upstream assemblage for the Osage River confluence ( $\mathrm{n}=12$ of $22 ; 55 \%$; Figure 2.4). In the Green River, most species ( $\mathrm{n}=5$ of $8 ; 62 \%$ ) were associated with the assemblage upstream of the White River confluence (Figure 2.5). For the San Juan River, more species ( $\mathrm{n}=3$ of $4 ; 75 \%$ ) were associated with the assemblage upstream of the Chinle Creek confluence than downstream of the confluence; whereas an equal number of species ( $\mathrm{n}=3$ of $6 ; 50 \%)$ were associated with the reaches immediately upstream and downstream of the Montezuma Creek confluence (Figure 2.5).

Of the 14 species that occurred at all three Missouri River confluences, four species (Emerald Shiner Notropis atherinoides, Orangespotted Sunfish, Red Shiner Cyprinella lutrensis, and White Crappie) were associated with the downstream assemblage of all three confluences, while zero species were associated with the upstream assemblage of all three confluences. Of the remaining ten species, discrepancies across tributaries were primarily due to species associations of the Osage River differing from those of the Platte and Niobrara Rivers (n=6; i.e., Black Crappie Pomoxis nigromaculatus, Bluegill Lepomis macrochirus, Common Carp, River Carpsucker Carpiodes carpio, Shortnose Gar Lepisosteus platostomus, and White Bass Morone chrysops; Figure 2.4). Of the four species that occurred at both San Juan River confluences, two were representative of upstream assemblages (i.e., Flannelmouth Sucker Catostomus latipinnis and Speckled Dace Rhinichthys osculus), while two species were inconsistent among confluences (i.e., Channel Catfish Ictalurus punctatus and Red Shiner; Figure 2.5). 
Species representative of the Missouri River fish assemblage upstream of the Niobrara River were mostly cool, clear water species: Rock Bass Ambloplites rupestris, Smallmouth Bass Micropterus dolomieu, Bluntnose Minnow Pimephales notatus, and Walleye Sander vitreus (Figure 2.4). Common Carp, Orangespotted Sunfish, and Bigmouth Buffalo were most representative of the assemblage downstream of the Niobrara River (Figure 2.4). The most representative species of the fish assemblage upstream of the Platte River were Green Sunfish Lepomis cyanellus, Largemouth Bass Micropterus salmoides, and Silver Chub Macrhybopsis storeriana, whereas Sand Shiner Notropis stramineus, White Bass, and Orangespotted Sunfish best characterized the assemblage downstream of the Platte River (Figure 2.4). Freshwater Drum, Common Carp, and Longnose Gar Lepisosteus osseus best described the fish assemblage upstream of the Osage River, while Emerald Shiner, Bluegill, and Mimic Shiner were most indicative of the assemblage downstream of the Osage River (Figure 2.4).

Sand Shiner, Bluehead Sucker Catostomus discobolus, and Common Carp were the species most representative of the Green River fish assemblage upstream of the White River, while Black Crappie and Colorado Pikeminnow Ptychocheilus lucius were the most representative species of the assemblage downstream of the confluence (Figure 2.5). Speckled Dace and Channel Catfish were most representative of the San Juan River fish assemblage upstream of Montezuma Creek, whereas Fathead Minnow Pimephales promelas, Bluehead Sucker, and Red Shiner were most representative of the assemblage downstream of the confluence (Figure 2.5). Finally, Flannelmouth Sucker, Red Shiner, and Speckled Dace were most representative of the San Juan River fish assemblage 
upstream of Chinle Creek, while Channel Catfish was most representative of the assemblage downstream of the confluence (Figure 2.5).

\section{Discussion}

Our study found that watershed characteristics such as surficial lithology and dam storage density, in addition to watershed area, were valuable for identifying tributaries that may affect large river ecosystems. Tributary size is a logical metric for identifying PEIT because it is a primary driver of geomorphic effects at confluences (Rhoads 1987; Benda et al. 2004a, 2004b) and predicts tributaries that function as surrogate mainstem habitat (Pracheil et al. 2013), but half of the PEIT identified in this study were not identified by tributary size (i.e., watershed area). Rather, surficial lithology or dam storage density of PEIT that were not identified by watershed area differed enough from the mainstem to create discontinuities in the longitudinal profile of these characteristics. Additionally, only one PEIT was identified solely by watershed area. This suggests that most large tributaries are often associated with changes in the watershed characteristics (e.g., lithology and impoundment) that determine the tributary inputs (i.e., volume and characteristics of water and sediment) responsible for geomorphological changes at confluences (Vogel et al. 1999; Rice et al. 2001). Consideration of watershed characteristics may also provide valuable insight into the mechanisms responsible for the ecological effects of tributaries on mainstem rivers. For example, the Niobrara River likely reduces the effects of mainstem impoundment on temperature and flow regimes because it is relatively unimpounded compared to the mainstem, but it may not restore some aspects of the sediment regime (e.g., suspended sediment) because it decreased watershed non-carbonate surficial lithology. Rather, the Niobrara River increased 
watershed coarse eolian (mostly sand) surficial lithology and has substantially affected physical habitat in the middle Missouri River by contributing to a large, braided delta upstream of Lewis and Clark Lake (Galat et al. 2005a; Elliot and Jacobson 2006). Conversely, the Osage River increased mainstem dam storage density, suggesting that some tributaries may increase mainstem habitat alteration (e.g., altered temperature, flow, or sediment regimes).

The relative importance of a particular watershed characteristic for identifying PEIT likely differs among mainstem rivers. Half of the Green River PEITs and all three San Juan River PEITs were identified by lithology, but their effects on mainstem noncarbonate surficial lithology were minor $(\leq 2 \%$ change in non-carbonate surficial lithology) and may not be ecologically meaningful. In contrast, Missouri River and Colorado River PEIT identified by surficial lithology created notable discontinuities in the longitudinal profile (1.5-9.2\% change in non-carbonate surficial lithology) and may be more likely to affect mainstem sediment dynamics, physical habitat, and turbidity. Meanwhile, all PEIT identified by dam storage density in our study created obvious discontinuities in the longitudinal profile of dam storage density that may be ecologically meaningful. Except for the Osage River, these tributaries reduced dam storage density and, therefore, may reduce the effects of hydrological alteration on the mainstem.

Numerous large tributaries and tributaries identified as ecologically important in other studies were not identified as PEIT in this study, potentially due to our cutoff for identifying PEIT (i.e., improve $R^{2} \geq 0.05$ ) and their locations within the river basin (e.g., proximity to dams or other tributaries). First, three tributaries of the Green River (i.e., Duchesne, Price and San Rafael Rivers) provide habitat for endangered large river fishes 
(Tyus and Saunders 2001; Bottcher et al. 2013) but were not identified as PEIT in this study. Second, two Missouri River tributaries, the Grand $\left(20.410^{3} \mathrm{~km}^{2} ; 0.02\right.$ size ratio) and James (47.9 $10^{3} \mathrm{~km}^{2} ; 0.07$ size ratio) Rivers, were not identified as PEIT but had larger watersheds than the Big Sioux River (i.e., PEIT identified by dam storage density; $18.510^{3} \mathrm{~km}^{2} ; 0.02$ size ratio). The James River caused visible changes in the three landscape factors ( $\mathrm{rkm}=1,261$; Figure 2.2), but we suspect it was not identified as a PEIT because few stream segments ( $\mathrm{n}=11 ; 23 \mathrm{rkm})$ occurred between Gavins Point Dam and the James River confluence. Meanwhile, the Grand River was likely not identified as a PEIT because it enters the Missouri River near its confluence with the Mississippi River (approximately rkm 394), where few tributaries are likely of sufficient size to affect a river of this size. Third, the Duchesne River (Green River rkm 401; watershed area=9.9 $10^{3} \mathrm{~km}^{2} ; 0.14$ size ratio) was not identified as a PEIT despite visibly increasing dam storage density, and the White River was not identified as a PEIT by dam storage density despite being large (i.e., identified as PEIT by watershed area) and having substantially different dam storage density than the mainstem Green River. These phenomena (Duchesne River not identified as a PEIT and the White River not identified by dam storage density) were likely a result of these confluences being located approximately 3 rkm (6 stream segments) apart. In this scenario, the Duchesne River increased dam storage density, but this increase was almost immediately reduced by the White River. Ultimately, the omission of these tributaries from our identification of PEIT was likely, in part, due to our cutoff for identifying PEIT (i.e., improve $R^{2}$ by $\geq 0.05$ ), and we recommend reducing this threshold (e.g., improve $R^{2}$ by $\geq 0.01$ ) in future research that aims to maximize the number of PEIT identified. These results suggest that it may be 
unwarranted to infer that tributaries that were not identified as PEIT in our study lack ecological importance and highlight that our approach is just one of potentially numerous tools for identifying ecologically important tributaries.

Our study suggests that PEIT more consistently affected small-bodied fish assemblages of the Missouri River than PEIT of the large rivers in the upper Colorado River basin, potentially due to differences in species assemblages between mainstem rivers. All three Missouri River PEIT that we evaluated affected fish assemblage structure, but only three of the six upper Colorado River basin PEIT that we evaluated affected fish assemblage structure. Furthermore, accuracy of assemblage predictions was consistently higher for assemblages adjacent to Missouri River PEIT ( $\geq 68 \%)$ than for assemblages adjacent to upper Colorado River basin PEIT $(\leq 60 \%)$. Species richness was considerably higher in the middle and lower Missouri River ( $\mathrm{n}=22-26$ common species adjacent to PEIT confluences) than in the large rivers of the upper Colorado River basin ( $\mathrm{n}=3-10$ common species adjacent to PEIT confluences). Therefore, our analyses had more potential variables (i.e., species) to use to discriminate between assemblages for the Missouri River compared to the rivers in the upper Colorado River basin. The hypothesis that tributary effects on fish assemblage structure were more easily determined for the Missouri River due to the high species richness is consistent with Baltz et al. (1987) and Capone and Kushlan (1991), who found that discriminant function prediction accuracy increased when more predictor variables were used. Finally, accuracy rates in this study were lower than other studies that used discriminant analysis to evaluate differences in fish assemblages (e.g., > 80\% accuracy; Rodríguez and Lewis Jr. 1997; Gido et al. 2000; 
Herlihy et al. 2006), potentially due to the close proximity of assemblages (i.e., adjacent stream reaches) and the lack of physical barriers between assemblages.

Tributary effects on small-bodied fish assemblage structure likely vary among tributaries, in part, due to differences in mainstem channel morphology. The middle Missouri River is unchannelized, and the Niobrara River affected physical habitat (Galat et al. 2005a; Elliot and Jacobson 2006) and small-bodied fish assemblage structure. The lower Missouri River, however, is highly modified (e.g., channelization, levees, and engineered confluences) resulting in a self-dredging channel (Jacobson and Galat 2006) that likely reduces tributary effects on physical habitat of the lower Missouri River. Therefore, tributaries of the lower Missouri River may have a greater impact on fish assemblage structure due to their effects on streamflow and temperature regimes rather than their effects on physical habitat. A similar situation may exist (i.e., lack of tributary impacts on physical habitat) in the upper Colorado River basin because some reaches of these rivers are high gradient, canyon bound or highly incised (Blinn and Poff 2005) and likely have high capacity to transport tributary sediment.

Hydrological characteristics may result in seasonal effects of tributaries on fish assemblages that vary among tributaries. Tributary effects on mainstem river habitat depend on the quantity and characteristics of the water and sediment the tributary provides (Rice et al. 2001), but these inputs vary seasonally. Streams in the upper Colorado River basin are primarily fed by mountain run-off and, therefore, have flow regimes characterized by high spring flows and low summer flows (Blinn and Poff 2005). These peak spring flows are likely important for spawning adults, whereas summer base flows affect juvenile nursery habitat (Tyus and Saunders 2001). As a result, it is possible 
upper Colorado River basin tributaries did not consistently affect small-bodied fish assemblage structure during summer (evaluated here) due to reduced tributary inputs but have significant ecological effects during spring for adults (e.g., increased water temperature and food availability, resting and feeding areas; Tyus and Karp 1990). Conversely, in the Missouri River basin, the Platte and Niobrara Rivers have significant base-flow resulting from groundwater inputs (Galat et al. 2005b) and, as a result, may have more consistent seasonal effects on total streamflow, water temperature, physical habitat, and fish assemblage structure than tributaries with less base-flow.

Identifying the potential mechanisms responsible for tributary effects on fish assemblage structure is difficult because tributaries often affected multiple watershed characteristics simultaneously, but our approach to identifying PEIT provided some insight into potential mechanisms. The Niobrara and Platte Rivers were identified as PEIT by size, lithology, and dam storage so the mechanisms responsible for differences in fish assemblage structure could be a combination of changes in water temperature, turbidity, physical habitat, or flow characteristics. However, the effects of the Platte River on fish due to changes in physical habitat may be limited by channel engineering to reduce sedimentation in the channelized lower Missouri River. Meanwhile, the Osage River increased mainstem dam storage density, and some species associations were consistent with increased hydrological alteration downstream of the confluence.

Freshwater Drum (among other species) were characteristic of the upstream assemblage, while Spotted Bass, Black Crappie, and Emerald Shiner were characteristic of the downstream assemblage. Unaltered, lotic environments may provide energetic benefits for Freshwater Drum, while habitats impacted by impoundment may be more 
energetically favorable for Black Crappie and Spotted Bass because Rypel and Bayne (2009) found that Freshwater Drum growth and lipid content was higher in lotic habitats than lentic habitats, but Black Crappie and Spotted Bass had higher lipid content (both species) and growth (Spotted Bass only) in lentic habitats. Furthermore, our observation that Emerald Shiners were associated with increased hydrologic alteration downstream of the Osage River was consistent with Bailey and Allum (1962), who indicated that Emerald Shiners were rare in the Missouri River prior to impoundment but have likely increased since impoundment. Finally, speculation of the mechanisms associated with PEIT effects on fish assemblage structure in the Colorado River basin is unwarranted given the low predictive performance of our discriminant analysis (i.e., prediction accuracy rates $\leq 60 \%$; proportion of variance explained $\leq 0.18$ ) for these tributaries.

\section{Conservation Implications}

Tributaries serve multiple ecologically important roles across spatial scales. At the watershed scale, tributaries modify the longitudinal trends in stream ecosystem structure and function proposed by the River Continuum Concept (Vannote et al. 1980; Bruns et al. 1984; Minshall et al. 1985). At intermediate spatial scales, a limited number of tributaries contribute sufficient streamflow and sediment to mainstem rivers to cause considerable shifts in hydrological and geomorphological conditions, and ultimately biotic assemblage composition of rivers (i.e., Link Discontinuity Concept; Rice et al. 2001). Consistent with the Link Discontinuity Concept, we found that a few tributaries created discontinuities in landscape-level environmental data and small-bodied fish assemblage structure, but the effects varied among tributaries. Finally, tributaries provide habitat for (Tyus and Saunders 2001; Bottcher et al. 2013; Pracheil et al. 2013) and affect 
recruitment (e.g., Pracheil et al. 2009) of large river fishes, and create localized areas of increased habitat and biological diversity (Benda et al. 2004b; Fernandes et al. 2004; Kiffney et al. 2006; Rice et al. 2006; Rice et al. 2008) at finer spatial scales.

Our evaluation of longitudinal trends in watershed characteristics was an efficient approach for identifying PEIT. First, the sizes of tributaries identified as PEIT with our approach (0.01-1.69 tributary: mainstem watershed ratio) were consistent with the sizes of tributaries identified as geomorphically significant by Benda et al. (2004a; typically 0.007 to 0.06 tributary: mainstem watershed ratio). Second, numerous PEIT affected fish assemblage structure in this study or were identified as ecologically important in other studies. In the middle Missouri River, the Niobrara River affects physical habitat by creating a braided delta (Elliot and Jacobson 2006), Paddlefish Polyodon spathula recruitment (Pracheil et al. 2009), and small-bodied fish assemblage structure (this study). Additionally, Pegg and Pierce (2002a) suggested that lower Missouri River tributaries (e.g., Osage and Kansas Rivers) ameliorate the effects of impoundment on streamflow variability parameters (e.g., flow per unit area, coefficient of variation of annual flow, flow predictability, flow contingency) based on stream gage data, but did not explicitly evaluate the effects of these tributaries. Conversely, our results suggest that the Osage River increases hydrological alteration of the Missouri River based on watershed dam storage density. Finally, the White and Yampa Rivers (Green River PEITs) were identified as the tributaries of greatest importance to endangered fish recovery in the Green River basin (Tyus and Saunders 2001) and were used to delineate reaches when developing flow and temperature recommendations (Muth et al. 2000). 
Our approach for identifying PEIT may be useful for targeting tributaries for restoration or protection, delineating ecologically relevant sampling reaches, and guiding microchemistry studies. Our results suggest that the Osage River could be targeted for restoration because it increased hydrological alteration (i.e., dam storage density) of the Missouri River. Conversely, the Niobrara, Big Sioux, Platte, and Kansas Rivers could be prioritized for protection against future hydrological alteration because they likely reduce the effects of mainstem Missouri River impoundment. Our approach could also be used to delineate ecologically relevant sampling reaches because sampling units defined by hydrology, geomorphology, or factors that drive riverine productivity (e.g., floodplain connectivity and degree of impoundment) are expected to be particularly valuable for advancing our understanding of large river ecology (Bayley 1995; Johnson et al. 1995). In this context, treatment and control sites for research studies could be selected from within the same landscape factor cluster (i.e., between two PEIT) to minimize environmental variability among sites. Finally, hard-part (i.e., otolith and fin ray) microchemistry is a popular tool for determining environmental history and stock assignment of fishes, but habitats need different water chemistry signatures for this tool to be effective (Pracheil et al. 2014). Water chemistry in riverine ecosystems is primarily driven by watershed characteristics (Douglas 1968; Hynes 1975). For example, Phelps et al. (2012) and Wuellner et al. (2017) indicated that differences in microchemistry among rivers were likely due to differences in watershed geology. Therefore, our approach for identifying PEIT using landscape-scale environmental data may also be used to identify tributaries that likely have distinct water chemistry characteristics or alter mainstem water chemistry. 


\section{References}

Bailey, R. M., and M. O. Allum. 1962. Fishes of South Dakota. University of Michigan, Museum of Zoology, Miscellaneous Publications No. 119, Ann Arbor.

Baltz, D. M., B. Vondracek, L. R. Brown, and P. B. Moyle. 1987. Influence of temperature on microhabitat choice by fishes in a California stream. Transactions of the American Fisheries Society 116:12-20.

Bayley, P. B. 1995. Understanding large river-floodplain ecosystems. Bioscience 45:153158.

Benda, L., K. Andras, D. Miller, and P. Bigelow. 2004a. Confluence effects in rivers: Interactions of basin scale, network geometry, and disturbance. Water Resource Research 40:W05402.

Benda, L., N. L. Poff, D. Miller, T. Dunne, G. Reeves, G. Pess, and M. Pollock. 2004b. The network dynamics hypothesis: How channel networks structure riverine habitats. BioScience 54:413-427.

Blinn, D. W. and N. L. Poff. 2005. Colorado River basin. Pages 483-538 in A. Benke and C. E. Cushing, editors. Rivers of North America. Elsevier, Oxford.

Bottcher, J. L., T. E. Walsworth, G. P. Thiede, P. Budy, and D. W. Speas. 2013. Frequent usage of tributaries by the endangered fishes of the upper Colorado River basin: Observations from the San Rafael River, Utah. North American Journal of Fisheries Management 33:585-594.

Brown, D. J., and T. G. Coon. 1994. Abundance and assemblage structure of fish larvae in the lower Missouri River and its tributaries. Transactions of the American Fisheries Society 123:718-732. 
Bruns, D. A., G. W. Minshall, C. E. Cushing, K. W. Cummins, J. T. Brock, and R. L. Vannote. 1984. Tributaries as modifiers of the river continuum: Analysis by polar ordination and regression models. Archiv für Hydrobiologie 99:208-220.

Capone, T. A., and J. A. Kushland. 1991. Fish community structure in dry-season stream pools. Ecology 72:983-992.

Charlton, R. 2008. Fundamentals of fluvial geomorphology. Routledge, New York.

Cress, J., D. Soller, R. Sayer, P. Comer, and H. Warner. 2010. Terrestrial ecosystems surficial lithology of the conterminous United States: U.S. Geological Survey Scientific Investigations map 3126. Available at http://rmgsc.cr.usgs. gov/outgoing/ecosystems/USdata/lithology_1km.zip. Accessed 11/13/2013.

Douglas, I. 1968. The effects of precipitation chemistry and catchment area lithology on the quality of river water in selected catchments in eastern Australia. Earth Science Journal 2:126-144.

Elliot, C. M. and R. B. Jacobson. 2006. Geomorphic classification and assessment of channel dynamics in the Missouri National Recreational River, South Dakota and Nebraska. U. S. Geological Survey Scientific Investigations Report 2006-5313, $66 \mathrm{p}$.

Fernandes, C. C., J. Podos, and J. G. Lundberg. 2004. Amazonian ecology: tributaries enhance the diversity of electric fishes. Science 305:1960-1962.

Galat, D. L. C. R. Berry, W. M. Gardner, J. C. Hendrickson, G. E. Mestl, G. J. Power, C. Stone, and M. R. Winston. 2005a. Spatiotemporal patterns and changes in Missouri River fishes. Pages 249-291 in J. Rinne, R. M. Hughes, and B. 
Calamusso, editors. Historical changes in large river fish assemblages of the Americas. American Fisheries Society Symposium 45, Bethesda, MD.

Galat, D. L., C. R. Berry Jr., E. J. Peters, and R. G. White. 2005b. Missouri River basin. Pages 427-480 in A. C. Benke and C. E. Cushing, editors. Rivers of North America. Elsevier, Oxford.

Galat, D. L., M. L. Wildhaber, and D. J. Dieterman. 2001. Spatial patterns of physical habitat, volume 2. Population structure and habitat use of benthic fishes along the Missouri and lower Yellowstone Rivers. U. S. Geological Survey, Cooperative Research Units.

Gido, K. B., W. J. Matthews, and W. C. Wolfinbarger. 2000. Long-term changes in a reservoir fish assemblage: Stability in an unpredictable environment. Ecological Applications 10:1517-1529.

Herlihy, A. T., R. M. Hughes, and J. C. Sifneos. 2006. Landscape clusters based on fish assemblages in the conterminous USA and their relationship to existing landscape classifications. Pages 87-112 in R. M. Hughes, L. Wang, and P. W. Seelbach, editors. Landscape influences on stream habitats and biological assemblages. American Fisheries Society, Symposium 48, Bethesda, MD.

Hynes, H. B. N. 1975. The stream and its valley. Verhandlungen der Internationalen Vereinigung für Theoretische und Angewandte Limnologie 19:1-15.

Jacobson, R. B., and D. L. Galat. 2006. Flow and form in rehabilitation of large-river ecosystems: An example from the lower Missouri River. Geomorphology 77:249269. 
Johnson, B. L., W. B. Richardson, and T. J. Naimo. 1995. Past, present, and future concepts in large river ecology. Bioscience 45:134-141.

Kiffney, P. M., C. M. Greene, J. E. Hall, and J. R. Davies. 2006. Tributary streams create spatial discontinuities in habitat, biological productivity, and diversity in mainstem rivers. Canadian Journal of Fisheries and Aquatic Sciences 63:25182530.

Kwak, T. J. and J. T. Peterson. 2007. Community indices, parameters, and comparisons. Pages 677-763 in C. S. Guy and M. L. Brown, editors. Analysis and interpretation of freshwater fisheries data. American Fisheries Society, Bethesda, MD.

Malmqvist, B., and S. Rundle. 2002. Threats to running water ecosystems of the world. Environmental Conservation 29:134-153.

McKay, L., T. Bondelid, T. Dewald, J. Johnston, R. Moore, and A Rea. 2012. NHDPlus version 2: User guide. Available at ftp://ftp.horizon-systems.com/NHDplus/ NHDPlusV21/Documentation/NHDPlusV2_User_Guide.pdf. Accessed $1 / 28 / 2019$.

Minshall, G. W., K. W. Cummins, R. C. Petersen, C. E. Cushing, D. A. Bruns, J. R. Sedell, and R. L. Vannote. 1985. Developments in stream ecosystem theory. Canadian Journal of Fisheries and Aquatic Sciences 42:1045-1055.

Muth, R. T., L. W. Crist, K. E. LaGory, J. W. Hayse, K. R. Bestgen, T. P. Ryan, J. K. Lyons, and R. A. Valdez. 2000. Flow and temperature recommendations for endangered fishes in the Green River downstream of Flaming Gorge Dam. Final report to Upper Colorado River Endangered Fish Recovery Program, Denver, CO. 
Pegg, M. A., and C. L. Pierce. 2002a. Classification of reaches in the Missouri and lower Yellowstone Rivers based on flow characteristics. River Research and Applications 18:31-42.

Pegg, M. A., and C. L. Pierce. 2002b. Fish community structure in the Missouri and lower Yellowstone rivers in relation to flow characteristics. Hydrobiologia 479:155-167.

Phelps, Q. E., G. W. Whitledge, S. J. Tripp, K. T. Smith, J. E. Garvey, D. P. Herzog, D. E. Ostendorf, J. W. Ridings, J. W. Crites, R. A. Hrabik, W. J. Doyle, and T. D. Hill. 2012. Identifying river of origin for age-0 Scaphirhynchus sturgeons in the Missouri and Mississippi rivers using fin ray microchemistry. Canadian Journal of Fisheries and Aquatic Sciences 69:930-941.

Pracheil, B. M., J. D. Hogan, J. D. Lyons, and P. B. McIntyre. 2014. Using hard-part microchemistry to advance conservation and management of North American fishes. Fisheries 39:451-465.

Pracheil, B. M., P. B. McIntyre, and J. D. Lyons. 2013. Enhancing conservation of largeriver biodiversity by accounting for tributaries. Frontiers in Ecology and the Environment 11:124-128.

Pracheil, B. M., M. A. Pegg, and G. E. Mestl. 2009. Tributaries influence recruitment of fish in large rivers. Ecology of Freshwater Fish 18:603-609.

R Core Team. 2015. R: A language and environment for statistical computing. $R$ Foundation for Statistical Computing, Vienna, Austria. Available at http://www. R-project.org/. 
Rhoads, B. L. 1987. Changes in stream channel characteristics at tributary junctions. Physical Geography 8:346-361.

Rice, S. P., R. I. Ferguson, and T. B. Hoey. 2006. Tributaries control of physical heterogeneity and biological diversity at river confluences. Canadian Journal of Fisheries and Aquatic Sciences 63:2553-2566.

Rice, S. P., M. T. Greenwood, and C. B. Joyce, 2001. Tributaries, sediment sources, and the longitudinal organisation of macroinvertebrate fauna along river systems. Canadian Journal of Fisheries and Aquatic Sciences 58:824-840.

Rice, S. P., P. Kiffney, C. Greene, and G. R. Pess. 2008. The ecological importance of tributaries and confluences. Pages 209-242 in S. P. Rice, A. G. Roy, and B. L. Rhoads, editors. River confluences and the fluvial network. John Wiley \& Sons, Ltd, Chichester, United Kingdom.

Rodríguez, M. A., and W. M. Lewis Jr. 1997. Structure of fish assemblages along environmental gradients in floodplain lakes of the Orinoco River. Ecological Monographs 67:109-128.

Rypel, A. L., and D. R. Bayne. 2009. Hydrological habitat preferences of select southeastern USA fishes resilient to river ecosystem fragmentation. Ecohydrology 2:419-427.

Sable, K. A., and Wohl, E. 2006. The relationship of lithology and watershed characteristics to fine sediment deposition in streams of the Oregon Coast Range. Environmental Management 37:659-670.

Soller, D. R., and M. C. Reheis (Compilers). 2004. Surficial materials in the conterminous United States. U. S. Geological Survey Open-file Report 03- 275. 
Tan, P-N, M. Steinbach, and V. Kumar. 2005. Introduction to data mining. AddisonWesley, Boston.

Tyus, H. M., and C. A. Karp. 1990. Spawning and movements of razorback Sucker, Xyrauchen texanus, in the Green River Basin of Colorado and Utah. Southwestern Association of Naturalists 35:427-433

Tyus, H. M., and J. F. Saunders, III. 2001. An evaluation of the role of tributary streams for recovery of endangered fishes in the Upper Colorado River Basin, with recommendations for future recovery actions. Final report submitted to the Upper Colorado Endangered Fish Recovery Program. Project \#101. 121p.

USACE (U.S. Army Corps of Engineers). 2010. National inventory of dams. Washington, D.C.

USEPA (U.S. Environmental Protection Agency). 2005. National hydrography dataset plus - NHDPlus- Strahler order. Available from http://www.horizonsystems.com/nhdplus/strahlerlist.php. Accessed 4-1-2017.

USEPA (U.S. Environmental Protection Agency) and USGS (U.S. Geological Survey). 2005. National hydrography dataset plus - NHDPlus. Available at http://www. horizon-systems.com/NHDPlus/NHDPlusV1_data.php. Accessed 6/28/2013.

USFWS (U.S. Fish and Wildlife Service). 1987. Interagency standardized monitoring program handbook. Grand Junction, CO.

Valdez, R. A., and R. M. Muth. 2005. Ecology and conservation of native fishes in the upper Colorado River basin. Pages 157-205 in J. Rinne, R. M. Hughes, and B. Calamusso, editors. Historical changes in large river fish assemblages of the Americas. American Fisheries Society Symposium 45, Bethesda, MD. 
Vannote, R. L., G. W. Minshall, K. W. Cummins, J. R. Sedell, and C. E. Cushing. 1980. The river continuum concept. Canadian Journal of Fisheries and Aquatic Sciences $37: 130-137$.

Vogel, R. M., I. Wilson, and C. Daly. 1999. Regional regression models of annual streamflow for the United States. Journal of Irrigation and Drainage Engineering $1255: 148-157$

Welker, T. L., and M. R. Drobish (editors). 2016. Missouri River standard operating procedures for fish sampling and data collection, volume 1.8. U.S. Army Corps of Engineers, Omaha District, Yankton, SD.

Welker, T. L., M. R. Drobish, and G. A. Williams (editors). 2016. Pallid Sturgeon population assessment project, guiding document, volume 1.8. U.S. Army Corps of Engineers, Omaha District, Yankton, SD.

Wuellner, M. R., J. D. Grote, and M. J. Fincel. 2017. Spatial and temporal distinction of microelemental signatures of Missouri River tributaries. River Research and Applications 33:632-638. 


\section{Tables}

Table 2.1. Potentially ecologically important tributaries (PEIT) identified by watershed area, dam storage density, or non-carbonate surficial lithology for the Missouri, upper Colorado, Green, and San Juan Rivers. River km (Rkm) of confluences based on NHD stream network, and Colorado River values represent distance upstream of Glen Canyon Dam, AZ. Bold typeface indicates values of characteristics that resulted in PEIT. Watershed characteristic values presented for the mainstem upstream (US) and downstream (DS) of confluence, tributary (Trib), and tributary/upstream of the confluence (Trib:US).

\begin{tabular}{|c|c|c|c|c|c|c|c|c|c|c|c|c|c|c|c|}
\hline \multirow[b]{3}{*}{ River } & & \multirow[b]{3}{*}{$\mathrm{Rkm}$} & \multicolumn{13}{|c|}{ Watershed characteristic } \\
\hline & & & \multirow[b]{2}{*}{$\begin{array}{l}\text { Watershed } \\
\text { characteristic }\end{array}$} & \multicolumn{4}{|c|}{ Watershed area $\left(1,000 \mathrm{~km}^{2}\right)$} & \multicolumn{4}{|c|}{$\begin{array}{c}\text { Non-carbonate surficial } \\
\text { lithology }(\%)\end{array}$} & \multicolumn{4}{|c|}{$\begin{array}{c}\text { Dam storage density } \\
\left(1,000 \mathrm{~m}^{3} / \mathrm{km}^{2}\right)\end{array}$} \\
\hline & & & & US & DS & Trib & $\begin{array}{l}\text { Trib: } \\
\text { US }\end{array}$ & US & DS & Trib & $\begin{array}{l}\text { Trib: } \\
\text { US }\end{array}$ & US & DS & Trib & $\begin{array}{l}\text { Trib: } \\
\text { US }\end{array}$ \\
\hline $\begin{array}{l}\text { Middle } \\
\text { Missouri River }\end{array}$ & Niobrara River & 1,340 & $\begin{array}{l}\text { Area, dam } \\
\text { storage, } \\
\text { lithology }\end{array}$ & 654.3 & 683.9 & 29.6 & 0.05 & 59.0 & $\mathbf{5 7 . 5}$ & 23.8 & 0.40 & 120.9 & 116.1 & 11.3 & 0.1 \\
\hline \multirow{4}{*}{$\begin{array}{l}\text { Lower } \\
\text { Missouri River }\end{array}$} & Big Sioux River & 1,163 & Dam storage & 743.2 & 761.8 & 18.6 & 0.02 & 52.9 & 51.6 & 0.0 & 0.00 & 108.6 & 106.0 & 1.9 & 0.02 \\
\hline & Platte River & 941 & $\begin{array}{l}\text { Area, dam } \\
\text { storage, } \\
\text { lithology }\end{array}$ & 785.7 & 945.5 & 159.8 & 0.20 & 50.0 & 46.5 & 29.5 & 0.59 & 103.3 & 100.2 & 85.2 & 0.82 \\
\hline & Kansas River & 579 & $\begin{array}{l}\text { Area, } \\
\text { lithology }\end{array}$ & 980.7 & $1,128.9$ & 148.2 & 0.15 & 45.1 & 41.2 & 15.5 & 0.34 & 97.5 & 97.7 & 99.1 & 1.02 \\
\hline & Osage River & 204 & Dam storage & $1,177.8$ & $1,216.6$ & 38.8 & 0.03 & 40.3 & 40.9 & 60.0 & 1.49 & 95.4 & 106.1 & 430.3 & 4.51 \\
\hline \multirow[t]{4}{*}{ Colorado River } & Sagers Wash & 456 & Dam storage & 49.1 & 49.8 & 0.6 & 0.01 & 57.0 & 57.3 & 83.0 & 1.46 & 93.0 & 91.8 & 0.0 & 0.00 \\
\hline & Dolores River & 452 & Lithology & 49.8 & 61.8 & 12.0 & 0.24 & 57.3 & 63.6 & 90.0 & 1.57 & 91.8 & 88.2 & 73.3 & 0.80 \\
\hline & Green River & 295 & $\begin{array}{l}\text { Area, dam } \\
\text { storage, } \\
\text { lithology }\end{array}$ & 67.7 & 182.1 & 114.4 & 1.69 & 63.9 & 73.2 & 78.6 & 1.23 & 80.7 & 74.0 & 70.0 & 0.87 \\
\hline & San Juan River & 80 & $\begin{array}{l}\text { Area, dam } \\
\text { storage }\end{array}$ & 205.9 & 268.8 & 62.9 & 0.31 & 73.2 & 73.3 & 73.7 & 1.01 & 65.7 & 56.5 & 26.4 & 0.40 \\
\hline
\end{tabular}




\begin{tabular}{|c|c|c|c|c|c|c|c|c|c|c|c|c|c|c|c|}
\hline \multirow[b]{3}{*}{ River } & \multirow[b]{3}{*}{ Tributary } & \multirow[b]{3}{*}{$\mathrm{Rkm}$} & \multirow[b]{3}{*}{$\begin{array}{l}\text { Watershed } \\
\text { characteristic }\end{array}$} & \multicolumn{8}{|c|}{ Watershed characteristic } & & & & \\
\hline & & & & \multicolumn{4}{|c|}{ Watershed area $\left(1,000 \mathrm{~km}^{2}\right)$} & \multicolumn{4}{|c|}{$\begin{array}{c}\text { Non-carbonate surficial } \\
\text { lithology }(\%)\end{array}$} & \multicolumn{4}{|c|}{$\begin{array}{c}\text { Dam storage density } \\
\left(1,000 \mathrm{~m}^{3} / \mathrm{km}^{2}\right)\end{array}$} \\
\hline & & & & US & DS & Trib & $\begin{array}{l}\text { Trib: } \\
\text { US }\end{array}$ & US & DS & Trib & $\begin{array}{l}\text { Trib: } \\
\text { US }\end{array}$ & US & DS & Trib & $\begin{array}{l}\text { Trib: } \\
\text { US }\end{array}$ \\
\hline \multirow[t]{4}{*}{ Green River } & $\begin{array}{l}\text { Vermillion } \\
\text { Creek }\end{array}$ & 592 & Lithology & 40.0 & 42.6 & 2.5 & 0.06 & 73.3 & 74.5 & 93.3 & 1.27 & 132.3 & 124.5 & 0.4 & 0.00 \\
\hline & Yampa River & 558 & $\begin{array}{l}\text { Area, dam } \\
\text { storage }\end{array}$ & 43.1 & 64.3 & 21.2 & 0.49 & 74.7 & 76.2 & 79.3 & 1.06 & 122.9 & 86.5 & 12.4 & 0.10 \\
\hline & White River & 398 & $\begin{array}{l}\text { Area, } \\
\text { lithology }\end{array}$ & 78.3 & 91.1 & 12.8 & 0.16 & 74.9 & 76.8 & 89.0 & 1.19 & 97.6 & 84.7 & 6.0 & 0.06 \\
\hline & Willow Creek & 387 & Lithology & 92.0 & 94.5 & 2.4 & 0.03 & 77.0 & 77.5 & 98.3 & 1.28 & 83.9 & 81.8 & 0.0 & 0.00 \\
\hline \multirow[t]{3}{*}{ San Juan River } & Mancos River & 307 & $\begin{array}{l}\text { Dam storage, } \\
\text { lithology }\end{array}$ & 35.1 & 37.2 & 2.1 & 0.06 & 76.9 & 78.0 & 95.9 & 1.25 & 44.8 & 42.7 & 6.5 & 0.15 \\
\hline & $\begin{array}{l}\text { Montezuma } \\
\text { Creek }\end{array}$ & 251 & Lithology & 40.6 & 43.6 & 3.0 & 0.07 & 77.8 & 76.5 & 59.2 & 0.76 & 40.0 & 37.4 & 2.2 & 0.05 \\
\hline & Chinle Creek & 208 & $\begin{array}{l}\text { Area, dam } \\
\text { storage, } \\
\text { lithology }\end{array}$ & 47.0 & $\mathbf{5 7 . 0}$ & 10.0 & 0.21 & 75.8 & 73.8 & 64.1 & 0.85 & 35.3 & 29.1 & 0.0 & 0.00 \\
\hline
\end{tabular}


Table 2.2. Percent of samples that each fish species occurred within 5 river km of potentially ecologically important tributary confluences in the Missouri (from 2005 to 2013), upper Colorado, Green, and San Juan Rivers (from 1990 to 2012). Bold typeface indicates species that occurred in $\geq 5 \%$ of samples and were used in discriminant analyses.

\begin{tabular}{|c|c|c|c|c|c|c|c|c|c|c|}
\hline \multirow[b]{2}{*}{ Common name } & \multirow[b]{2}{*}{ Scientific name } & \multicolumn{3}{|c|}{ Missouri River } & \multicolumn{2}{|c|}{ Colorado River } & \multirow{2}{*}{$\begin{array}{l}\text { Green River } \\
\text { White River }\end{array}$} & \multicolumn{3}{|c|}{ San Juan River } \\
\hline & & $\begin{array}{l}\text { Niobrara } \\
\text { River }\end{array}$ & $\begin{array}{l}\text { Platte } \\
\text { River }\end{array}$ & $\begin{array}{l}\text { Osage } \\
\text { River }\end{array}$ & $\begin{array}{l}\text { Sagers } \\
\text { Wash }\end{array}$ & $\begin{array}{l}\text { Dolores } \\
\text { River }\end{array}$ & & $\begin{array}{l}\text { Mancos } \\
\text { River }\end{array}$ & $\begin{array}{l}\text { Montezuma } \\
\text { Creek }\end{array}$ & $\begin{array}{l}\text { Chinle } \\
\text { Creek }\end{array}$ \\
\hline Bigmouth Buffalo & Ictiobus cyprinellus & 9.1 & 4.0 & & & & & & & \\
\hline Bigmouth Shiner & Notropis dorsalis & 0.9 & & & & & & & & \\
\hline Black Bullhead & Ameiurus melas & 1.8 & & & & 3.3 & 1.5 & 3.3 & & \\
\hline Black Crappie & $\begin{array}{l}\text { Pomoxis } \\
\text { nigromaculatus }\end{array}$ & 20.0 & 10.0 & 10.5 & & & 14.6 & & & \\
\hline Bluegill & Lepomis macrochirus & 30.0 & 50.0 & 22.8 & & & & & & \\
\hline Bluehead Sucker & Catostomus discobolus & & & & 16.2 & 14.8 & 8.8 & 1.6 & 7.6 & 2.7 \\
\hline Bluntnose Minnow & Pimephales notatus & 30.0 & & 14.0 & & & & & & \\
\hline Bonytail Chub & Gila elegans & & & & & & & & & \\
\hline Brassy Minnow & $\begin{array}{l}\text { Hybognathus } \\
\text { hankinsoni }\end{array}$ & 2.7 & & & & & & & & \\
\hline Brook Silverside & Labidesthes sicculus & & 26.0 & 5.3 & & & & & & \\
\hline Bullhead Minnow & Pimephales vigilax & & & 35.1 & & & & & & \\
\hline Burbot & Lota lota & 0.9 & & & & & & & & \\
\hline Channel Catfish & Ictalurus punctatus & 14.5 & 50.0 & 28.1 & 2.9 & & 0.7 & 50.8 & 57.1 & 61.6 \\
\hline $\begin{array}{l}\text { Colorado } \\
\text { Pikeminnow }\end{array}$ & Ptychocheilus lucius & & & & 4.4 & 8.2 & 14.6 & 1.6 & 3.4 & 0.9 \\
\hline Common Carp & Cyprinus carpio & 21.8 & 10.0 & 7.0 & 7.4 & 8.2 & 13.1 & & 0.8 & \\
\hline Creek Chub & Semotilus atromaculatus & 1.8 & 2.0 & & & & & & & \\
\hline Emerald Shiner & Notropis atherinoides & 35.5 & 68.0 & 38.6 & & & & & & \\
\hline Fathead Minnow & Pimephales promelas & 3.6 & 26.0 & 1.8 & 57.4 & 57.4 & 28.5 & 4.9 & 17.6 & 2.7 \\
\hline $\begin{array}{l}\text { Flannelmouth } \\
\text { Sucker }\end{array}$ & Catostomus latipinnis & & & & 7.4 & 9.8 & 4.4 & 4.9 & 25.2 & 6.3 \\
\hline
\end{tabular}




\begin{tabular}{|c|c|c|c|c|c|c|c|c|c|c|}
\hline \multirow[b]{2}{*}{ Common name } & \multirow[b]{2}{*}{ Scientific name } & \multicolumn{3}{|c|}{ Missouri River } & \multicolumn{2}{|c|}{ Colorado River } & \multirow{2}{*}{$\begin{array}{l}\text { Green River } \\
\text { White River }\end{array}$} & \multicolumn{3}{|c|}{ San Juan River } \\
\hline & & $\begin{array}{c}\text { Niobrara } \\
\text { River }\end{array}$ & $\begin{array}{l}\text { Platte } \\
\text { River }\end{array}$ & $\begin{array}{l}\text { Osage } \\
\text { River }\end{array}$ & $\begin{array}{l}\text { Sagers } \\
\text { Wash }\end{array}$ & $\begin{array}{c}\text { Dolores } \\
\text { River }\end{array}$ & & $\begin{array}{c}\text { Mancos } \\
\text { River }\end{array}$ & $\begin{array}{l}\text { Montezuma } \\
\text { Creek }\end{array}$ & $\begin{array}{l}\text { Chinle } \\
\text { Creek }\end{array}$ \\
\hline Flathead Catfish & Pylodictis olivaris & 5.5 & 2.0 & 3.5 & & & & & & \\
\hline Flathead Chub & Platygobio gracilis & 0.9 & & & & & & & & \\
\hline Freshwater Drum & Aplodinotus grunniens & 7.3 & 62.0 & 52.6 & & & & & & \\
\hline Gizzard Shad & Dorosoma cepedianum & 11.8 & 54.0 & 29.8 & & & & & & \\
\hline Goldeye & Hiodon alosoides & & & 3.5 & & & & & & \\
\hline Goldfish & Carassius auratus & & 2.0 & & & & & & & \\
\hline Grass Carp & $\begin{array}{l}\text { Ctenopharyngodon } \\
\text { idella }\end{array}$ & & 2.0 & 1.8 & & & & & & \\
\hline Grass Pickerel & $\begin{array}{l}\text { Esox americanus } \\
\text { vermiculatus }\end{array}$ & 4.5 & & & & & & & & \\
\hline Green Sunfish & Lepomis cyanellus & 17.3 & 22.0 & 7.0 & 2.9 & 9.8 & 4.4 & & & \\
\hline Humpback Chub & Gila cypha & & & & & & & & & \\
\hline Johnny Darter & Etheostoma nigrum & 13.6 & & & & & & & & \\
\hline Largemouth Bass & Micropterus salmoides & 19.1 & 10.0 & & 4.4 & 4.9 & & & & \\
\hline Longnose Gar & Lepisosteus osseus & & 16.0 & 21.1 & & & & & & \\
\hline Mimic Shiner & Notropis volucellus & & & 7.0 & & & & & & \\
\hline Northern Pike & Esox lucius & 4.5 & & & & & & & & \\
\hline $\begin{array}{l}\text { Orangespotted } \\
\text { Sunfish }\end{array}$ & Lepomis humilis & 9.1 & 12.0 & 12.3 & & & & & & \\
\hline Plains Killifish & Fundulus zebrinus & & & & 10.3 & 13.1 & & & 3.4 & 0.9 \\
\hline Plains Minnow & Hybognathus placitus & 0.9 & 2.0 & & & & & & & \\
\hline Plains Topminnow & Fundulus sciadicus & & 2.0 & & & & & & & \\
\hline Pumpkinseed & Lepomis gibbosus & 0.9 & & & & & & & & \\
\hline
\end{tabular}




\begin{tabular}{|c|c|c|c|c|c|c|c|c|c|c|}
\hline \multirow[b]{2}{*}{ Common name } & \multirow[b]{2}{*}{ Scientific name } & \multicolumn{3}{|c|}{ Missouri River } & \multicolumn{2}{|c|}{ Colorado River } & \multirow{2}{*}{$\begin{array}{l}\text { Green River } \\
\text { White River }\end{array}$} & \multicolumn{3}{|c|}{ San Juan River } \\
\hline & & $\begin{array}{c}\text { Niobrara } \\
\text { River }\end{array}$ & $\begin{array}{l}\text { Platte } \\
\text { River }\end{array}$ & $\begin{array}{l}\text { Osage } \\
\text { River }\end{array}$ & $\begin{array}{l}\text { Sagers } \\
\text { Wash }\end{array}$ & $\begin{array}{l}\text { Dolores } \\
\text { River }\end{array}$ & & $\begin{array}{l}\text { Mancos } \\
\text { River }\end{array}$ & $\begin{array}{l}\text { Montezuma } \\
\text { Creek }\end{array}$ & $\begin{array}{l}\text { Chinle } \\
\text { Creek }\end{array}$ \\
\hline Quillback & Carpiodes cyprinus & 0.9 & 2.0 & & & & & & & \\
\hline Rainbow Smelt & Osmerus mordax & 0.9 & & 1.8 & & & & & & \\
\hline Razorback Sucker & Xyrauchen texanus & & & & 1.5 & 1.6 & & & & \\
\hline Red Shiner & Cyprinella lutrensis & 20.0 & 76.0 & 61.4 & 58.8 & 57.4 & 38.0 & 41.0 & 52.1 & 41.1 \\
\hline Redside Shiner & Richardsonius balteatus & & & & & & & & & \\
\hline River Carpsucker & Carpiodes carpio & 26.4 & 14.0 & 8.8 & & & & & & \\
\hline River Shiner & Notropis blennius & & 78.0 & 3.5 & & & & & & \\
\hline Rock Bass & Ambloplites rupestris & 10.0 & & & & & & & & \\
\hline Roundtail Chub & Gila robusta & & & & 2.9 & 1.6 & & & & \\
\hline Sand Shiner & Notropis stramineus & 24.5 & 36.0 & & 42.6 & 52.5 & 29.9 & & & \\
\hline Sauger & Sander canadense & 4.5 & & 3.5 & & & & & & \\
\hline Shoal Chub & Macrhybopsis aestivalis & & 2.0 & 3.5 & & & & & & \\
\hline $\begin{array}{l}\text { Shorthead } \\
\text { Redhorse }\end{array}$ & $\begin{array}{l}\text { Moxostoma } \\
\text { macrolepidotum }\end{array}$ & 8.2 & 2.0 & & & & & & & \\
\hline Shortnose Gar & Lepisosteus platostomus & 34.5 & 36.0 & 33.3 & & & & & & \\
\hline Sicklefin Chub & Macrhybopsis meeki & & 2.0 & & & & & & & \\
\hline Silver Chub & Macrhybopsis storeriana & 2.7 & 60.0 & 7.0 & & & & & & \\
\hline Smallmouth Bass & Micropterus dolomieu & 40.0 & 4.0 & & & & & & & \\
\hline $\begin{array}{l}\text { Smallmouth } \\
\text { Buffalo }\end{array}$ & Ictiobus bubalus & 1.8 & 54.0 & & & & & & & \\
\hline Speckled Dace & Rhinichthys osculus & & & & 7.4 & 3.3 & 2.2 & 50.8 & 62.2 & 34.8 \\
\hline Spotfin Shiner & Cyprinella spiloptera & 69.1 & 4.0 & & & & & & & \\
\hline
\end{tabular}




\begin{tabular}{|c|c|c|c|c|c|c|c|c|c|c|}
\hline \multirow[b]{2}{*}{ Common name } & \multirow[b]{2}{*}{ Scientific name } & \multicolumn{3}{|c|}{ Missouri River } & \multicolumn{2}{|c|}{ Colorado River } & \multirow{2}{*}{$\begin{array}{l}\text { Green River } \\
\text { White River }\end{array}$} & \multicolumn{3}{|c|}{ San Juan River } \\
\hline & & $\begin{array}{c}\text { Niobrara } \\
\text { River }\end{array}$ & $\begin{array}{l}\text { Platte } \\
\text { River }\end{array}$ & $\begin{array}{l}\text { Osage } \\
\text { River }\end{array}$ & $\begin{array}{l}\text { Sagers } \\
\text { Wash }\end{array}$ & $\begin{array}{c}\text { Dolores } \\
\text { River }\end{array}$ & & $\begin{array}{c}\text { Mancos } \\
\text { River }\end{array}$ & $\begin{array}{c}\text { Montezuma } \\
\text { Creek }\end{array}$ & $\begin{array}{l}\text { Chinle } \\
\text { Creek }\end{array}$ \\
\hline Spottail Shiner & Notropis hudsonius & 14.5 & & & & & & & & \\
\hline Spotted Bass & Micropterus punctulatus & & & 5.3 & & & & & & \\
\hline Stonecat & Noturus flavus & 0.9 & & & & & & & & \\
\hline Walleye & Sander vitreus & 6.4 & 2.0 & & & & & & & \\
\hline $\begin{array}{l}\text { Western } \\
\text { Mosquitofish }\end{array}$ & Gambusia affinis & & 4.0 & 10.5 & 7.4 & 3.3 & & 3.3 & 4.2 & 0.9 \\
\hline $\begin{array}{l}\text { Western Silvery } \\
\text { Minnow }\end{array}$ & Hybognathus argyritis & 0.9 & & & & & & & & \\
\hline White Bass & Morone chrysops & 10.9 & 52.0 & 19.3 & & & & & & \\
\hline White Crappie & Pomoxis annularis & 15.5 & 6.0 & 12.3 & & & & & & \\
\hline White Sucker & $\begin{array}{l}\text { Catostomus } \\
\text { commersonii }\end{array}$ & & & & 4.4 & 8.2 & 0.7 & & & \\
\hline Yellow Bullhead & Ameiurus natalis & & & & & & & 1.6 & & \\
\hline Yellow Perch & Perca flavescens & 3.6 & & & & & & & & \\
\hline
\end{tabular}




\section{Figures}

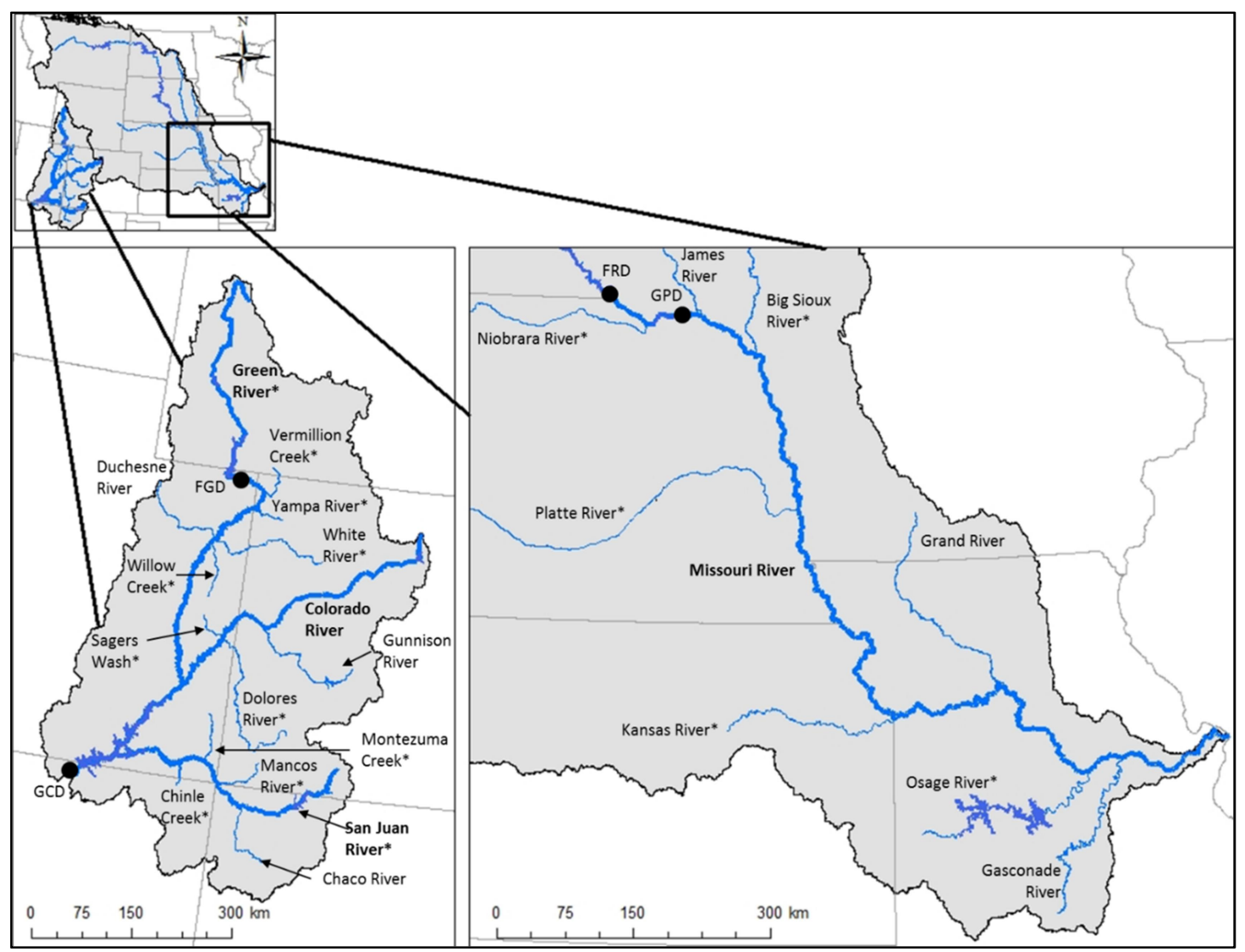

Figure 2.1. Middle and lower Missouri River (right), and upper Colorado, Green, and San Juan Rivers (left) and subset of their tributaries. FRD=Fort Randall Dam, SD; GPD=Gavins Point Dam, NE-SD; FGD=Flaming Gorge Dam, UT; GCD=Glen Canyon Dam, AZ. Asterisks (*) indicate potentially ecologically important tributaries identified in this study, black dots $(\bullet)$ represent mainstem dams. 

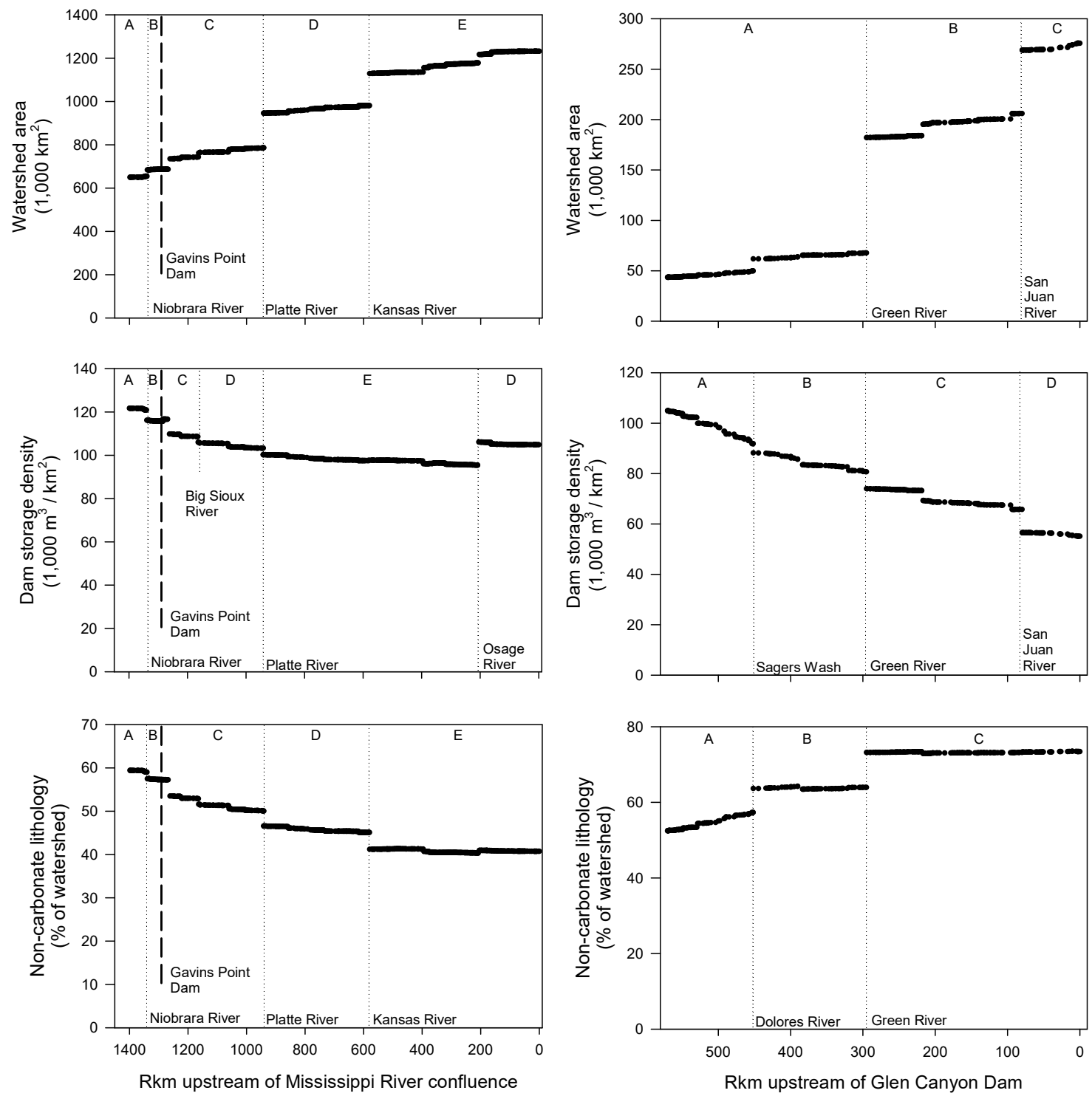

Figure 2.2. Longitudinal profile of watershed characteristics of the Missouri River downstream of Fort Randall Dam, SD (left) and the Colorado River from the Gunnison River to Glen Canyon Dam, AZ. Dotted lines indicate locations of potentially ecologically important tributaries. Dashed line represents location of Gavins Point Dam, NE-SD. Rkm=river kilometer. Letter designations ("A" - "E") represent cluster designations from $k$-means clustering analysis. Values of rkm based on NHD stream network. 

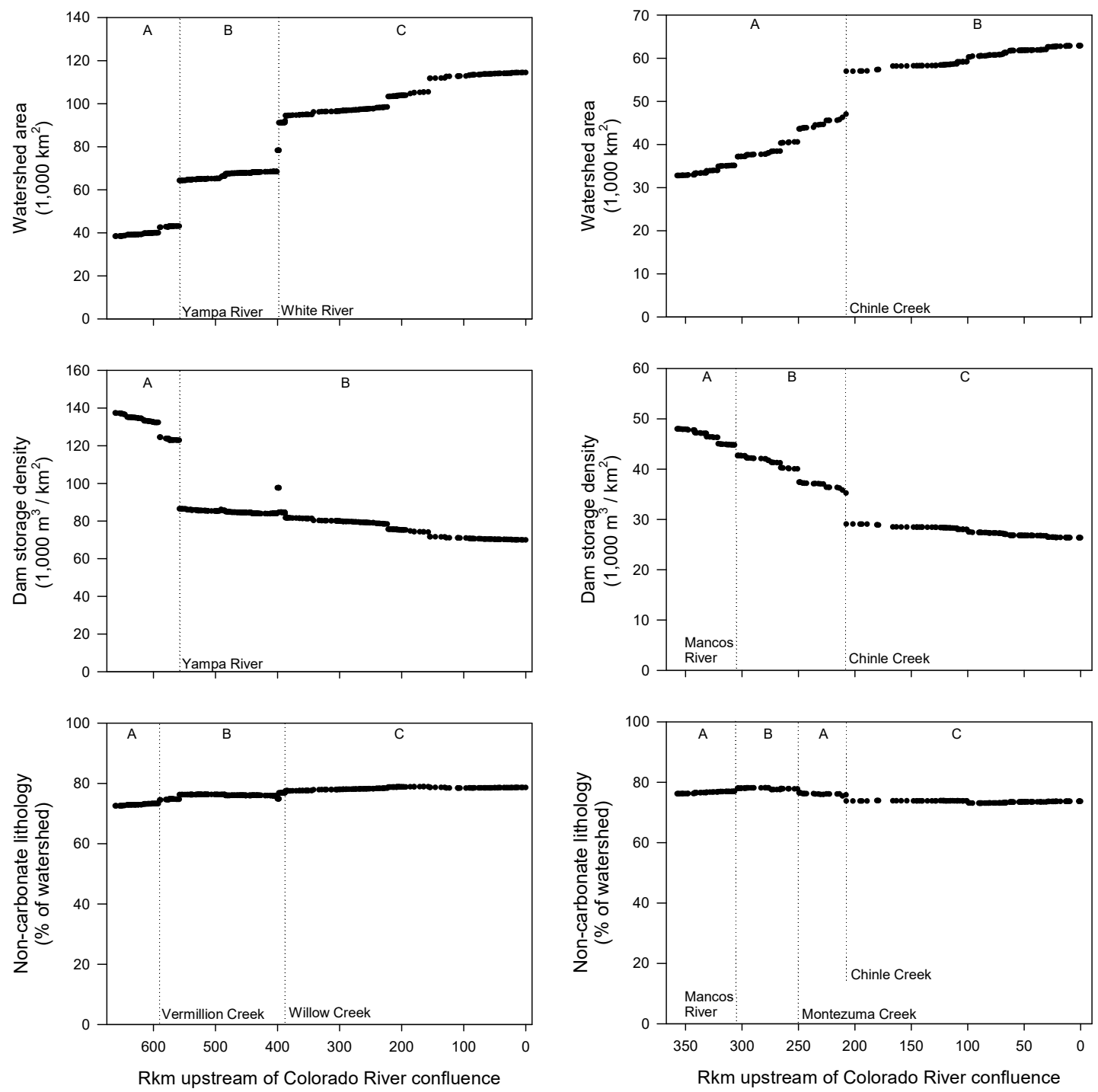

Figure 2.3. Longitudinal profile of watershed characteristics of the Green River downstream of Flaming Gorge Dam, UT (left), and the San Juan River downstream of the Chaco River (right). Dotted lines indicate locations of potentially ecologically important tributaries. $\mathrm{Rkm}=$ river kilometer. Letter designations ("A" - "C") represent cluster designations from $k$-means clustering analysis. Values of rkm based on NHD stream network. 


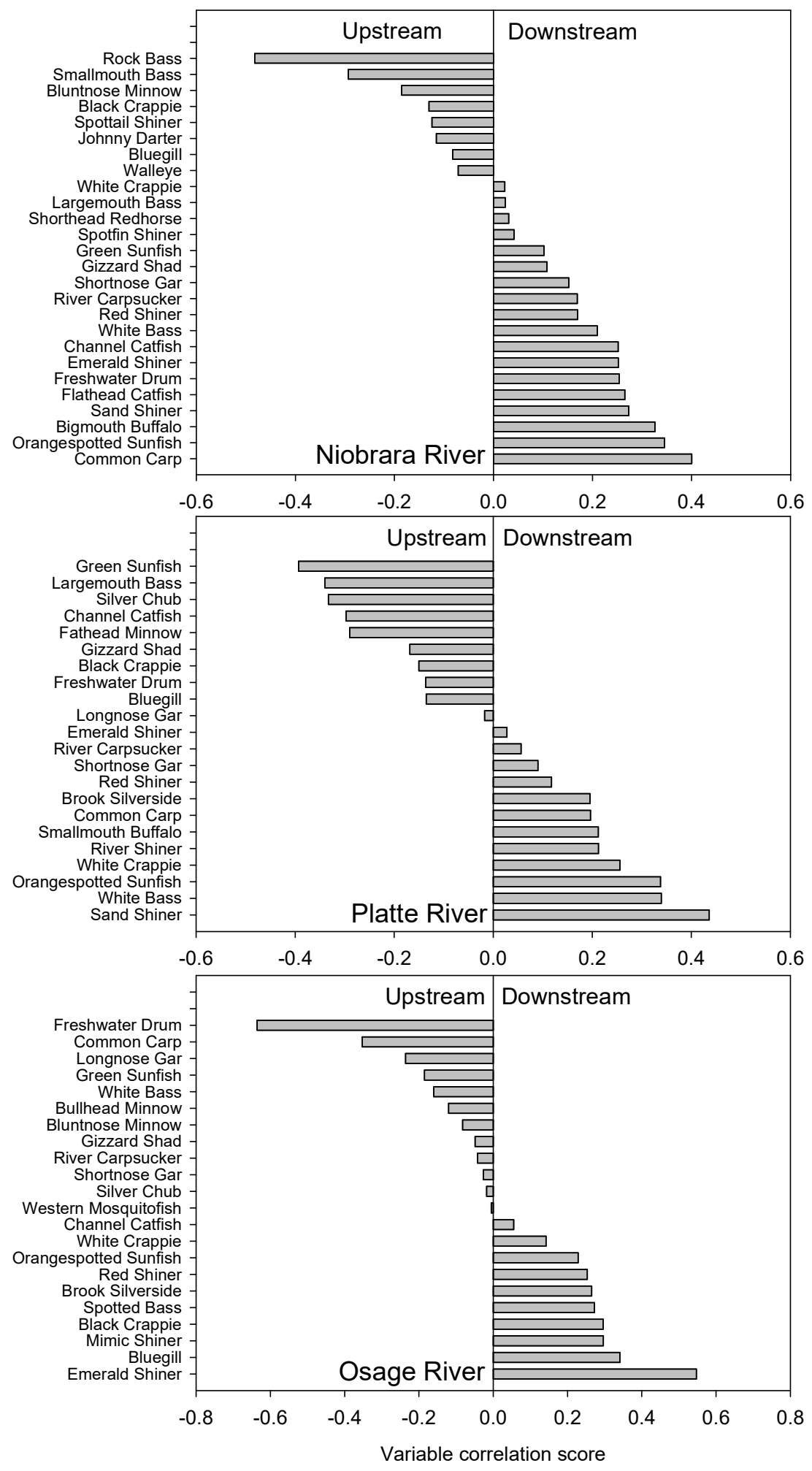

Figure 2.4. Discriminant analysis variable correlation scores for differentiating assemblages upstream (negative) and downstream (positive) of potentially ecologically important Missouri River tributaries: Niobrara (top), Platte (middle), and Osage Rivers (bottom). 

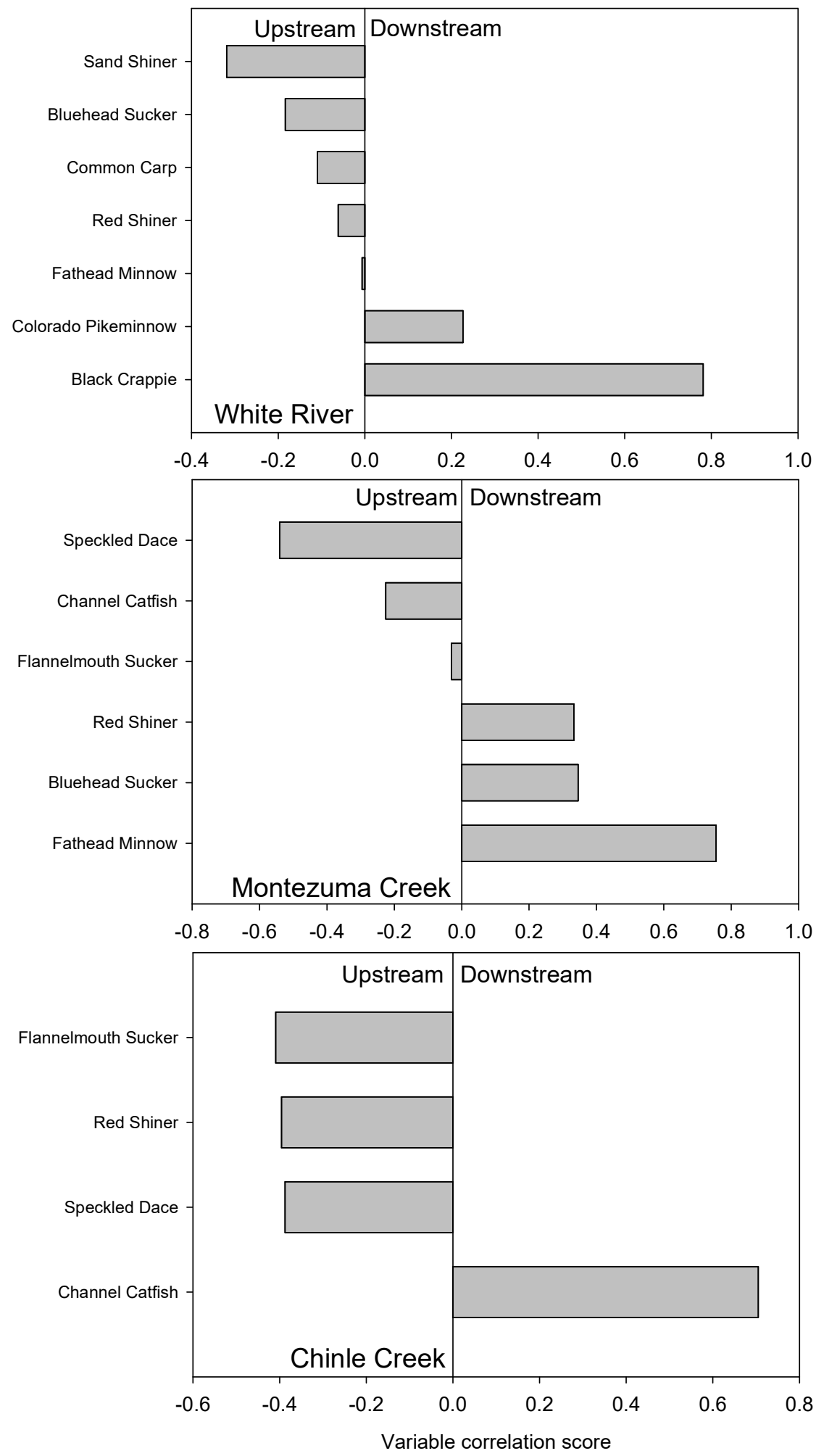

Figure 2.5. Discriminant analysis variable correlation scores for differentiating assemblages upstream (negative) and downstream (positive) of potentially ecologically important tributaries of the Green (i.e., White River; top) and San Juan Rivers [i.e., Montezuma Creek (middle), and Chinle Creek (bottom)]. 


\title{
CHAPTER 3- TRANSFERABILITY OF SPECIES DISTRIBUTION MODELS OF LOTIC FISHES ACROSS RIVER BASINS
}

\begin{abstract}
Species distribution models (SDMs) are commonly applied to new areas to predict non-native fish species establishment and target areas for prevention measures. Currently, however, it is unclear if the ability of SDMs to effectively transfer to new areas (i.e., transferability) is predictable based on species characteristics. Therefore, we quantified transferability of fish SDMs from the Missouri River basin (MRB) to the Colorado River basin (CRB) for 25 species, evaluated the effects of species characteristics (i.e., family, nativity, temperature and substrate preference, reproductive guild, and trophic feeding guild) on SDM transferability, and compared SDMs among basins to examine patterns in SDM transferability. We developed SDMs for fishes occurring in $1^{\text {st }}$ to $4^{\text {th }}$ order streams using multivariate adaptive regression splines, landscape-level environmental data, and recent (1990-2012) fish sampling records. Species distribution models developed for MRB data had reasonable transferability to the CRB [area under the receiver operator curve (AUC) $\geq 0.7$ ] for 15 of 25 species. Family, CRB nativity, temperature and substrate preferences, reproductive guild and trophic feeding guild were not significant predictors of transferability (i.e., AUC; $p=0.65$ ) but there was evidence of greater transferability for species with more specialized feeding strategies than generalist feeding strategies when we limited our analysis to groups with at least three species (one-way ANOVA $p=0.02$ ). Species distribution models developed for the MRB that transferred effectively to the CRB generally contained variables that
\end{abstract}


explained more variability (i.e., greater delta deviance) in CRB SDMs than those that did not transfer effectively. Transferability was generally not predictable based on species characteristics, re-enforcing the hypothesis that transferability is species- and contextspecific. This finding highlights the need to use caution when transferring SDMs temporally or spatially, and the need to evaluate transferability when interpreting SDM predictions related to species introductions and climate change.

\section{Introduction}

Understanding the factors that affect the ability of species distribution models (SDMs) to transfer in time and space (i.e., transferability) is important for predicting the effects of climate change on species distributions and potential distributions of non-native species. Species distribution models describe relationships between environmental data and species occurrence or abundance (Elith and Leathwick 2009) and can be valuable tools for predicting changes in distributions due to climate change and potential nonnative species invasions (Olden and Jackson 2002; Peterson 2003; Guisan and Thuiller 2005). However, evaluating model transferability is a particularly important component of model evaluation when SDMs are to be projected to new datasets (e.g., in time or space) because the utility of these predictions depends on adequate transferability (Randin et al. 2006; Wenger and Olden 2012; Huang and Frimpong 2016).

Transferability of SDMs is particularly important for informing conservation efforts of lotic fishes threatened by non-native species. Non-native species have negatively affected native fish assemblages, including contributing to the extinction of 27 species in North America (Miller et al. 1989), and their effects on native species have likely increased in the USA in recent years because non-native fish species richness was 
predicted to double from 1990 to 2025 (Malmqvist and Rundle 2002). Management actions that prevent non-native species establishment are typically the most cost-effective options for managing the effects of non-native species (Wittenberg and Cock 2001), and transferring SDMs to new areas can identify areas of potential non-native fish establishment that can be targeted for prevention measures.

Despite the importance of SDM transferability to freshwater fish conservation and recent emphasis on SDM transferability (Wenger and Olden 2012; Huang and Frimpong 2016), the factors affecting transferability of lotic fish SDMs are relatively unclear. Yates et al. (2018) indicated that determining whether transferability was trait- or taxon-specific was one of the fundamental conceptual challenges in the study of ecological model transferability and, if addressed, could improve confidence in predictions from ecological models. Furthermore, multiple biotic factors were identified as potentially affecting SDM transferability in other taxa (e.g., ecological traits and trait plasticity, the equilibrium status of the species with its environment, prevalence of the species, and changes in biotic interactions over time or space; Elith and Leathwick 2009; Soininen and Luoto 2014; Huang and Frimpong 2016), but the effects of species characteristics (e.g., taxonomy and traits) on SDM transferability have not been examined thoroughly for lotic fishes.

To improve our understanding of lotic fish SDM transferability, we quantified transferability of fish distribution models from two adjacent but distinct basins in North America: the Missouri River basin (MRB) to the Colorado River basin (CRB). We also evaluated the effects of a variety of species characteristics on SDM transferability, and compared SDMs among basins to explain patterns in transferability of SDMs. 


\section{Methods}

\section{$\underline{\text { Study Site }}$}

The MRB and CRB provided an ideal opportunity to evaluate spatial transferability of SDMs because many non-native species in the CRB are native to the MRB and, therefore, evaluating the ability of SDMs developed for the MRB to transfer to the CRB simulates a typical application of spatially transferring SDMs to predict nonnative species distributions. The CRB drains approximately $642,000 \mathrm{~km}^{2}$ in the southwestern USA and northwestern Mexico and is composed primarily of semi-arid shrub lands and desert shrubs (Carlson and Muth 1989; Blinn and Poff 2005). There are 36 fish species (including 3 marine or brackish species and 23 endemic species) native to the CRB (Carlson and Muth 1989), but there are approximately 50 non-native species in the upper CRB (Valdez and Muth 2005) and 80 non-native species in the lower CRB (Mueller et al. 2005). The MRB drains approximately $1,371,017 \mathrm{~km}^{2}$ in the USA and $25,100 \mathrm{~km}^{2}$ in Canada and is primarily composed of the semi-arid (32 $\mathrm{cm}$ mean annual precipitation), highly erodible Great Plains (Galat et al. 2005). There are 138 native fish species and 35 non-native fish species in the MRB (Galat et al. 2005).

\section{$\underline{\text { Fish Distribution Data }}$}

We summarized geo-referenced fish occurrence data for small streams $\left(1^{\text {st }}-4^{\text {th }}\right.$ order) in the CRB ( $n=2,830$ segments) and MRB ( $n=3,789$ segments) collected between 1990 and 2012. Occurrence data was a compilation of state and federal agency databases, university and museum collections, and gray literature originally compiled by Annis et al. (2010), Whittier et al. (2011), and Whittier and Sievert (2014). Fish samples were linked to National Hydrography Dataset (NHDPlus version 1; USEPA and USGS 2005) stream 
segments using a spatial join in ArcGIS (ESRI 2009). Stream segments are typically lengths of stream extending between two confluences, but may be shorter if side channels, divergences, or other features occur (McKay et al. 2012). Fish samples were summarized to species presence-absence for each stream segment because effort and gear types varied among data sources and sampling locations. Samples that did not capture any fish were excluded from our analysis. It was unclear if samples were single-species collections or community collections, but two or more species were documented at most stream segments $(71.5 \%)$.

\section{Environmental Data}

We acquired and summarized natural and anthropogenic landscape-level environmental data to serve as predictor variables in SDMs. Many of these predictor variables were or were similar to factors found to affect fish distributions in the CRB and MRB in previous studies (Annis et al. 2010; Strecker et al. 2011; Whitney et al. 2017) and were readily available for the MRB and CRB (Table 3.1). Landscape-level factors were quantified for the stream segment, local catchment ("local"), and upstream network watershed ("network") spatial scales. Natural environmental variables were stream order, base-flow index (percent of streamflow from groundwater), mean annual flow, mean annual velocity, slope, elevation, temperature, precipitation, and surficial lithology. Except for surficial lithology, these datasets were summarized by the data source. We quantified three network-scale surficial lithology (Cress et al. 2010) metrics for each stream segment using the Catchment Attribute Allocation and Accumulation Tool (http://www.horizon-systems.com/nhdplus/NHDPlusV1_tools.php) that represented the dominant lithology types that occur in both the MRB and CRB: percent non-carbonate 
lithology, percent silicic lithology, and percent alluvium and fine-textured coastal zone sediment (Table 3.1). Local catchment and network watershed anthropogenic variables included in models were cultivated crop and urban land uses, number of dams, and population density (Esselman et al. 2011a; Table 3.1). We combined low, medium, and high intensity urban land uses into a total urban land use value.

We identified correlated landscape variables using Spearman's correlation analysis and removed variables that were strongly correlated $\left(r_{s} \geq|0.8|\right)$ with other variables to reduce the effect of collinearity on our analyses (Huang and Frimpong 2016; Whitney et al. 2017). If a metric type (e.g., crop land use) was strongly correlated between spatial scales (e.g., local and network), then we retained the largest spatial scale (e.g., network) for analysis. Mean annual air temperature was highly correlated with elevation $\left(r_{s}=-0.81, p<0.0001\right)$, minimum air temperature $\left(r_{s}=0.99, p<0.0001\right)$, and maximum air temperature $\left(r_{s}=0.99, p<0.0001\right)$, and thus these three variables were removed from further analyses. Local catchment crop land use $\left(r_{s}=0.86, p<0.0001\right)$, urban land use $\left(r_{s}=0.82, p<0.0001\right)$, and population density $\left(r_{s}=0.91, p<0.0001\right)$ were removed from the analysis because they were highly correlated with their network watershed counterparts.

\section{$\underline{\text { Data Analysis }}$}

We developed species distribution models for 25 species that occur both in the $\mathrm{CRB}$ and MRB as a function of landscape-level environmental factors (Table 3.1) using multivariate adaptive regression splines (MARS) in program $\mathrm{R}$ version 3.4.2 (R Core Team 2017). Models were developed using the 'earth' package and incorporated modifications for binomial response variables (Milborrow 2017). We chose this modeling 
approach because MARS models performed well in previous studies in the CRB (Strecker et al. 2011; Whitney et al. 2017), handle non-linear relationships that are common in ecological data, and can be readily transferred to new datasets (Leathwick et al. 2006). We limited our analysis to species that occurred at $\geq 3 \%$ of MRB segments because SDMs created with fewer occurrences performed poorly (Whitney et al. 2017). We created SDMs based on MRB data to evaluate transferability because most species $(\mathrm{n}=17$ of 25$)$ that occurred in both basins were native to the MRB and non-native to the CRB. Therefore, this approach best represented the application of SDM transferability for predicting non-native species distributions. Finally, we created SDMs based on CRB data to verify that the environmental variables used adequately explained species distributions in the CRB and to enable comparison of SDMs among basins.

Model performance (MRB and CRB models) and transferability of the MRB models to the CRB was quantified using the area-under the receiver-operating curve (AUC), which measures the ability of the model to discriminate between species presence and absence sites (Elith et al. 2006), and is commonly used to evaluate SDM fit (e.g., Olden and Jackson 2002; Buisson et al. 2008; Strecker et al. 2011; Whitney et al. 2017) and transferability of SDMs (Randin et al. 2006; Vanreusel et al. 2007; Sundblad et al. 2009; Wenger and Olden 2012; Huang and Frimpong 2016; Iturbide et al. 2018). Area under the curve values range from 0 to 1 ; values $<0.5$ indicate predictive ability is worse than random, values from 0.5 to 0.7 indicate poor model performance (i.e., only slightly better than random), values from 0.7 to 0.9 indicate reasonable performance, and values $>$ 0.9 indicate models with very good ability to discriminate between presence and absence 
sites (Pearce and Ferrier 2000). We considered MRB SDMs with AUC $\geq 0.7$ when applied to CRB data as models with reasonable transferability.

For each species, we quantified transferability (i.e., AUC) of the MRB SDM to: 1) all stream segments in the $\mathrm{CRB}$ with fish records, and 2) a subset of stream segments in the CRB with fish records located within ecological drainage units (EDUs; groups of USGS 8-digit hydrologic units with similar fish assemblages; Sowa et al. 2007) acquired from Esselman et al. (2011b) where the species occurred to reduce the potential effects of introduction history (i.e., lack of species introductions) on model transferability. Next, we evaluated how species characteristics affected transferability to all CRB stream segments using an analysis of variance (ANOVA), which was similar to the approach used by Soininen and Luoto (2014) and Huang et al. (2016) to evaluate the effects of species characteristics on SDM transferability. Given the lack of information on which species characteristics likely affect lotic fish SDM transferability (but see Huang et al. 2016), we evaluated the effects of a variety of species characteristics on transferability: family, CRB nativity, substrate and temperature preference, reproductive guild and trophic feeding guild. We acquired reproductive guild, feeding guild, and temperature and substrate preferences from Olden et al. (2006) for most species, and the remainder from Becker (1983), Brown (1971), Pflieger (1997), and Frimpong and Angermeier (2009) for Lake Chub Couesius plumbeus and Johnny Darter Etheostoma nigrum. We conducted a global ANOVA (all species and characteristics) and characteristic-specific one-way ANOVAs limited to treatment groups with at least three species to remove potential effects of groups with small sample size on the analyses. We considered characteristic-specific 
differences significant at $\alpha=0.01$ (i.e., $0.05 / 5$ comparisons) following Bonferroni correction for multiple comparisons.

We compared MRB SDMs to CRB SDMs for each species to examine if patterns in transferability were explained by similarities and differences in SDMs. We hypothesized that transferability would be higher for MRB SDMs with high variable overlap with CRB SDMs and those that contained the most important variables in CRB SDMs. We quantified the importance of predictor variables in SDMs using delta deviance, which is the change in model fit when a predictor variable is removed (Whitney et al. 2017). Delta deviance is scaled from 0 (variable not included in model) to 100 (most important variable). We then quantified four metrics for comparison between species whose models transferred (i.e., AUC $\geq 0.7$ ) and those whose models did not transfer (AUC < 0.7): 1) variable overlap, calculated as the percent of variables from CRB SDMs that were included in MRB SDMs;2) number of MRB SDMs that contained the most-important CRB SDM variable; 3) CRB SDM importance of variables that occurred in SDMs from both basins for a species; and 4) CRB SDM importance of variables that only occurred in CRB SDMs. Consistent with Whitney et al (2017), we also evaluated if variable importance was correlated among basins for each species with Spearman correlation $(\alpha=0.05 / 25=0.002$, following Bonferroni correction for multiple comparison); variables that were omitted from SDMs received a variable importance value of zero. Finally, when the most important variable was consistent among basins, we graphically compared the effects of that variable on the probability of species occurrence to evaluate if the effect of this variable was consistent among basins. 


\section{Results}

$\underline{\text { Transferability of Species Distribution Models Across Basins }}$

For all species, SDMs created for the MRB had good predictive performance (AUC > 0.8; Table 3.2) in the MRB. These models had reasonable transferability to the CRB (AUC $\geq 0.7$ ) for 15 of 25 species (Table 3.2). The AUC was lowest for Channel Catfish Ictalurus punctatus and Mountain Sucker Catostomus platyrhynchus (AUC=0.59 and 0.61, respectively), and was highest for Lake Chub, Yellow Bullhead Ameiurus natalis, and Western Mosquitofish Gambusia affinis (AUC=0.87, 0.88 and 0.93, respectively). Limiting our analysis of transferability to stream segments within EDUs where the species occurred rarely improved transferability ( $\mathrm{n}=7$ of 25 species), and only increased AUC by $\geq 0.05$ for three species (Table 3.2).

Species distribution models had AUC values $>0.7$ for $59 \%$ of species that were non-native to the $\mathrm{CRB}, 67 \%$ of species native to the $\mathrm{CRB}, 60 \%$ of cold water species, $63 \%$ of cool water species, and $58 \%$ of warm water species (Table 3.3). Missouri River SDMs transferred to the CRB for $45 \%$ of species that prefer rubble substrate, up to $100 \%$ of species that prefer sand substrate $(\mathrm{n}=2)$. The SDMs transferred for $100 \%$ of piscivores $(n=1)$ and invertivores $(n=7)$, but only $50 \%(n=5)$ of invertivore/piscivores and $33 \%$ $(n=2)$ of omnivores (Table 3.3). Transferability was lowest for Catostomidae (33\% of species) and highest for Cottidae, Gasterosteidae, Percidae, and Poeciliidae species $(100 \% ; n=1$ each; Table 3.3).

Family, CRB nativity, temperature and substrate preferences, reproductive guild and trophic feeding guild were not significant predictors of model transferability (i.e., AUC) from the MRB to CRB ( $p=0.65$ for the global model). Additionally, one-way 
ANOVAs indicated that temperature and substrate preferences, nativity, reproductive guild, and family did not affect transferability when the analysis was limited to groups with at least three species $(p>0.6)$. Mean AUC ranged from 0.72 for native species to 0.75 for non-native species, and from 0.68 for Catostomidae to 0.93 for Poeciliidae (Table 3.3). Mean AUC ranged from 0.73 for cold water species to 0.75 for warm water species, and from 0.72 for species that prefer rubble substrate to 0.85 for those that prefer sand. Mean AUC was highest for the external bearer $(0.93 ; n=1)$ reproductive guild, followed by guarder, nest-spawner $(0.75 ; n=10)$, non-guarder, brood hiders $(0.73 ; n=5)$, and non-guarder, open substrate spawners $(0.73 ; n=9)$. There was evidence of higher transferability for invertivores (mean $=0.81)$ than omnivores (mean=0.70) and invertivore/piscivores (mean $=0.73$; Table 3.3$)$, but this relationship was not statistically significant $(p=0.02)$ following the Bonferroni correction.

\section{$\underline{\text { Species Distribution Model Comparison Among Basins }}$}

All CRB SDMs had reasonable model fit (AUC > 0.7), and all but one SDM (i.e., Golden Shiner Notemigonus crysoleucas) had an AUC > 0.8 (Table 3.2). Across species, the most important variables driving species distributions were generally consistent between the MRB and CRB. Mean annual air temperature, mean annual precipitation, and base-flow index occurred in most SDMs ( $\geq 15$ species in each basin) and had relatively high variable importance (i.e., delta deviance) across species when they occurred in SDMs (e.g., $\geq 40$; Figure 3.1; Table 3.4). Network urban land use occurred in more SDMs in the MRB $(n=18)$ than the CRB (n=4; Figure 3.1). Network crop land use, population density, and mean annual flow were more important in CRB SDMs (delta deviance $>60$ ) than in MRB SDMs (delta deviance < 40; Figure 3.1). 
Variable overlap between CRB and MRB SDMs was higher for species whose SDMs did not transfer (mean $=71.0 \%$ of CRB SDM variables included in MRB SDMs) than those whose SDMs transferred (mean=66.3\%; Figure 3.2). Missouri River Basin SDMs included all of the variables in CRB SDMs for two species whose SDMs did not transfer (i.e., Channel Catfish and Bluegill Lepomis macrochirus) and zero species whose SDMs transferred (Figure 3.2). Missouri River Basin SDMs included the most important variable (i.e., delta deviance $=100$ ) from CRB SDMs for 23 of the 25 species; this variable was omitted for one species whose SDM transferred (Brown Trout Salmo trutta; Figure 3.3), and one species whose SDM did not transfer (Mountain Sucker; Figure 3.4).

Missouri River basin SDMs that transferred well generally contained variables that were more important in CRB SDMs than those that did not transfer. Delta deviance of variables that occurred in SDMs for both basins was higher for species whose SDMs transferred (CRB average=59.8; Figure 3.2) than those that did not transfer (CRB average $=53.4$ ). Similarly, delta deviance of variables in CRB SDMs that were omitted from MRB SDMs was slightly higher for species whose models did not transfer (average $=43.0)$ than for species whose SDMs transferred (average=39.2). Delta deviance was correlated between basins for two species whose SDMs transferred from the MRB to CRB [White Sucker Catostomus commersonii $\left(r_{s}=0.78 ; \mathrm{p}<0.001\right)$ and Cutthroat Trout Oncorhynchus clarkii $\left(r_{s}=0.81 ; \mathrm{p}<0.001\right.$; Figure 3.3$\left.)\right]$, but was not correlated between basins for any species whose SDMs did not transfer (Figure 3.4). Summaries of SDM delta deviance by species characteristics and basin are presented in Appendices 3.1-3.6.

The most important variable (mean annual air temperature) was consistent among basins for eight species (Table 3.4); five whose models transferred (Yellow Bullhead, 


\section{Red Shiner Cyprinella lutrensis, Western Mosquitofish, Green Sunfish Lepomis}

cyanellus, and Cutthroat Trout), and three whose models did not transfer (Bluegill, Golden Shiner, and Brook Trout Salvelinus fontinalis). The effects of mean annual air temperature on probability of occurrence were generally consistent across basins for species whose models transferred, but were less consistent for species whose models did not transfer. The probability of Cutthroat Trout occurrence was greatest at the coldest temperatures and decreased at warmer temperatures (Figure 3.5). In both basins, the probability of occurrence generally increased with temperature for Yellow Bullhead, Red Shiner, and Western Mosquitofish (Figure 3.5). However, probability of occurrence decreased with increasing temperature over a portion of the temperature range for Yellow Bullhead and Red Shiner in the MRB, and fluctuated over a portion of the temperature range for Western Mosquitofish in the CRB. The effect of temperature on the distribution of Green Sunfish was consistent among basins (i.e., probability of occurrence increased with temperature to a maximum, then decreased with increased temperature), but probability of occurrence peaked at different temperatures among basins $\left(\mathrm{MRB}=7.9^{\circ} \mathrm{C}\right.$; $\mathrm{CRB}=17 \cdot 2^{\circ} \mathrm{C}$ ). Probability of Bluegill occurrence increased with temperature up to approximately $7.8^{\circ} \mathrm{C}$ and then decreased with increased temperature in the MRB, but temperature had little effect on probability of Bluegill occurrence in the CRB. Similarly, Golden Shiner probability of occurrence increased with temperature in the MRB, but temperature had little effect on Golden Shiner occurrence in the CRB. In the CRB, the probability of Brook Trout occurrence was highest from -1.7 to $0.7^{\circ} \mathrm{C}$, and then decreased with increasing temperature. In the MRB, the probability of Brook Trout 
occurrence increased with temperature from -1.7 to $2.7^{\circ} \mathrm{C}$, and then decreased as temperature increased.

\section{Discussion}

We found that SDMs based on landscape-level environmental factors transferred spatially across large river basins for $60 \%$ of the species evaluated. This percentage of successful transfers was higher than that observed by Huang and Frimpong (2016; 42$48 \%$ ) for 144 combinations of species-basin transfers ( 21 species, 5 river basins) across the USA and was lower than that observed by Huang et al. (2016), who found that SDMs transferred temporally within the New River Basin, USA for $81 \%$ of species using a less conservative transferability threshold $(\mathrm{AUC}=0.6)$. However, only $54 \%(\mathrm{n}=7$ of 13$)$ of the species in Huang et al. (2016) had at least one SDM that met our transferability threshold. Alternatively, $96 \%(n=24 / 25)$ of SDMs in our study met the AUC $\geq 0.6$ threshold used by Huang and Frimpong (2016) and Huang et al. (2016). These differences in percentage of successful SDM transfers between studies is likely, in part, due to the limited number of species that were consistent between studies, different transferability thresholds, and differences in modeling approaches between studies (Wenger and Olden 2012; Huang and Frimpong 2016).

Consistency of SDM transferability between studies varied by species, but our ability to compare transferability results to other studies was limited to a few species ( $n=6$ of the 25 species we evaluated). Like Wenger and Olden (2012), our Brown Trout SDMs had higher transferability than our Brook Trout SDM. Transferability of Creek Chub Semotilus atromaculatus SDMs was consistent (i.e., low: AUC < 0.7) between our study and Huang and Frimpong (2016). Transferability of our Yellow Bullhead SDM was 
higher (AUC=0.88) than SDMs in Huang and Frimpong (2016; AUC < 0.7).

Transferability was consistent between our study (spatial transferability) and Huang et al. (2016; temporal transferability) for Rainbow Trout Oncorhynchus mykiss (i.e., low, AUC $<0.7$ ), but was inconsistent between studies for Brook Trout (i.e., low in our study) and Largemouth Bass Micropterus salmoides (i.e., high in our study). Finally, Brown Trout SDM transferability was high in our study, but was only high for one of the four model types in Huang et al. (2016). These differences in transferability for individual species between studies suggest that transferability may be context-specific (e.g., vary among geographic regions or between temporal and spatial transferability studies).

Transferability of lotic fish SDMs was generally not predictable based on species characteristics. Family, nativity, and traits did not explain patterns in transferability of lotic fish SDMs when evaluated across all 25 species in our study. However, there was limited, though not statistically significant, evidence of higher transferability for invertivores than omnivores and invertivores/piscivores when we limited analysis to feeding strategies with at least three species. This finding was consistent with Dobrowski et al. (2011) and Huang and Frimpong (2016), who suggested that transferability is likely higher for species with low trait plasticity or highly specialized traits. Our results were similar to Huang et al. (2016) in that family was not an important predictor of transferability in either study, but differed in that Huang et al. (2016) identified an effect of temperature preference on transferability. The lack of strong, consistent effects of species characteristics on transferability among studies may indicate that transferability is species- and context-specific rather than predictable based on species characteristics, but the effects of traits on transferability may warrant further investigation given the potential 
differences in transferability among feeding guilds (this study) and temperature preferences (Huang et al. 2016).

Comparisons of SDMs among basins suggested that MRB SDMs were more likely to transfer when they contained variables of high importance (i.e., delta deviance) in CRB SDMs and when species-environment relationships were consistent among basins, but high variable overlap and correlated variable importance among SDMs were unnecessary for effective transferability. First, we found that MRB SDMs that transferred effectively typically included variables with higher variable importance in CRB SDMs than SDMs that did not transfer. This result was consistent with Leftwich et al. (1997), who hypothesized that different limiting factors between streams resulted in low transferability of habitat relationships for Tangerine Darters Percina aurantiaca. Second, of the eight species whose most important variable in SDMs was mean annual air temperature in both basins, we found that the effect temperature was generally more consistent between basins for the five SDMs that transferred than for the three SDMs that did not transfer. Similar to our results, Huang and Frimpong (2016) found that transferability relied on consistent species-environment relationships between regions. Contrary to our expectations, variable overlap between SDMs (i.e., percent of variables from CRB SDM that were included in MRB SDM) was generally lower for SDMs that transferred effectively than for SDMs that did not transfer. Finally, correlated variable importance among SDMs could be a useful predictor of SDM transferability but is not essential for SDM transferability because only 2 of the 15 species whose SDMs transferred between basins exhibited correlated variable importance. 
The complexity and directness of fish-environment relationships likely affect transferability of lotic fish SDMs. First, variables with direct relationships to organisms are likely more transferable than variables with indirect effects (Murray et al. 2011; Wenger and Olden 2012; Gies et al. 2015; Huang and Frimpong 2016). For example, Huang and Frimpong (2016) hypothesized that temperature, altitude, and hydrological conditions were frequently identified as important predictors due to their direct effects on survival, growth, and reproduction, but variables representing anthropogenic activities were generally less transferable. Therefore, although we found that temperature, baseflow index, precipitation, and mean annual streamflow were often important variables in SDMs in both basins, omitting anthropogenic predictor variables from SDMs may have improved transferability. Second, simple modeling approaches and species-environment relationships are likely more transferable than complex approaches and relationships (Wenger and Olden 2012; Iturbide et al. 2018). Therefore, although MARS models may have optimized model fit in the MRB, their ability to estimate complex relationships may have reduced their predictive performance in the CRB. Finally, although we identified more-complex species-temperature relationships in the MRB than CRB for Red Shiner and Yellow Bullhead, these models transferred reasonably well. This was likely due to a general positive relationship between species occurrence and temperature in both basins for both species.

Transferability of SDMs is most likely for species that exhibit high niche conservatism and have narrow niche breadth. A fundamental assumption to transferability is that a species' niche-related traits do not change over time or spatial scales relevant to the study (i.e., niche conservatism; Wiens and Graham 2005; Olden et 
al. 2010). This assumption is consistent with our finding that models generally transferred across basins when the variables driving distributions and their effects were consistent between basins. Likewise, species exhibiting wide niche breadth (i.e., ability to use a wide range of habitats or resources; Slatyer et al. 2013) are likely to have lower SDM transferability than highly specialized species because they can use different resources in different regions without fundamental changes to their ecological traits. This hypothesis was supported by our limited evidence of lower SDM transferability for generalist feeding strategies than for species with more specialized feeding strategies and by Dobrowski et al. (2011), who found lower model transferability for plant species with specialized adaptations to fire.

Our estimates of lotic fish SDM transferability were likely biased by habitat connectivity, the extent of species introductions, and the equilibrium status of the species with the environment. Our model predictions likely over-estimated realized distributions in the $\mathrm{CRB}$, and subsequently underestimated transferability, because we assumed that species had access to the entire CRB through natural movements or species introductions. However, lack of connectivity (Filipe et al. 2013) and lack of introductions would result in species absences in suitable stream reaches because the species did not have an opportunity to colonize those reaches. Furthermore, transferability would be biased if the species was not in equilibrium with its environment in either region (Elith and Leathwick 2009; Huang and Frimpong 2016). For example, our transferability estimates would be biased low if our models correctly identified reaches as unsuitable for a species where it was caught, but the species was recently introduced and did not successfully establish a self-sustaining population. 
In summary, we found that lotic fish SDMs may be transferred in space and that transferability may differ among feeding strategies but not among the other species characteristics we evaluated. To our knowledge, this was the first study to evaluate the effects of species traits on spatial SDM transferability of lotic fishes, although Huang et al. (2016) evaluated the effects of temperature preference on temporal SDM transferability. Our findings highlight the need to use caution when transferring SDMs spatially, and the need to evaluate transferability when using SDM predictions to inform non-native species management. Although it may not be possible to test SDM transferability to an area where a species has not been introduced, evaluating transferability of SDMs based on a subset of the species' range to its remaining range may provide valuable insight into the validity of using SDM predictions to address nonnative species challenges.

Our study reinforces that a tradeoff exists between SDM predictive ability where the model was developed and transferability to new areas (Elith and Leathwick 2009; Iturbide et al. 2018). Multiple studies indicated that simple modeling approaches had higher transferability than complex modeling approaches (Wenger and Olden 2012; Huang and Frimpong 2016; Iturbide et al. 2018). Similarly, we found that complex MARS SDMs had high predictive ability in the MRB, but had limited transferability to the CRB for numerous species. Therefore, researchers may maximize transferability by using simple modeling approaches. Second, SDMs developed with predictor variables that have direct ecological links to species ecology likely have higher transferability than SDMs that include variables with complex or indirect ecological effects (Murray et al. 2011; Wenger and Olden 2012; Gies et al. 2015; Huang and Frimpong 2016), but 
omitting potentially ecologically important variables from SDMs may limit SDM predictive ability if these variables are important drivers of species distributions where the models were developed. In conclusion, using simple modeling approaches and variables with direct ecological linkages may increase transferability, but may also decrease performance where SDMs were developed.

\section{References}

Annis, G. M., S. P. Sowa, D. D. Diamond, A. Garringer, P. Hanberry, and M. E. Morey. 2010. A GAP analysis for riverine ecosystems of the Missouri River basin. Final report submitted to the USGS National Gap Analysis Program. 1,351 pp.

Becker, G. C. 1983. Fishes of Wisconsin. University of Wisconsin Press, Madison, WI.

Blinn, D. W. and N. L. Poff. 2005. Colorado River basin. Pages 483-538 in A. Benke and C.E. Cushing, editors. Rivers of North America. Elsevier, Oxford.

Brown, C. J. D. 1971. The fishes of Montana. Big Sky Books, Montana State University, Bozeman, MT.

Buisson, L., L. Blanc, and G. Grenouillet. 2008. Modelling stream fish distribution in a river network: The relative effects of temperature versus physical factors. Ecology of Freshwater Fish 17:244-257.

Carlson, C. A, and R. T. Muth 1989. The Colorado River: Lifeline of the American Southwest. Canadian Special Publication of Fisheries and Aquatic Sciences 106: $220-239$.

Cress, J., D. Soller, R. Sayer, P. Comer, and H. Warner. 2010. Terrestrial ecosystems surficial lithology of the conterminous United States: U.S. Geological Survey 
Scientific Investigations Map 3126. Available at http://rmgsc.cr.usgs. gov/outgoing/ecosystems/USdata/lithology_1km.zip. Accessed 11/13/2013.

Dobrowski, S. Z., J. H. Thorne, J. A. Greenberg, H. D. Safford, A. R. Mynsberge, S. M. Crimmins, and A. K. Swanson. 2011. Modeling plant distributions over 75 years of measured climate change in California, USA: Relating temporal transferability to species traits. Ecological Monographs 81:241-257.

Elith, J., C. H. Graham, R. P. Anderson, M., Dudík, S. Ferrier, A. Guisan, R. J. Hijmans, F. Huettmann, J. R. Leathwick, A. Lehmann, J. Li, L. G. Lohmann, B. A. Loiselle, G. Manion, C. Moritz, M. Nakamura, Y. Nakazawa, J. M. Overton, A. T. Peterson, S. J. Phillips, K. Richardson, R. Scachetti-Pereira, R. E. Schapire, J. Soberón, S. Williams, M. S. Wisz, M. and N. E. Zimmermann. 2006. Novel methods improve prediction of species' distributions from occurrence data. Ecography 29:129-151.

Elith, J., and J. R. Leathwick. 2009. Species distribution models: Ecological explanation and predictions across space and time. The Annual Review of Ecology, Evolution, and Systematics 40:677-697.

ESRI (Environmental System Research Institute). 2009. ArcGIS version 9.3. Environmental System Research Institute, Redlands, CA. Esselman, P. C., D. M. Infante, L. Wang, W.W. Taylor, W. M. Daniel, R. Tingley, J. Fenner, A. Cooper, D. Wieferich, D. Thornbrugh, and J. Ross. 2011a. National Fish Habitat Action Plan (NFHAP) 2010 HCI scores and human disturbance data for conterminous United States linked to NHDPLUSV1. United States Geological 
Survey- National Fish Habitat Partnership, Reston, VA. Available at http://dx.doi.org/doi:10.5066/F7B56GN1. Accessed 8/19/2013.

Esselman, P. C., D. M. Infante, L. Wang, W.W. Taylor, W. M. Daniel, R. Tingley, J. Fenner, A. Cooper, D. Wieferich, D. Thornbrugh, and J. Ross. 2011b. National Fish Habitat Action Plan (NFHAP) 2010 HCI scores for conterminous United States -by EDU. United States Geological Survey- National Fish Habitat Partnership, Reston, VA. Available at http://dx.doi.org/doi:10.5066/F70P0WXC. Accessed 12/11/2017.

Filipe, A. F., D. Markovic, F. Pletterbauer, C. Tisseuil, A. De Wever, S. Schmutz, N. Bonada, and J. Freyhof. 2013. Forecasting fish distribution along stream networks: Brown trout (Salmo trutta) in Europe. Diversity and Distributions 19:1059-1071.

Frimpong, E. A., and P. L. Angermeier. 2009. Fish traits: A database of ecological and life-history traits of freshwater fishes of the United States. Fisheries 34: 487-495.

Galat, D. L., C. R. Berry Jr., E. J. Peters, and R. G. White. 2005. Missouri River basin. Pages 427-480 in A. C. Benke and C. E. Cushing, editors. Rivers of North America. Elsevier, Oxford.

Gies M., M. Sondermann, D. Hering, and C. K. Feld. 2015. Are species distribution models based on broad-scale environmental variables transferable across adjacent watersheds? A case study with eleven macroinvertebrate species. Fundamental and Applied Limnology 186:63-97.

Guisan, A., and W. Thuiller. 2005. Predicting species distribution: Offering more than simple habitat models. Ecology Letters 8:993-1009. 
Huang, J., and E. A. Frimpong. 2016. Limited transferability of stream-fish distribution models among river catchments: Reasons and implications. Freshwater Biology 61:729-744.

Huang, J., E. A. Frimpong, and D. J. Orth. 2016. Temporal transferability of stream fish distribution models: Can uncalibrated SDMs predict distribution shifts over time? Diversity and Distributions 22:651-662.

Iturbide, M., J. Bedia, and J. M. Gutiérrez. 2018. Background sampling and transferability of species distribution model ensembles under climate change. Global and Planetary Change 166:19-29.

Leathwick, J. R., J. Elith, and T. Hastie. 2006. Comparative performance of generalized additive models and multivariate adaptive regression splines for statistical modelling of species distributions. Ecological Modelling 199:188-196.

Leftwich, K. N., P. L. Angermeier, and C. A. Dolloff. 1997. Factors influencing behavior and transferability of habitat models for a benthic stream fish. Transactions of the American Fisheries Society 126:725-734.

Malmqvist, B., and S. Rundle. 2002. Threats to running water ecosystems of the world. Environmental Conservation 29:134-153.

McKay, L., T. Bondelid, T. Dewald, J. Johnston, R. Moore, and A Rea. 2012. NHDPlus version 2: user guide. Available at ftp://ftp.horizon-systems.com/NHDplus/ NHDPlusV21/Documentation/NHDPlusV2_User_Guide.pdf. Accessed $1 / 28 / 2019$

Milborrow, S. 2017. Package 'earth'. Available at https://cran.rproject.org/web/packages/ earth/earth.pdf. Accessed 12/2/2017. 
Miller, R. R., J. D., Williams, and J. E. Williams. 1989. Extinctions of North American fishes during the past century. Fisheries 14:22-38.

Mueller, G. A., P. C. Marsh, and W. L. Minckley. 2005. A legacy of change: The lower Colorado River, Arizona-California-Nevada, USA and Sonora-Baja California Norte, Mexico. Pages 139-156 in J. Rinne, R. M. Hughes, and B. Calamusso, editors. Historical changes in large river fish assemblages of the Americas. American Fisheries Society Symposium 45, Bethesda, MD.

Murray J. V., S. Low Choy, C. A. McAlpine, H. P. Possingham, and A. W. Goldizen. 2011. Evaluating model transferability for a threatened species to adjacent areas: Implications for rock-wallaby conservation. Austral Ecology 36:76-89.

Olden, J. D., and D. A. Jackson. 2002. A comparison of statistical approaches for modelling fish species distributions. Freshwater Biology 47:1976-1955.

Olden, J. D., M. K. Kennard, F. Leprieur, P. A. Tedesco, K. O. Winemiller, and E. García-Berthou. 2010. Conservation biogeography of freshwater fishes: past progress and future directions. Diversity and Distributions 16: 496-513.

Olden, J. D., N. L. Poff, and K. B. Bestgen. 2006. Life-history strategies predict fish invasions and extirpations in the Colorado River basin. Ecological Monographs $73: 25-40$.

Pearce, J., and S. Ferrier. 2000. Evaluating the predictive performance of habitat models developed using logistic regression. Ecological Modelling 133:225-245.

Peterson, A. T. 2003. Predicting the geography of species invasions via ecological niche modeling. The Quarterly Review of Biology 78:419-433. 
Pflieger, W. L. 1997. Fishes of Missouri, revised edition. Missouri Department of Conservation, Jefferson City.

R Core Team. 2017. R: A language and environment for statistical computing. $R$ Foundation for Statistical Computing, Vienna, Austria. Available at https://www.R-project.org/.

Randin, C. F., T. Dirnböck, S. Dullinger, N. E. Zimmerman, M. Zappa, and A. Guisan. 2006. Are niche-based distribution models transferable in space?. Journal of Biogeography 33:1689-1703.

Slayter, R. A., M. Hirst, and J. P. Sexton. 2013. Niche breadth predicts geographical range size: A general ecological pattern. Ecology Letters 16:1104-1114.

Soininen, J., and M. Luoto. 2014. Predictability in species distributions: A global analysis across organisms and ecosystems. Global Ecology and Biogeography 23:12641274

Sowa, S., G. Annis, M. Morey, and D. Diamond. 2007. A gap analysis and comprehensive conservation strategy for riverine ecosystems of Missouri. Ecological Monographs 77:301-334.

Strecker, A., S., J. D. Olden, J. B. Whittier, and C. P. Paukert. 2011. Defining conservation priorities for freshwater fishes according to taxonomic, functional, and phylogenetic diversity. Ecological Applications 21:3002-3013.

Sundblad, G., M. Härmä, A. Lappalainen, L. Urho, and U. Bergström. 2009. Transferability of predictive fish distribution models in two coastal systems. Estuarine, Coastal and Shelf Science 83:90-96. 
USEPA (U.S. Environmental Protection Agency). 2005. National hydrography dataset plus - NHDPlus- Strahler order. Available at http://www.horizonsystems.com/nhdplus/strahlerlist.php. Accessed 4/1/2017.

USEPA (U.S. Environmental Protection Agency). 2015. The StreamCat dataset: accumulated attributes for NHDPlusV2 (Version 2.1) catchments for the conterminous United States: PRISM normals data. Available at $\mathrm{ftp} / / /$ newftp.epa.gov/EPADataCommons/ORD/NHDPlusLandscapeAttributes/Stre amCat/HydroRegions/. Accessed 11/16/2017.

USEPA (U.S. Environmental Protection Agency) and USGS (U.S. Geological Survey). 2005. National hydrography dataset plus - NHDPlus. Available at http://www.horizon-systems.com/NHDPlus/NHDPlusV1_data.php. Accessed 6/28/2013.

Valdez, R. A., and R. M. Muth. 2005. Ecology and conservation of native fishes in the upper Colorado River basin. Pages 157-205 in J. Rinne, R.M. Hughes, and B. Calamusso, editors. Historical changes in large river fish assemblages of the Americas. American Fisheries Society Symposium 45, Bethesda, MD.

Vanreusel, W., D. Maes, and H. Van Dyck. 2007. Transferability of species distribution models: A functional habitat approach for two regionally threatened butterflies. Conservation Biology 21:201-212.

Wenger, S. J., and J. D. Olden. 2012. Assessing transferability of ecological models: An underappreciated aspect of statistical validation. Methods in Ecology and Evolution 3:260-267. 
Whitney, J. E., J. B. Whittier, and C. P. Paukert. 2017. Environmental niche models for riverine desert fishes and their similarity according to phylogeny and functionality. Ecosphere 8:1-21.

Whittier, J. B., C. P. Paukert, J. D. Olden, K. L. Pitts, and A. L. Strecker. 2011. Lower Colorado River basin aquatic gap analysis project: Final report. U.S. Geological Survey, Gap Analysis Program, Reston, VA.

Whittier, J. B., and N. Sievert. 2014. Conservation assessment for native fish in the Upper Colorado River Basin. Final report to the Western Native Trout Initiative and National Fish Habitat Partnership, Lakewood, CO.

Wiens, J. J., and C. H. Graham. 2005. Niche conservatism: Integrating evolution, ecology, and conservation biology. Annual Review of Ecology, Evolution, and Systematics 36:519-539.

Wieczorek, M. E. and A. E. LaMotte. 2010a. Attributes for NHDPlus catchments (Version 1.1) for the conterminous United States: Base-flow index. Available at https://water.usgs.gov/lookup/getspatial?nhd_bfi. Accessed 6/28/2013.

Wieczorek, M. E. and A. E. LaMotte. 2010b. Attributes for NHDPlus catchments (Version 1.1) for the conterminous United States: Basin characteristics, 2002. Available at https://water.usgs.gov/lookup/getspatial?nhd_bchar. Accessed $6 / 28 / 2013$

Wittenberg, R., and M. J. W. Cock, editors. 2001. Invasive alien species: A toolkit of best prevention and management practices. CAB International, Wallingford, Oxon, United Kingdom. 
Yates, K. L, P. J. Bouchet, M. J. Caley, K. Mengersen, C. F. Randin, S. Parnell, A. H. Fielding, A. J. Bamford, S. Ben, A. M. Barbosa, C. F. Dormann, J. Elith, C. B. Embling, G. N. Erving, R. Fisher, S., Gould, R. F. Graf, E. J. Gregr, P. N. Halpin, R. K. Heikkinen, S. Heinänen, A. R. Jones, P. K. Krishnakumar, V. Lauria, H. Lozano-Montes, L. Mannocci, C. Mellin, M. B. Mesgaran, E. Moreno-Amat, S. Mormede, E. Novaczek, S. Oppel, G. O. Crespo, A. T. Peterson, G. Rapacciuolo, J. J. Roberts, R. E. Ross, K. L. Scales, D. Schoeman, P. Snelgrove, G. Sundblad, W. Thuiller, L. G. Torres, H. Verbruggen, L. Wang, S. Wenger, M. J. Whittingham, Y. Zharikov, D. Zurell, and A. M. M. Sequeira. 2018. Outstanding challenges in the transferability of ecological models. Trends in Ecology and Evolution 33:790-802. 


\section{Tables}

Table 3.1. Landscape-scale environmental variables used as predictor variables in multivariate adaptive regression spline species distribution models in the Missouri River (MRB) and Colorado River (CRB) basins. Variables without a code were excluded from models because they were highly correlated with other variables.

\begin{tabular}{|c|c|c|c|c|c|c|c|c|c|}
\hline \multirow[b]{2}{*}{ Variable } & \multirow[b]{2}{*}{ Scale } & \multirow[b]{2}{*}{ Source } & \multirow{2}{*}{$\begin{array}{l}\text { Variable } \\
\text { Code }\end{array}$} & \multicolumn{3}{|c|}{$\mathrm{CRB}$} & \multicolumn{3}{|c|}{ MRB } \\
\hline & & & & Min & $\operatorname{Max}$ & Median & Min & Max & Median \\
\hline Strahler stream order & Segment & USEPA 2005 & $\mathrm{SO}$ & 1 & 4 & 2 & 1 & 4 & 3 \\
\hline $\begin{array}{l}\text { Average base-flow index for each } \\
\text { catchment }(\%)\end{array}$ & Segment & $\begin{array}{l}\text { Wieczorek and LaMotte } \\
2010 \mathrm{a}\end{array}$ & BFI & 2.0 & 78.9 & 59.3 & 8.0 & 85.0 & 45.0 \\
\hline $\begin{array}{l}\text { Mean annual flow (cfs) at bottom of } \\
\text { flowline as computed by Unit Runoff } \\
\text { Method }\end{array}$ & Segment & USEPA and USGS 2005 & Flow & 0.0 & 655.3 & 4.0 & 0.0 & 409.3 & 3.2 \\
\hline $\begin{array}{l}\text { Mean annual velocity (fps) at bottom } \\
\text { of flowline as computed by Unit } \\
\text { Runoff Method }\end{array}$ & Segment & USEPA and USGS 2005 & Velo & 0.1 & 2.9 & 1.2 & 0.4 & 2.1 & 1.0 \\
\hline Mean slope $(\%)$ & $\begin{array}{l}\text { Local } \\
\text { catchment }\end{array}$ & $\begin{array}{l}\text { Wieczorek and LaMotte } \\
2010 \mathrm{~b}\end{array}$ & Slope & 0.4 & 118.8 & 23.6 & 0.0 & 69.0 & 7.1 \\
\hline Mean elevation (m) & $\begin{array}{l}\text { Local } \\
\text { catchment }\end{array}$ & $\begin{array}{l}\text { Wieczorek and LaMotte } \\
2010 \mathrm{~b}\end{array}$ & & 140.7 & 3821.6 & 2335.6 & 148.3 & 2957.0 & 794.6 \\
\hline Number of dams in catchment & $\begin{array}{l}\text { Local } \\
\text { catchment }\end{array}$ & Esselman et al. 2011a & L_Dam & 0.0 & 3.0 & 0.0 & 0.0 & 17.0 & 0.0 \\
\hline $\begin{array}{l}\text { Percent of catchment defined as } \\
\text { cultivated crops }\end{array}$ & $\begin{array}{l}\text { Local } \\
\text { catchment }\end{array}$ & Esselman et al. 2011a & & 0.0 & 78.5 & 0.0 & 0.0 & 100.0 & 1.2 \\
\hline Percent of catchment defined as urban & $\begin{array}{l}\text { Local } \\
\text { catchment }\end{array}$ & Esselman et al. 2011a & & 0.0 & 99.9 & 0.0 & 0.0 & 100.0 & 2.1 \\
\hline $\begin{array}{l}\text { Mean population density within } \\
\text { catchment }\left(\# / \mathrm{km}^{2}\right)\end{array}$ & $\begin{array}{l}\text { Local } \\
\text { catchment }\end{array}$ & Esselman et al. 2011a & & 0.0 & 1455.2 & 0.5 & 0.0 & 820.4 & 0.8 \\
\hline
\end{tabular}




\begin{tabular}{|c|c|c|c|c|c|c|c|c|c|}
\hline \multirow[b]{2}{*}{ Variable } & \multirow[b]{2}{*}{ Scale } & \multirow[b]{2}{*}{ Source } & \multirow{2}{*}{$\begin{array}{l}\text { Variable } \\
\text { Code }\end{array}$} & \multicolumn{3}{|c|}{$\mathrm{CRB}$} & \multicolumn{3}{|c|}{ MRB } \\
\hline & & & & Min & Max & Median & Min & Max & Median \\
\hline $\begin{array}{l}\text { The 30-year (1981-2010) average } \\
\text { annual normal precipitation ( } \mathrm{mm}) \\
\text { within the total upstream watershed }\end{array}$ & $\begin{array}{l}\text { Network } \\
\text { watershed }\end{array}$ & USEPA 2015 & Precip & 123.6 & 1556.3 & 682.0 & 156.5 & 1688.3 & 756.5 \\
\hline $\begin{array}{l}\text { The } 30 \text {-year }(1981-2010) \text { average } \\
\text { annual normal minimum air } \\
\text { temperature }\left({ }^{\circ} \mathrm{C}\right) \text { within the total } \\
\text { upstream watershed }\end{array}$ & $\begin{array}{l}\text { Network } \\
\text { watershed }\end{array}$ & USEPA 2015 & & -8.0 & 15.8 & -2.6 & -7.2 & 7.8 & 0.2 \\
\hline $\begin{array}{l}\text { The } 30 \text {-year }(1981-2010) \text { average } \\
\text { annual normal maximum air } \\
\text { temperature }\left({ }^{\circ} \mathrm{C}\right) \text { within the total } \\
\text { upstream watershed }\end{array}$ & $\begin{array}{l}\text { Network } \\
\text { watershed }\end{array}$ & USEPA 2015 & & 4.7 & 30.7 & 11.5 & 3.8 & 19.8 & 14.6 \\
\hline $\begin{array}{l}\text { The } 30 \text {-year }(1981-2010) \text { average } \\
\text { annual normal mean air temperature } \\
\left({ }^{\circ} \mathrm{C}\right) \text { within the total upstream } \\
\text { watershed }\end{array}$ & $\begin{array}{l}\text { Network } \\
\text { watershed }\end{array}$ & USEPA 2015 & Temp & -1.5 & 23.2 & 4.5 & -1.7 & 13.8 & 7.5 \\
\hline $\begin{array}{l}\text { Percent of watershed defined as non- } \\
\text { carbonate surficial lithology }\end{array}$ & $\begin{array}{l}\text { Network } \\
\text { watershed }\end{array}$ & Cress et al. 2010 & Lit3 & 0.0 & 100.0 & 41.1 & 0.0 & 100.0 & 30.5 \\
\hline $\begin{array}{l}\text { Percent of watershed defined as silicic } \\
\text { surficial lithology }\end{array}$ & $\begin{array}{l}\text { Network } \\
\text { watershed }\end{array}$ & Cress et al. 2010 & Lit5 & 0.0 & 100.0 & 15.6 & 0.0 & 100.0 & 0.0 \\
\hline $\begin{array}{l}\text { Percent of watershed defined as } \\
\text { alluvium and fine-textured coastal zone } \\
\text { sediment surficial lithology }\end{array}$ & $\begin{array}{l}\text { Network } \\
\text { watershed }\end{array}$ & Cress et al. 2010 & Lit19 & 0.0 & 100.0 & 0.0 & 0.0 & 100.0 & 0.0 \\
\hline Number of dams in watershed & $\begin{array}{l}\text { Network } \\
\text { watershed }\end{array}$ & Esselman et al. 2011a & N_Dam & 0.0 & 86.0 & 0.0 & 0.0 & 1285.0 & 0.0 \\
\hline $\begin{array}{l}\text { Percent of watershed defined as } \\
\text { cultivated crops }\end{array}$ & $\begin{array}{l}\text { Network } \\
\text { watershed }\end{array}$ & Esselman et al. 2011a & N_Crop & 0.0 & 75.8 & 0.0 & 0.0 & 97.3 & 2.7 \\
\hline Percent of watershed defined as urban & $\begin{array}{l}\text { Network } \\
\text { watershed }\end{array}$ & Esselman et al. 2011a & N_Urban & 0.0 & 99.9 & 0.0 & 0.0 & 92.6 & 1.8 \\
\hline $\begin{array}{l}\text { Mean population density within } \\
\text { watershed }\left(\# / \mathrm{km}^{2}\right)\end{array}$ & $\begin{array}{l}\text { Network } \\
\text { watershed }\end{array}$ & Esselman et al. 2011a & N_Pop & 0.0 & 1325.6 & 0.5 & 0.0 & 893.5 & 0.6 \\
\hline
\end{tabular}


Table 3.2. Species characteristics, performance of multivariate adaptive regression spline species distribution models developed for the Missouri (MRB) and Colorado River (CRB) basins quantified as the area under the receiver-operating curve (AUC), model transferability from the $\mathrm{MRB}$ to the entire $\mathrm{CRB}(\mathrm{MRB} \rightarrow \mathrm{CRB})$ and ecological drainage units (EDU) that the species occurred $[\mathrm{MRB} \rightarrow \mathrm{CRB}(\mathrm{EDU})]$, and the difference in AUC between transferability MRB $\rightarrow$ CRB (EDU) and MRB $\rightarrow \mathrm{CRB}[\Delta(\mathrm{EDU})] . \mathrm{I}=\mathrm{non}-$ native; $N=$ native for nativity. G_NS= guarder, nest spawner; NG_OS= non-guarder, open substratum spawner, $B \_E=$ external bearer, NG_BH= non-guarder, brood hider for reproductive guild.

\begin{tabular}{|c|c|c|c|c|c|c|c|c|c|c|c|c|c|c|}
\hline \multirow[b]{2}{*}{$\begin{array}{l}\text { Species } \\
\text { Code }\end{array}$} & \multirow[b]{2}{*}{$\begin{array}{l}\text { Common } \\
\text { Name }\end{array}$} & \multirow[b]{2}{*}{$\begin{array}{l}\text { Scientific } \\
\text { Name }\end{array}$} & \multirow[b]{2}{*}{ Family } & \multicolumn{2}{|c|}{ Nativity } & \multirow[b]{2}{*}{$\begin{array}{l}\text { Temperature } \\
\text { Preference }\end{array}$} & \multirow[b]{2}{*}{$\begin{array}{l}\text { Substrate } \\
\text { Preference }\end{array}$} & \multirow[b]{2}{*}{$\begin{array}{l}\text { Reproductive } \\
\text { Guild }\end{array}$} & \multirow[b]{2}{*}{$\begin{array}{l}\text { Trophic } \\
\text { Guild }\end{array}$} & \multicolumn{5}{|c|}{ AUC } \\
\hline & & & & CRB & MRB & & & & & MRB & CRB & $\begin{array}{c}\mathrm{MRB} \\
\underset{\mathrm{CRB}}{\rightarrow}\end{array}$ & $\begin{array}{c}\mathrm{MRB} \rightarrow \\
\mathrm{CRB} \\
(\mathrm{EDU})\end{array}$ & $\begin{array}{c}\Delta \\
(\mathrm{EDU})\end{array}$ \\
\hline AMME & Black Bullhead & $\begin{array}{l}\text { Ameiurus } \\
\text { melas }\end{array}$ & Ictaluridae & I & $\mathrm{N}$ & Warm & Silt/mud & G_NS & $\begin{array}{l}\text { Invertivore/ } \\
\text { piscivore }\end{array}$ & 0.841 & 0.921 & 0.755 & 0.734 & -0.021 \\
\hline AMNA & $\begin{array}{l}\text { Yellow } \\
\text { Bullhead }\end{array}$ & $\begin{array}{l}\text { Ameiurus } \\
\text { natalis }\end{array}$ & Ictaluridae & I & $\mathrm{N}$ & Warm & Rubble & G_NS & $\begin{array}{l}\text { Invertivore/ } \\
\text { piscivore }\end{array}$ & 0.906 & 0.960 & 0.883 & 0.673 & -0.210 \\
\hline CACA & $\begin{array}{l}\text { Longnose } \\
\text { Sucker }\end{array}$ & $\begin{array}{l}\text { Catostomus } \\
\text { catostomus }\end{array}$ & Catostomidae & I & $\mathrm{N}$ & Cool & Rubble & NG_OS & Omnivore & 0.935 & 0.938 & 0.697 & 0.651 & -0.046 \\
\hline $\mathrm{CACO}$ & White Sucker & $\begin{array}{l}\text { Catostomus } \\
\text { commersonii }\end{array}$ & Catostomidae & I & $\mathrm{N}$ & Cool & General & NG_OS & Omnivore & 0.824 & 0.898 & 0.746 & 0.756 & 0.010 \\
\hline CAPT & $\begin{array}{l}\text { Mountain } \\
\text { Sucker }\end{array}$ & $\begin{array}{l}\text { Catostomus } \\
\text { platyrhynchus }\end{array}$ & Catostomidae & $\mathrm{N}$ & $\mathrm{N}$ & Cool & Rubble & NG_OS & $\begin{array}{l}\text { Herbivore/ } \\
\text { detritivore }\end{array}$ & 0.965 & 0.903 & 0.606 & 0.668 & 0.062 \\
\hline COBA & $\begin{array}{l}\text { Mottled } \\
\text { Sculpin }\end{array}$ & Cottus bairdii & Cottidae & $\mathrm{N}$ & $\mathrm{N}$ & Cold & Rubble & NG_BH & Invertivore & 0.912 & 0.884 & 0.742 & 0.611 & -0.131 \\
\hline COPL & Lake Chub & $\begin{array}{l}\text { Couesius } \\
\text { plumbeus }\end{array}$ & Cyprinidae & I & $\mathrm{N}$ & Cool & Sand & NG_OS & Invertivore & 0.952 & 0.990 & 0.865 & 0.762 & -0.103 \\
\hline CUIN & $\begin{array}{l}\text { Brook } \\
\text { Stickleback }\end{array}$ & $\begin{array}{l}\text { Culaea } \\
\text { inconstans }\end{array}$ & Gasterosteidae & I & $\mathrm{N}$ & Cool & Silt/ mud & G_NS & Invertivore & 0.966 & 0.971 & 0.747 & 0.694 & -0.053 \\
\hline CYCA & Common Carp & $\begin{array}{l}\text { Cyprinus } \\
\text { carpio }\end{array}$ & Cyprinidae & I & I & Warm & Silt/ mud & NG_OS & Omnivore & 0.851 & 0.836 & 0.713 & 0.732 & 0.019 \\
\hline CYLU & Red Shiner & $\begin{array}{l}\text { Cyprinella } \\
\text { lutrensis }\end{array}$ & Cyprinidae & I & $\mathrm{N}$ & Warm & General & NG_OS & Invertivore & 0.958 & 0.905 & 0.833 & 0.824 & -0.009 \\
\hline ETNI & Johnny Darter & $\begin{array}{l}\text { Etheostoma } \\
\text { nigrum }\end{array}$ & Percidae & I & $\mathrm{N}$ & Cool & Sand & G_NS & Invertivore & 0.932 & 1.000 & 0.842 & 0.885 & 0.043 \\
\hline GAAF & $\begin{array}{l}\text { Western } \\
\text { Mosquitofish }\end{array}$ & $\begin{array}{l}\text { Gambusia } \\
\text { affinis }\end{array}$ & Poeciliidae & I & I & Warm & Silt/ mud & B_E & Invertivore & 0.927 & 0.946 & 0.926 & 0.896 & -0.030 \\
\hline ICPU & $\begin{array}{l}\text { Channel } \\
\text { Catfish }\end{array}$ & $\begin{array}{l}\text { Ictalurus } \\
\text { punctatus }\end{array}$ & Ictaluridae & I & $\mathrm{N}$ & Warm & Silt/ mud & G_NS & $\begin{array}{l}\text { Invertivore/ } \\
\text { piscivore }\end{array}$ & 0.914 & 0.904 & 0.590 & 0.550 & -0.040 \\
\hline
\end{tabular}




\begin{tabular}{|c|c|c|c|c|c|c|c|c|c|c|c|c|c|c|}
\hline \multirow[b]{2}{*}{$\begin{array}{l}\text { Species } \\
\text { Code }\end{array}$} & \multirow[b]{2}{*}{$\begin{array}{l}\text { Common } \\
\text { Name }\end{array}$} & \multirow[b]{2}{*}{$\begin{array}{l}\text { Scientific } \\
\text { Name }\end{array}$} & \multirow[b]{2}{*}{ Family } & \multicolumn{2}{|c|}{ Nativity } & \multirow[b]{2}{*}{$\begin{array}{l}\text { Temperature } \\
\text { Preference }\end{array}$} & \multirow[b]{2}{*}{$\begin{array}{c}\text { Substrate } \\
\text { Preference }\end{array}$} & \multirow[b]{2}{*}{$\begin{array}{l}\text { Reproductive } \\
\text { Guild }\end{array}$} & \multirow[b]{2}{*}{$\begin{array}{c}\text { Trophic } \\
\text { Guild }\end{array}$} & \multicolumn{5}{|c|}{ AUC } \\
\hline & & & & CRB & MRB & & & & & MRB & CRB & $\begin{array}{c}\mathrm{MRB} \\
\overrightarrow{\mathrm{CRB}} \\
\end{array}$ & $\begin{array}{c}\mathrm{MRB} \rightarrow \\
\mathrm{CRB} \\
(\mathrm{EDU})\end{array}$ & $\begin{array}{c}\Delta \\
(\mathrm{EDU}) \\
\end{array}$ \\
\hline LECY & Green Sunfish & $\begin{array}{l}\text { Lepomis } \\
\text { cyanellus }\end{array}$ & Centrarchidae & I & $\mathrm{N}$ & Warm & Silt/mud & G_NS & $\begin{array}{l}\text { Invertivore/ } \\
\text { piscivore }\end{array}$ & 0.926 & 0.910 & 0.824 & 0.772 & -0.052 \\
\hline LEMA & Bluegill & $\begin{array}{l}\text { Lepomis } \\
\text { macrochirus }\end{array}$ & Centrarchidae & I & $\mathrm{N}$ & Warm & General & G_NS & $\begin{array}{l}\text { Invertivore/ } \\
\text { piscivore }\end{array}$ & 0.949 & 0.880 & 0.681 & 0.656 & -0.025 \\
\hline MISA & $\begin{array}{l}\text { Largemouth } \\
\text { Bass }\end{array}$ & $\begin{array}{l}\text { Micropterus } \\
\text { salmoides }\end{array}$ & Centrarchidae & I & $\mathrm{N}$ & Warm & Silt/ mud & G_NS & Piscivore & 0.926 & 0.961 & 0.777 & 0.749 & -0.028 \\
\hline NOCR & Golden Shiner & $\begin{array}{l}\text { Notemigonus } \\
\text { crysoleucas }\end{array}$ & Cyprinidae & I & $\mathrm{N}$ & Warm & Silt/ mud & NG_OS & Omnivore & 0.889 & 0.729 & 0.666 & 0.594 & -0.072 \\
\hline NOST & Sand Shiner & $\begin{array}{l}\text { Notropis } \\
\text { stramineus }\end{array}$ & Cyprinidae & I & $\mathrm{N}$ & Warm & Rubble & NG_OS & Omnivore & 0.914 & 0.942 & 0.680 & 0.818 & 0.138 \\
\hline ONCL & Cutthroat Trout & $\begin{array}{l}\text { Oncorhynchus } \\
\text { clarkii }\end{array}$ & Salmonidae & $\mathrm{N}$ & $\mathrm{N}$ & Cold & Rubble & NG_BH & $\begin{array}{l}\text { Invertivore/ } \\
\text { piscivore }\end{array}$ & 0.954 & 0.878 & 0.811 & 0.765 & -0.046 \\
\hline ONMY & Rainbow Trout & $\begin{array}{l}\text { Oncorhynchus } \\
\text { mykiss }\end{array}$ & Salmonidae & I & I & Cold & Rubble & NG_BH & $\begin{array}{l}\text { Invertivore/ } \\
\text { piscivore }\end{array}$ & 0.893 & 0.816 & 0.697 & 0.695 & 0.002 \\
\hline PIPR & $\begin{array}{l}\text { Fathead } \\
\text { Minnow }\end{array}$ & $\begin{array}{l}\text { Pimephales } \\
\text { promelas }\end{array}$ & Cyprinidae & I & $\mathrm{N}$ & Warm & Silt/mud & G_NS & Omnivore & 0.907 & 0.845 & 0.689 & 0.689 & 0.000 \\
\hline RHCA & Longnose Dace & $\begin{array}{l}\text { Rhinichthys } \\
\text { cataractae }\end{array}$ & Cyprinidae & I & $\mathrm{N}$ & Cool & Rubble & NG_OS & Invertivore & 0.943 & 0.905 & 0.741 & 0.704 & -0.037 \\
\hline SAFO & Brook Trout & $\begin{array}{l}\text { Salvelinus } \\
\text { fontinalis }\end{array}$ & Salmonidae & I & I & Cold & Rubble & NG_BH & $\begin{array}{l}\text { Invertivore/ } \\
\text { piscivore }\end{array}$ & 0.946 & 0.872 & 0.690 & 0.684 & -0.006 \\
\hline SATR & Brown Trout & Salmo trutta & Salmonidae & I & I & Cold & Rubble & NG_BH & $\begin{array}{l}\text { Invertivore/ } \\
\text { piscivore }\end{array}$ & 0.909 & 0.861 & 0.718 & 0.712 & -0.006 \\
\hline SEAT & Creek Chub & $\begin{array}{l}\text { Semotilus } \\
\text { atromaculatus }\end{array}$ & Cyprinidae & I & $\mathrm{N}$ & Cool & Rubble & G_NS & $\begin{array}{l}\text { Invertivore/ } \\
\text { piscivore }\end{array}$ & 0.929 & 0.925 & 0.667 & 0.757 & 0.090 \\
\hline
\end{tabular}


Table 3.3. Total number of species, number and percent of species whose multivariate adaptive regression spline species distribution models transferred from the Missouri River Basin to the Colorado River Basin, and average and standard deviation (SD) of area under the receiver-operating curve (AUC) values by species characteristic.

\begin{tabular}{|c|c|c|c|c|c|c|}
\hline \multirow[b]{2}{*}{ Category } & \multirow[b]{2}{*}{ Group } & \multicolumn{3}{|c|}{ Species } & \multicolumn{2}{|c|}{ AUC } \\
\hline & & Total & $\begin{array}{c}\text { Transferred } \\
\text { (n) }\end{array}$ & $\begin{array}{c}\text { Transferred } \\
(\%)\end{array}$ & Average & SD \\
\hline \multirow[t]{2}{*}{ Native } & Non-native & 22 & 13 & 59 & 0.75 & 0.08 \\
\hline & Native & 3 & 2 & 67 & 0.72 & 0.10 \\
\hline \multirow[t]{3}{*}{ Temperature } & Cold & 5 & 3 & 60 & 0.73 & 0.05 \\
\hline & Cool & 8 & 5 & 63 & 0.74 & 0.09 \\
\hline & Warm & 12 & 7 & 58 & 0.75 & 0.10 \\
\hline \multirow[t]{4}{*}{ Substrate } & General & 3 & 2 & 67 & 0.75 & 0.08 \\
\hline & Rubble & 11 & 5 & 45 & 0.72 & 0.07 \\
\hline & Sand & 2 & 2 & 100 & 0.85 & 0.02 \\
\hline & Silt/mud & 9 & 6 & 67 & 0.74 & 0.10 \\
\hline \multirow{4}{*}{$\begin{array}{l}\text { Reproductive } \\
\text { guild }\end{array}$} & External bearer & 1 & 1 & 100 & 0.93 & - \\
\hline & $\begin{array}{l}\text { Guarder, nest } \\
\text { spawner }\end{array}$ & 10 & 6 & 60 & 0.75 & 0.09 \\
\hline & $\begin{array}{l}\text { Non-guarder, } \\
\text { brood hider }\end{array}$ & 5 & 3 & 60 & 0.73 & 0.05 \\
\hline & $\begin{array}{l}\text { Non-guarder, } \\
\text { open substratum } \\
\text { spawner }\end{array}$ & 9 & 5 & 56 & 0.73 & 0.08 \\
\hline \multirow[t]{5}{*}{$\begin{array}{l}\text { Trophic feeding } \\
\text { guild }\end{array}$} & $\begin{array}{l}\text { Herbivore/ } \\
\text { detritivore }\end{array}$ & 1 & 0 & 0 & 0.61 & - \\
\hline & $\begin{array}{l}\text { Invertivore/ } \\
\text { piscivore }\end{array}$ & 10 & 5 & 50 & 0.73 & 0.09 \\
\hline & Invertivore & 7 & 7 & 100 & 0.81 & 0.07 \\
\hline & Omnivore & 6 & 2 & 33 & 0.70 & 0.03 \\
\hline & Piscivore & 1 & 1 & 100 & 0.78 & - \\
\hline \multirow[t]{9}{*}{ Family } & Catostomidae & 3 & 1 & 33 & 0.68 & 0.07 \\
\hline & Centrarchidae & 3 & 2 & 67 & 0.76 & 0.07 \\
\hline & Cottidae & 1 & 1 & 100 & 0.74 & - \\
\hline & Cyprinidae & 8 & 4 & 50 & 0.73 & 0.08 \\
\hline & Gasterosteidae & 1 & 1 & 100 & 0.75 & - \\
\hline & Ictaluridae & 3 & 2 & 67 & 0.74 & 0.15 \\
\hline & Percidae & 1 & 1 & 100 & 0.84 & - \\
\hline & Poeciliidae & 1 & 1 & 100 & 0.93 & - \\
\hline & Salmonidae & 4 & 2 & 50 & 0.73 & 0.06 \\
\hline
\end{tabular}


Table 3.4. Variable importance (delta deviance) of multivariate adaptive regression spline species distribution models (SDMs) developed in the Missouri (MRB) and Colorado (CRB) River basins by species and basin. Variable descriptions are available in Table 3.1 and species codes are in Table 3.2. Darker shading indicates higher values for each column. An asterisk (*) indicates species whose SDMs transferred from the CRB to MRB. Column subheadings MRB and CRB indicate the basin that SDMs were developed.

\begin{tabular}{|c|c|c|c|c|c|c|c|c|c|c|c|c|c|c|c|c|c|c|}
\hline \multirow{3}{*}{$\begin{array}{l}\text { Variable } \\
\text { Code }\end{array}$} & \multicolumn{18}{|c|}{ Species-Basin } \\
\hline & \multicolumn{2}{|c|}{ AMME* } & \multicolumn{2}{|c|}{ AMNA* } & \multicolumn{2}{|c|}{ CACA } & \multicolumn{2}{|c|}{ CACO ${ }^{*}$} & \multicolumn{2}{|c|}{ CAPT } & \multicolumn{2}{|c|}{ COBA* } & \multicolumn{2}{|c|}{ COPL* } & \multicolumn{2}{|c|}{ CUIN* } & \multicolumn{2}{|c|}{ CYCA* } \\
\hline & CRB & MRB & CRB & MRB & CRB & MRB & CRB & MRB & CRB & MRB & CRB & MRB & $\mathrm{CRB}$ & MRB & CRB & MRB & CRB & MRB \\
\hline SO & 0 & 37.1 & 73.5 & 0 & 0 & 0 & 0 & 0 & 39.8 & 0 & 40.9 & 0 & 0 & 0 & 34.7 & 30 & 45.3 & 51.6 \\
\hline L_Dam & 0 & 0 & 0 & 0 & 0 & 0 & 0 & 0 & 0 & 0 & 22.5 & 0 & 0 & 0 & 0 & 0 & 0 & 22.4 \\
\hline N_Crop & 100 & 31.9 & 0 & 0 & 0 & 0 & 50.6 & 24.2 & 26.3 & 37.9 & 0 & 100 & 0 & 27.5 & 88.4 & 26.3 & 48.7 & 57.1 \\
\hline N_Pop & 0 & 0 & 77.7 & 21 & 0 & 0 & 0 & 0 & 62 & 0 & 0 & 0 & 80.4 & 0 & 0 & 0 & 81 & 0 \\
\hline N_Dam & 10.2 & 0 & 0 & 26.1 & 14.2 & 0 & 23.8 & 50.9 & 0 & 42 & 0 & 0 & 0 & 14.1 & 64.3 & 0 & 0 & 100 \\
\hline N_Urban & 0 & 34.1 & 0 & 0 & 0 & 37.4 & 0 & 0 & 0 & 0 & 0 & 59.8 & 21.4 & 31.1 & 0 & 63.1 & 0 & 33.1 \\
\hline$\overline{B F I}$ & 13.2 & 100 & 48.2 & 32.6 & 23.9 & 60.4 & 17.1 & 56.6 & 0 & 95.4 & 32.7 & 76.2 & 48.8 & 54.2 & 82.4 & 5.1 & 73.9 & 39.1 \\
\hline Flow & 0 & 49.4 & 62.8 & 38.8 & 100 & 17.3 & 100 & 60.9 & 82.5 & 100 & 100 & 28.3 & 77.8 & 41.3 & 0 & 12.2 & 0 & 41.2 \\
\hline Velo & 0 & 18.3 & 0 & 11.6 & 48.3 & 100 & 50.7 & 7.1 & 43.1 & 0 & 27.9 & 0 & 72.9 & 5.2 & 38.8 & 0 & 20.1 & 0 \\
\hline Precip & 0 & 26.2 & 72.7 & 0 & 17.7 & 82.3 & 34.9 & 33.2 & 41 & 0 & 24.9 & 79.2 & 54.2 & 100 & 18 & 100 & 100 & 30.3 \\
\hline Temp & 16.3 & 69.2 & 100 & 100 & 36.6 & 0 & 61.9 & 100 & 41 & 92.4 & 70 & 63.3 & 95.4 & 28.7 & 0 & 58.9 & 71.8 & 75.7 \\
\hline Slope & 36.3 & 41.7 & 0 & 0 & 26.6 & 47.2 & 74.8 & 37 & 69.6 & 0 & 18.4 & 21.7 & 100 & 11.9 & 45.1 & 0 & 56 & 0 \\
\hline Lit19 & 32.3 & 0 & 38.2 & 0 & 0 & 0 & 29.4 & 0 & 0 & 0 & 0 & 0 & 0 & 0 & 0 & 8.9 & 0 & 36.3 \\
\hline Lit3 & 23.8 & 0 & 35.1 & 0 & 0 & 33.1 & 0 & 0 & 34.5 & 33.5 & 36.9 & 42.2 & 0 & 0 & 100 & 15.2 & 0 & 0 \\
\hline Lit5 & 0 & 0 & 58 & 0 & 41 & 26.7 & 0 & 0 & 100 & 0 & 0 & 0 & 37.6 & 0 & 0 & 0 & 0 & 0 \\
\hline
\end{tabular}


Table 3.4 (continued).

\begin{tabular}{|c|c|c|c|c|c|c|c|c|c|c|c|c|c|c|c|c|}
\hline \multirow[b]{3}{*}{ Variable } & \multicolumn{16}{|c|}{ Species-Basin } \\
\hline & \multicolumn{2}{|c|}{ CYLU* } & \multicolumn{2}{|c|}{ ETNI* } & \multicolumn{2}{|c|}{ GAAF* } & \multicolumn{2}{|c|}{ ICPU } & \multicolumn{2}{|c|}{ LECY* } & \multicolumn{2}{|c|}{ LEMA } & \multicolumn{2}{|c|}{ MISA* } & \multicolumn{2}{|c|}{ NOCR } \\
\hline & CRB & MRB & CRB & MRB & CRB & MRB & CRB & MRB & CRB & MRB & CRB & MRB & CRB & MRB & CRB & MRB \\
\hline SO & 15.6 & 0 & 0 & 0 & 0 & 14.9 & 0 & 26.3 & 0 & 0 & 0 & 0 & 0 & 0 & 0 & 0 \\
\hline L_Dam & 0 & 0 & 0 & 0 & 0 & 0 & 0 & 0 & 0 & 0 & 0 & 0 & 0 & 17.2 & 0 & 36.7 \\
\hline N_Crop & 0 & 44 & 100 & 60.7 & 62.7 & 28.8 & 0 & 0 & 60.2 & 0 & 41.3 & 17.1 & 100 & 24.8 & 0 & 62.7 \\
\hline N_Pop & 0 & 0 & 0 & 0 & 0 & 17.7 & 0 & 0 & 69.9 & 0 & 87.7 & 17.1 & 62.7 & 0 & 71 & 0 \\
\hline N_Dam & 0 & 0 & 0 & 0 & 0 & 31 & 0 & 100 & 0 & 0 & 0 & 14.6 & 0 & 19.7 & 38 & 0 \\
\hline N_Urban & 0 & 12.3 & 0 & 53.2 & 0 & 12.4 & 0 & 19.2 & 26.1 & 0 & 0 & 8.2 & 0 & 23.9 & 83.8 & 49.5 \\
\hline BFI & 93.9 & 33.3 & 0 & 100 & 77.6 & 0 & 100 & 33.1 & 64.2 & 28.8 & 35.3 & 31.4 & 0 & 39 & 30.3 & 35.7 \\
\hline Flow & 64 & 36.8 & 63.7 & 41.4 & 0 & 23.1 & 0 & 44.4 & 48.4 & 9.5 & 17.7 & 14.3 & 27.1 & 32.5 & 0 & 16.4 \\
\hline Velo & 0 & 18.5 & 0 & 12.2 & 0 & 20.4 & 67.6 & 39.4 & 0 & 7.5 & 0 & 9.5 & 42.9 & 14.2 & 0 & 0 \\
\hline Precip & 55.9 & 66.6 & 0 & 72.2 & 27 & 0 & 31.4 & 57.6 & 0 & 24.3 & 0 & 25.9 & 0 & 29.3 & 0 & 53.4 \\
\hline Temp & 100 & 100 & 0 & 48.2 & 100 & 100 & 0 & 64.4 & 100 & 100 & 100 & 100 & 72.4 & 100 & 100 & 100 \\
\hline Slope & 0 & 0 & 42.3 & 0 & 0 & 32.2 & 99.1 & 21.3 & 0 & 0 & 0 & 0 & 34.7 & 0 & 0 & 20 \\
\hline Lit19 & 0 & 14.2 & 0 & 0 & 21.4 & 45.1 & 39.6 & 15.5 & 0 & 0 & 0 & 0 & 38.3 & 0 & 0 & 0 \\
\hline Lit3 & 0 & 0 & 0 & 34.6 & 0 & 0 & 0 & 0 & 0 & 0 & 25.5 & 11.9 & 23.4 & 0 & 0 & 0 \\
\hline Lit5 & 0 & 0 & 0 & 0 & 0 & 0 & 0 & 0 & 30.4 & 0 & 0 & 0 & 9 & 0 & 0 & 0 \\
\hline
\end{tabular}


Table 3.4 (continued).

\begin{tabular}{|c|c|c|c|c|c|c|c|c|c|c|c|c|c|c|c|c|}
\hline \multirow[b]{3}{*}{ Variable } & \multicolumn{16}{|c|}{ Species-Basin } \\
\hline & \multicolumn{2}{|c|}{ NOST } & \multicolumn{2}{|c|}{ ONCL* } & \multicolumn{2}{|c|}{ ONMY } & \multicolumn{2}{|c|}{ PIPR } & \multicolumn{2}{|c|}{ RHCA* } & \multicolumn{2}{|c|}{ SAFO } & \multicolumn{2}{|c|}{ SATR* } & \multicolumn{2}{|c|}{ SEAT } \\
\hline & CRB & MRB & CRB & MRB & $\mathrm{CRB}$ & MRB & CRB & MRB & $\mathrm{CRB}$ & MRB & CRB & MRB & $\mathrm{CRB}$ & MRB & CRB & MRB \\
\hline SO & 0 & 32.8 & 30.3 & 6.6 & 43.9 & 37.5 & 49.6 & 0 & 0 & 0 & 10.6 & 0 & 32.2 & 16.3 & 75 & 0 \\
\hline L_Dam & 0 & 0 & 10.5 & 0 & 0 & 0 & 18.3 & 0 & 0 & 0 & 0 & 0 & 7.6 & 0 & 0 & 0 \\
\hline N_Crop & 100 & 17.9 & 0 & 0 & 32.9 & 0 & 87.4 & 30.3 & 36.5 & 42.3 & 0 & 0 & 0 & 47.9 & 34.4 & 9.4 \\
\hline N_Pop & 0 & 25.6 & 0 & 0 & 22 & 0 & 0 & 0 & 0 & 0 & 15.5 & 0 & 0 & 0 & 0 & 13.5 \\
\hline N_Dam & 0 & 29.8 & 0 & 0 & 0 & 0 & 100 & 13.1 & 73.3 & 25.3 & 18.3 & 0 & 0 & 0 & 0 & 29 \\
\hline N_Urban & 0 & 0 & 0 & 0 & 0 & 0 & 0 & 21.2 & 0 & 38.3 & 0 & 15 & 18.7 & 40.5 & 0 & 20.3 \\
\hline$\overline{B F I}$ & 0 & 40.2 & 18.6 & 28.9 & 14.9 & 100 & 75.3 & 82.5 & 0 & 54.9 & 13 & 34.2 & 49.1 & 73.8 & 63.5 & 33.6 \\
\hline Flow & 0 & 40.2 & 63.1 & 10 & 100 & 26.8 & 25.5 & 0 & 100 & 16 & 34.3 & 0 & 100 & 0 & 0 & 7.6 \\
\hline Velo & 0 & 8.7 & 27.1 & 8.7 & 0 & 72.4 & 49.6 & 6.8 & 58.9 & 66.7 & 0 & 17.5 & 0 & 100 & 12.1 & 10.3 \\
\hline Precip & 0 & 55.5 & 13.1 & 19.4 & 74.8 & 41.9 & 0 & 18.5 & 0 & 31.7 & 13.9 & 38.3 & 21.4 & 44.9 & 40.5 & 45.8 \\
\hline Temp & 0 & 100 & 100 & 100 & 52.5 & 52.2 & 28.7 & 100 & 19.6 & 100 & 100 & 100 & 38.1 & 54.4 & 75.9 & 100 \\
\hline Slope & 26.5 & 17.9 & 35.2 & 32.1 & 0 & 0 & 50.1 & 15.4 & 0 & 22.6 & 0 & 24.8 & 15.7 & 53.3 & 85.8 & 23.3 \\
\hline Lit19 & 22.9 & 12 & 0 & 0 & 27.3 & 14.7 & 0 & 0 & 39.4 & 0 & 20.3 & 8.1 & 0 & 0 & 55.1 & 0 \\
\hline Lit3 & 67.2 & 0 & 49.4 & 24 & 54.5 & 0 & 0 & 13.1 & 0 & 13.5 & 27.5 & 0 & 52.6 & 28.9 & 100 & 12.2 \\
\hline Lit5 & 0 & 0 & 24.1 & 12.2 & 54.5 & 23.8 & 39.3 & 13.1 & 31 & 0 & 11.8 & 19.7 & 44 & 32 & 17.1 & 0 \\
\hline
\end{tabular}




\section{Figures}
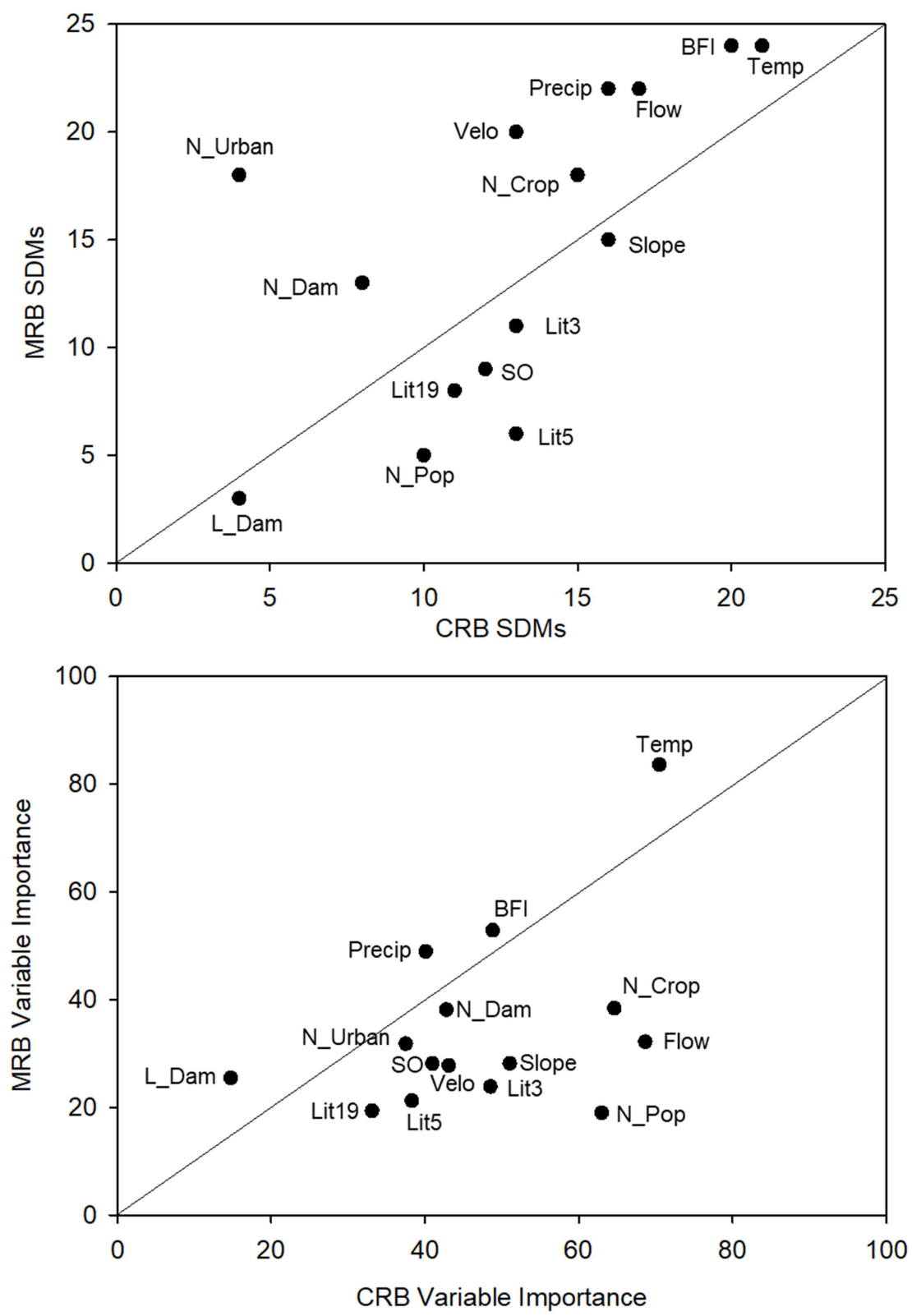

Figure 3.1. Number of multivariate adaptive regression spline species distribution models (SDMs) that a variable occurred (top) and mean importance (delta deviance) of variables that were included in SDMs (i.e., zeros excluded; bottom) for the Colorado (CRB) and Missouri (MRB) River basins. See Table 3.1 for variable code descriptions. Line approximates $1: 1$. 


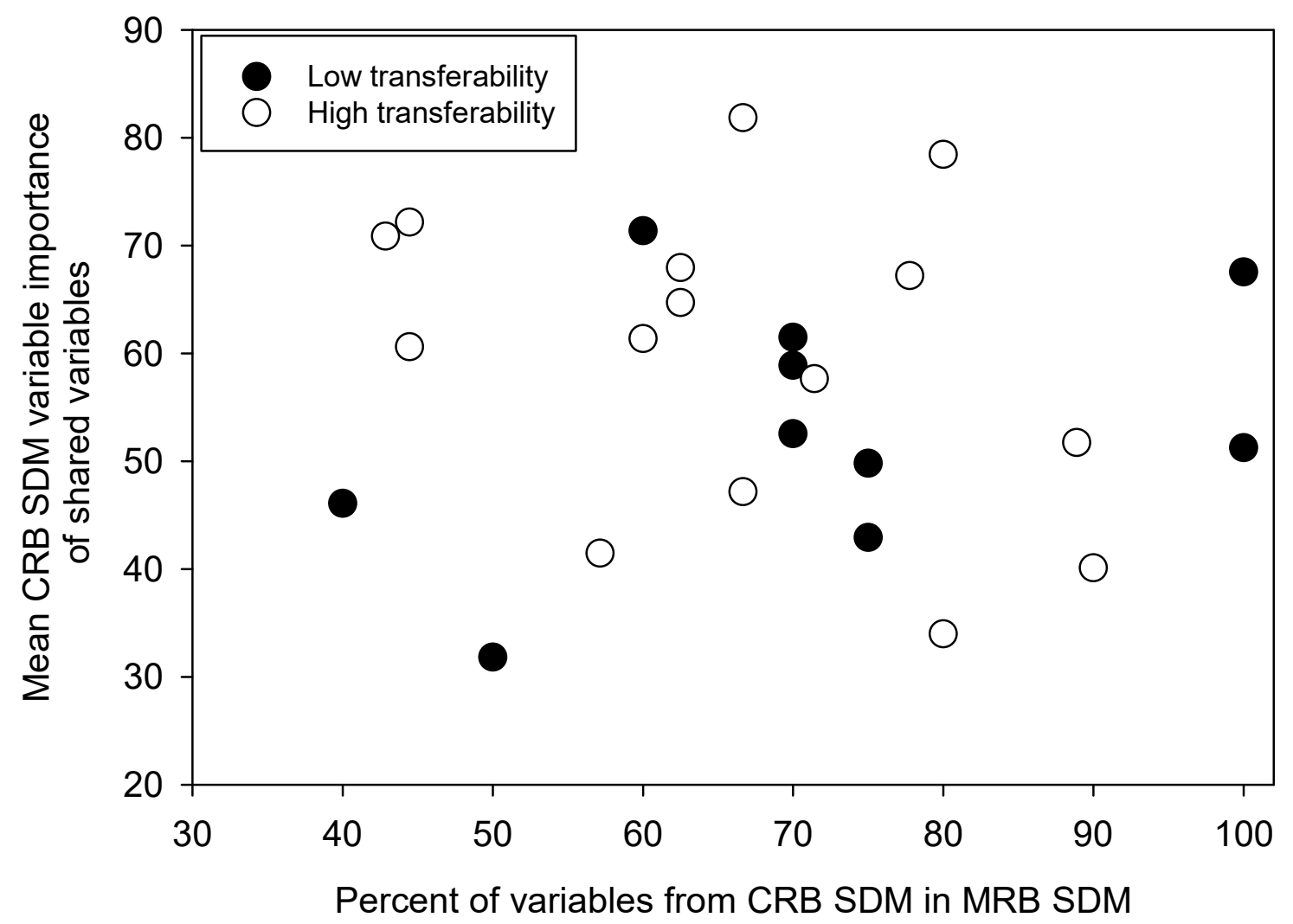

Figure 3.2. Percent of variables from multivariate adaptive regression spline species distribution models (SDMs) developed from Colorado River basin (CRB) data that were in Missouri River basin (MRB) SDMs (i.e., variable overlap) and mean variable importance (delta deviance) of variables in CRB SDMs for variables that occurred in SDMs for both basins. Each point represents one species and is labeled by MRB SDM transferability: low $=\mathrm{AUC}<0.7$, high $=\mathrm{AUC} \geq 0.7$. 


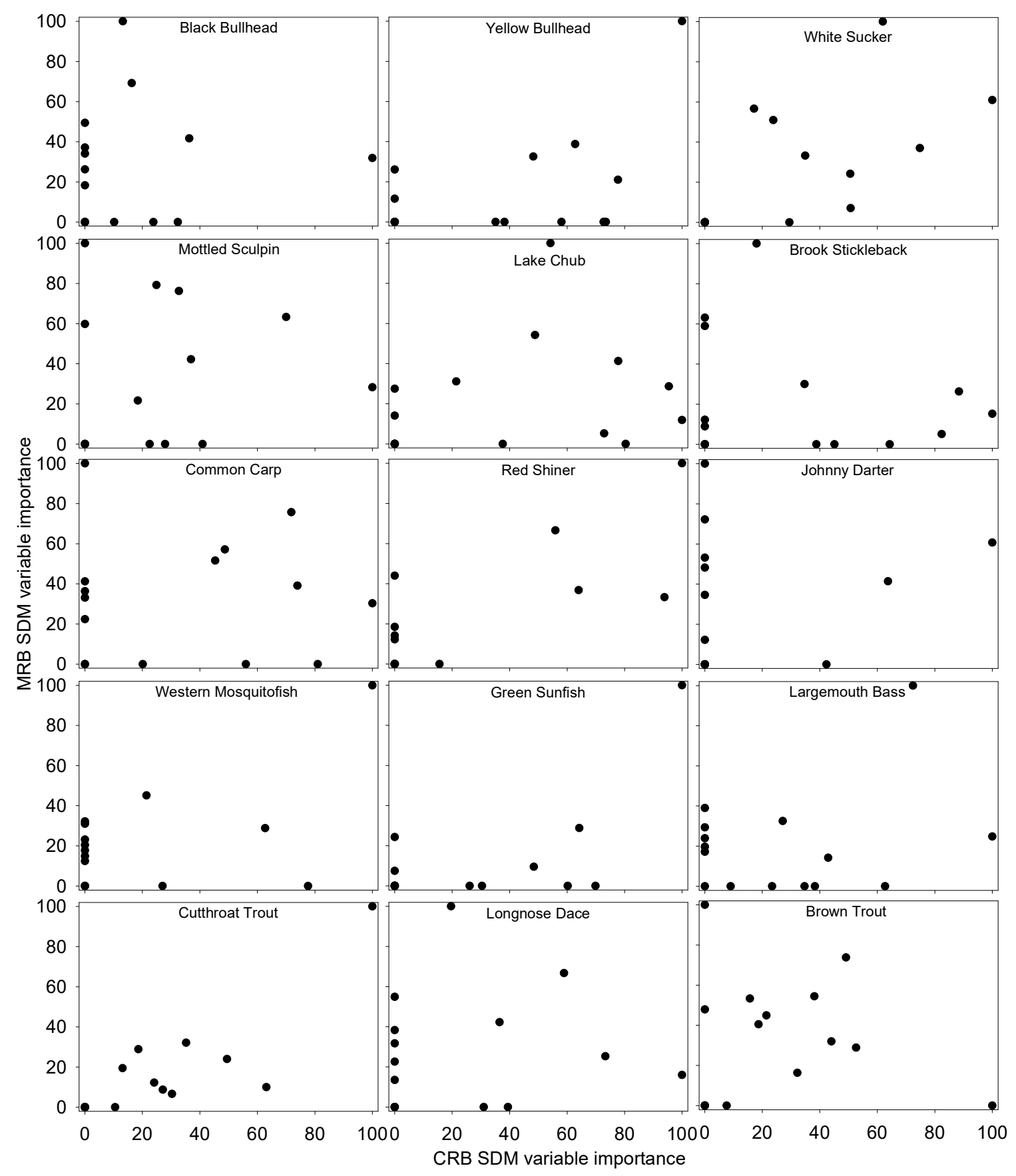

Figure 3.3. Variable importance (delta deviance) of multivariate adaptive regression spline species distribution models (SDMs) developed for the Colorado (CRB) and Missouri (MRB) River basins for species whose SDMs transferred from the MRB to CRB. 


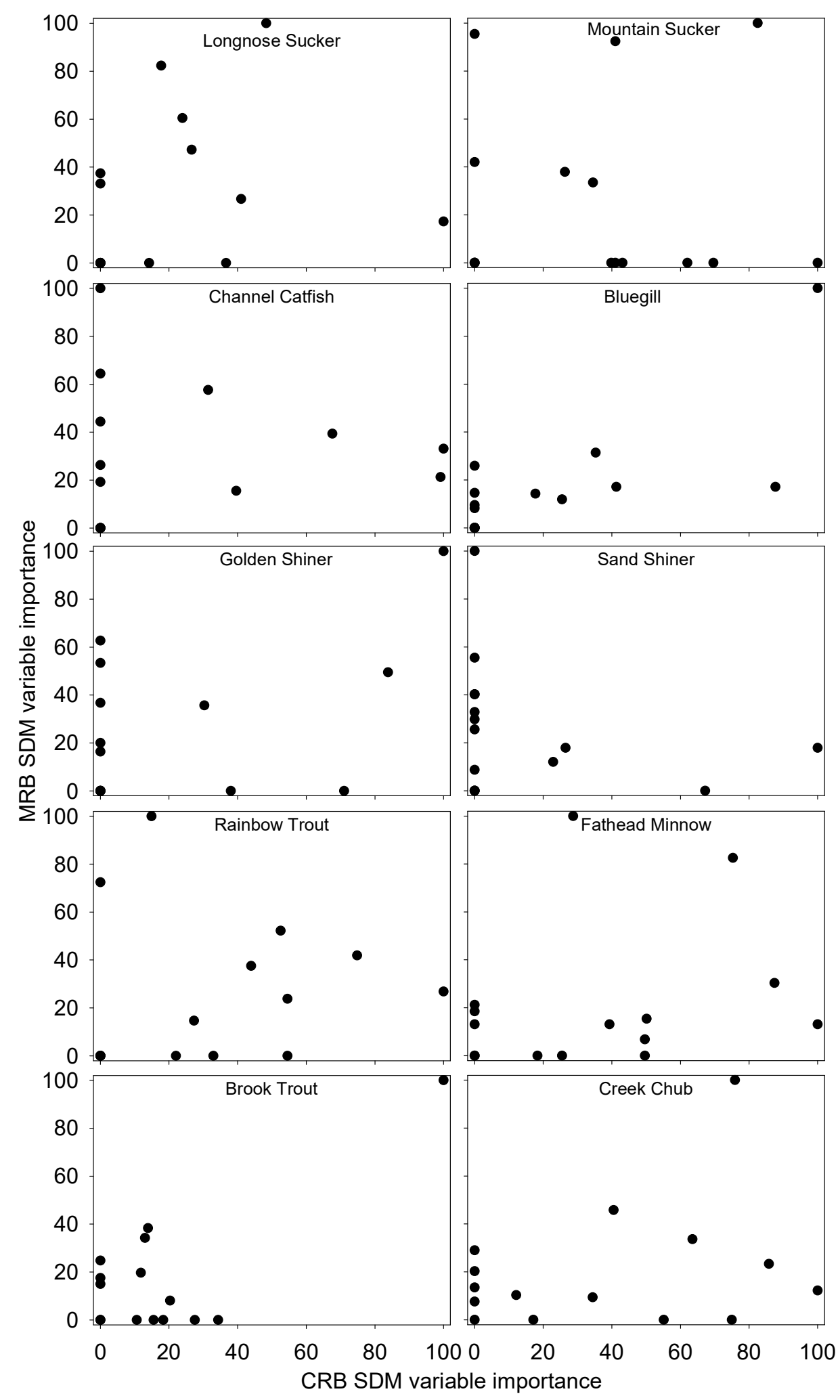

Figure 3.4. Variable importance of multivariate adaptive regression spline species distribution models (SDMs) developed for the Colorado (CRB) and Missouri (MRB) River basins for species whose SDMs did not transfer from the MRB to CRB. 


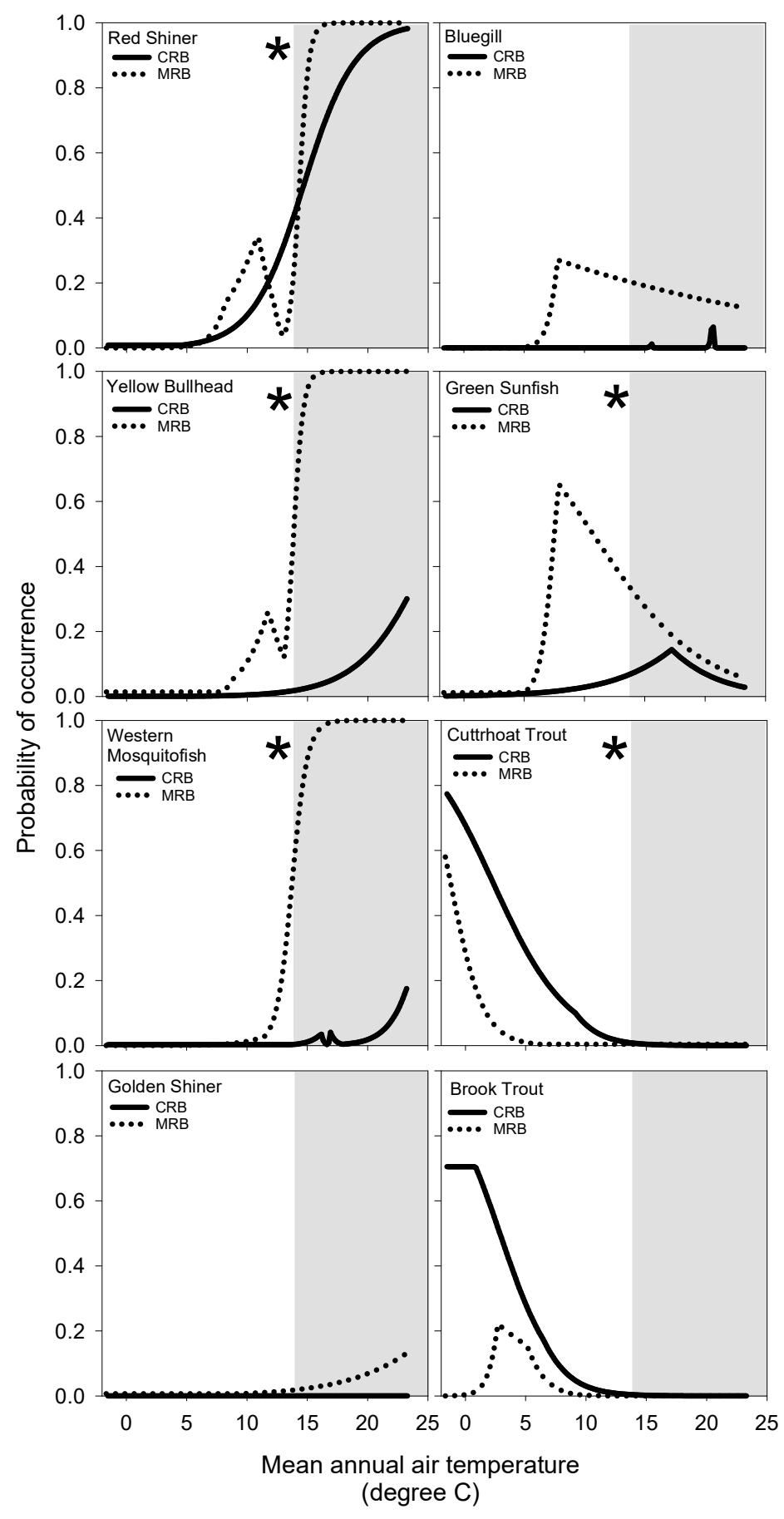

Figure 3.5. Predicted effect of mean annual air temperature on probability of occurrence for eight species whose most important variable in Colorado River (CRB) and Missouri River (MRB) basin multivariate adaptive regression spline species distribution models (SDMs) was mean annual temperature. Values represent the probability of occurrence at median values of all other environmental variables. Grey area represents temperatures available in CRB that are outside the temperature range available in the MRB. An asterisk (*) indicates species whose SDMs transferred from the MRB to the CRB. 


\section{Appendices}

Appendix 3.1. Mean variable importance of multivariate adaptive regression spline species distribution models (SDMs) developed in the Colorado (CRB) and Missouri (MRB) River basins by family and basin. Variable code descriptions are available in Table 3.1. Darker shading indicates higher values for each column. Column subheadings MRB and CRB indicate the basin that SDMs were developed.

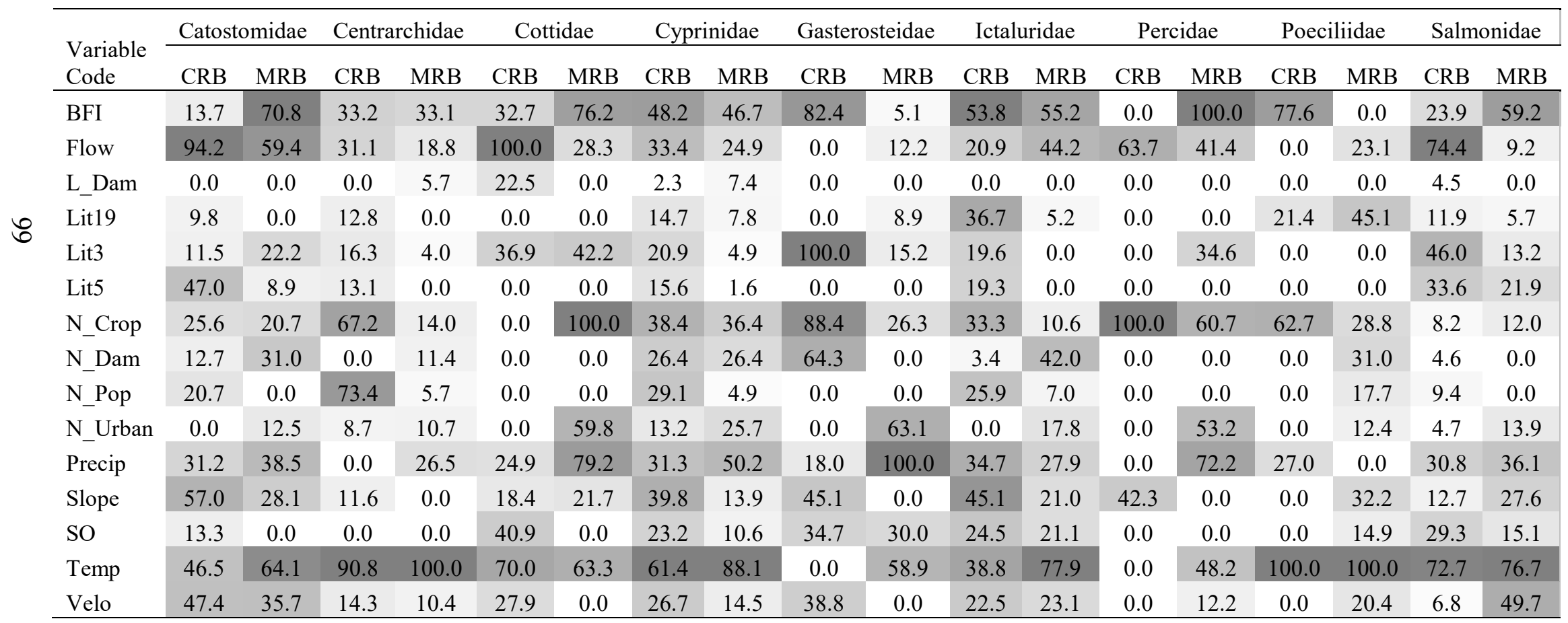


Appendix 3.2. Mean variable importance of multivariate adaptive regression spline species distribution models (SDMs) developed in the Colorado (CRB) and Missouri (MRB) River basins by species nativity and basin. Variable code descriptions are available in Table 3.1. Darker shading indicates higher values for each column. Column subheadings MRB and CRB indicate the basin that SDMs were developed.

\begin{tabular}{|c|c|c|c|c|c|c|c|c|}
\hline \multirow{3}{*}{$\begin{array}{l}\text { Variable } \\
\text { Code }\end{array}$} & \multicolumn{4}{|c|}{ CRB Nativity } & \multicolumn{4}{|c|}{ MRB Nativity } \\
\hline & \multicolumn{2}{|c|}{ Non-native } & \multicolumn{2}{|c|}{ Native } & \multicolumn{2}{|c|}{ Non-native } & \multicolumn{2}{|c|}{ Native } \\
\hline & $\mathrm{CRB}$ & MRB & $\mathrm{CRB}$ & MRB & $\mathrm{CRB}$ & MRB & $\mathrm{CRB}$ & MRB \\
\hline BFI & 42.0 & 48.6 & 17.1 & 66.8 & 45.7 & 49.4 & 37.4 & 51.1 \\
\hline Flow & 41.9 & 25.9 & 81.9 & 46.1 & 46.9 & 18.2 & 46.6 & 30.9 \\
\hline L_Dam & 1.2 & 3.5 & 11.0 & 0.0 & 1.5 & 4.5 & 2.6 & 2.7 \\
\hline Lit19 & 16.6 & 7.0 & & & & 20.8 & 14.8 & 2.5 \\
\hline Lit3 & & 7.4 & 40.3 & & & & 24.8 & 11.7 \\
\hline Lit5 & 17.0 & 5.2 & 41.4 & 4.1 & 22.1 & 15.1 & 19.4 & 2.6 \\
\hline N_Crop & 42.9 & 25.1 & 8.8 & 46.0 & 28.9 & 26.8 & 41.3 & 27.9 \\
\hline N_Dam & 15.6 & 20.6 & 0.0 & 14.0 & 3.7 & 26.2 & 16.2 & 18.2 \\
\hline N_Pop & 25.8 & & 20.7 & & 23.7 & & 25.6 & \\
\hline N_Urban & 6.8 & 23.3 & 0.0 & 19.9 & 3.7 & 20.2 & 6.6 & 23.6 \\
\hline Precip & 25.6 & 44.5 & 26.3 & 32.9 & 47.4 & 31.1 & 20.2 & 46.1 \\
\hline Slope & 31.5 & 16.8 & 41.1 & 17.9 & 14.3 & 22.1 & 37.2 & 15.6 \\
\hline so & 17.3 & 11.2 & 37.0 & 2.2 & 26.4 & 24.1 & 18.0 & 6.6 \\
\hline Temp & 57.7 & 79.6 & 70.3 & 85.2 & 72.5 & 76.5 & 55.9 & 81.3 \\
\hline Velo & 21.0 & 24.8 & 32.7 & 2.9 & 4.0 & 42.1 & 27.0 & 17.2 \\
\hline
\end{tabular}


Appendix 3.3. Mean variable importance of multivariate adaptive regression spline species distribution models (SDMs) developed in the Colorado (CRB) and Missouri (MRB) River basins by feeding guild and basin. Variable code descriptions are available in Table 3.1. Darker shading indicates higher values for each column. Column subheadings MRB and CRB indicate the basin that SDMs were developed.

\begin{tabular}{|c|c|c|c|c|c|c|c|c|c|c|}
\hline \multirow{2}{*}{$\begin{array}{l}\text { Variable } \\
\text { Code }\end{array}$} & \multicolumn{2}{|c|}{ Herbivore/ detritivore } & \multicolumn{2}{|c|}{$\begin{array}{c}\text { Invertivore/ } \\
\text { piscivore }\end{array}$} & \multicolumn{2}{|c|}{ Invertivore } & \multicolumn{2}{|c|}{ Omnivore } & \multicolumn{2}{|c|}{ Piscivore } \\
\hline & $\mathrm{CRB}$ & MRB & CRB & MRB & $\mathrm{CRB}$ & MRB & $\mathrm{CRB}$ & MRB & $\mathrm{CRB}$ & MRB \\
\hline BFI & 0.0 & 95.4 & 42.0 & 49.6 & 47.9 & 46.2 & 36.8 & 52.4 & 0.0 & 39.0 \\
\hline Flow & 82.5 & 100.0 & 42.6 & 20.1 & 57.9 & 28.4 & 37.6 & 29.3 & 27.1 & 32.5 \\
\hline L_Dam & 0.0 & 0.0 & 1.8 & 0.0 & 3.2 & 0.0 & 3.1 & 9.9 & 0.0 & 17.2 \\
\hline Lit19 & 0.0 & 0.0 & 21.3 & 3.8 & 8.7 & 9.7 & 8.7 & 8.1 & 38.3 & 0.0 \\
\hline Lit3 & 34.5 & 33.5 & 36.8 & 7.7 & 19.6 & 15.1 & 11.2 & 7.7 & 23.4 & 0.0 \\
\hline Lit5 & 100.0 & 0.0 & 24.0 & 8.8 & 9.8 & 0.0 & 13.4 & 6.6 & 9.0 & 0.0 \\
\hline N_Crop & 26.3 & 37.9 & 26.9 & 10.6 & 41.1 & 47.1 & 47.8 & 32.0 & 100.0 & 24.8 \\
\hline N_Dam & 0.0 & 42.0 & 2.9 & 17.0 & 19.7 & 10.1 & 29.3 & 32.3 & 0.0 & 19.7 \\
\hline N_Pop & 62.0 & 0.0 & 27.3 & 5.2 & 11.5 & 2.5 & 25.3 & 4.3 & 62.7 & 0.0 \\
\hline N_Urban & 0.0 & 0.0 & 4.5 & 13.7 & 3.1 & 38.6 & 14.0 & 23.5 & 0.0 & 23.9 \\
\hline Precip & 41.0 & 0.0 & 26.8 & 32.4 & 25.7 & 64.2 & 25.4 & 45.5 & 0.0 & 29.3 \\
\hline Slope & 69.6 & 0.0 & 27.2 & 19.7 & 29.4 & 12.6 & 39.0 & 22.9 & 34.7 & 0.0 \\
\hline SO & 39.8 & 0.0 & 26.6 & 12.4 & 13.0 & 6.4 & 15.8 & 14.1 & 0.0 & 0.0 \\
\hline Temp & 41.0 & 92.4 & 68.3 & 84.0 & 55.0 & 71.3 & 49.8 & 79.3 & 72.4 & 100.0 \\
\hline Velo & 43.1 & 0.0 & 10.7 & 29.5 & 28.4 & 17.6 & 28.1 & 20.4 & 42.9 & 14.2 \\
\hline
\end{tabular}


Appendix 3.4. Mean variable importance of multivariate adaptive regression spline species distribution models (SDMs) developed in the Colorado (CRB) and Missouri (MRB) River basins by substrate preference and basin. Variable code descriptions are available in Table 3.1. Darker shading indicates higher values for each column. Column subheadings MRB and CRB indicate the basin that SDMs were developed.

\begin{tabular}{lccccccccc}
\hline \multirow{2}{*}{$\begin{array}{l}\text { Variable } \\
\text { Code }\end{array}$} & \multicolumn{2}{c}{ General } & \multicolumn{2}{c}{ Rubble } & \multicolumn{2}{c}{ Sand } & \multicolumn{2}{c}{ Silt/mud } \\
\cline { 2 - 9 } CRB & MRB & CRB & MRB & CRB & MRB & CRB & MRB \\
\hline BFI & 48.8 & 40.4 & 24.0 & 57.3 & 24.4 & 77.1 & 57.4 & 40.4 \\
Flow & 60.6 & 37.3 & 67.5 & 25.9 & 70.8 & 41.4 & 11.2 & 25.4 \\
L_Dam & 0.0 & 0.0 & 3.7 & 0.0 & 0.0 & 0.0 & 2.0 & 8.5 \\
Lit19 & 9.8 & 4.7 & 18.5 & 3.2 & 0.0 & 0.0 & 14.6 & 11.8 \\
Lit3 & 8.5 & 4.0 & 41.6 & 17.0 & 0.0 & 17.3 & 16.4 & 3.1 \\
Lit5 & 0.0 & 0.0 & 34.7 & 10.4 & 18.8 & 0.0 & 8.7 & 1.5 \\
N_Crop & 30.6 & 28.4 & 20.9 & 23.2 & 50.0 & 44.1 & 60.8 & 29.1 \\
N_Dam & 7.9 & 21.8 & 9.6 & 13.8 & 0.0 & 7.1 & 23.6 & 29.3 \\
N_Pop & 29.2 & 5.7 & 16.1 & 5.5 & 40.2 & 0.0 & 31.6 & 2.0 \\
N_Urban & 0.0 & 6.8 & 1.7 & 19.2 & 10.7 & 42.2 & 12.2 & 28.5 \\
Precip & 30.3 & 41.9 & 29.1 & 39.9 & 27.1 & 86.1 & 19.6 & 37.7 \\
Slope & 24.9 & 12.3 & 25.3 & 22.1 & 71.2 & 6.0 & 35.7 & 14.5 \\
SO & 5.2 & 0.0 & 31.5 & 8.5 & 0.0 & 0.0 & 14.4 & 17.8 \\
Temp & 87.3 & 100.0 & 57.6 & 78.4 & 47.7 & 38.5 & 54.4 & 85.4 \\
Velo & 16.9 & 11.7 & 19.8 & 36.0 & 36.5 & 8.7 & 24.3 & 11.8 \\
\hline
\end{tabular}


Appendix 3.5. Mean variable importance of multivariate adaptive regression spline species distribution models (SDMs) developed in the Colorado (CRB) and Missouri (MRB) River basins by temperature preference and basin. Variable code descriptions are available in Table 3.1. Darker shading indicates higher values for each column. Column subheadings MRB and CRB indicate the basin that SDMs were developed.

\begin{tabular}{lcccccc}
\hline \multirow{2}{*}{$\begin{array}{l}\text { Variable } \\
\text { Code }\end{array}$} & \multicolumn{2}{c}{ Cold } & \multicolumn{2}{c}{ Cool } & \multicolumn{2}{c}{ Warm } \\
\cline { 2 - 7 } & CRB & MRB & CRB & MRB & CRB & MRB \\
\hline BFI & 25.7 & 62.6 & 29.5 & 57.5 & 51.0 & 41.3 \\
Flow & 79.5 & 13.0 & 65.5 & 37.1 & 20.5 & 28.9 \\
L_Dam & 8.1 & 0.0 & 0.0 & 0.0 & 1.5 & 6.4 \\
Lit19 & 9.5 & 4.6 & 15.5 & 1.1 & 16.1 & 10.3 \\
Lit3 & 44.2 & 19.0 & 29.3 & 17.8 & 14.6 & 2.1 \\
Lit5 & 26.9 & 17.5 & 28.3 & 3.3 & 11.4 & 1.1 \\
N_Crop & 6.6 & 29.6 & 42.0 & 28.5 & 50.0 & 26.2 \\
N_Dam & 3.7 & 0.0 & 22.0 & 20.2 & 12.4 & 27.9 \\
N_Pop & 7.5 & 0.0 & 17.8 & 1.7 & 37.5 & 6.8 \\
N_Urban & 3.7 & 23.1 & 2.7 & 30.4 & 9.2 & 17.8 \\
Precip & 29.6 & 44.7 & 25.8 & 58.2 & 23.9 & 32.3 \\
Slope & 13.9 & 26.4 & 55.5 & 17.8 & 25.2 & 12.4 \\
SO & 31.6 & 12.1 & 18.7 & 3.8 & 15.3 & 13.6 \\
Temp & 72.1 & 74.0 & 41.3 & 66.0 & 65.8 & 92.4 \\
Velo & 11.0 & 39.7 & 40.6 & 25.2 & 15.0 & 12.9 \\
\hline
\end{tabular}


Appendix 3.6. Mean variable importance of multivariate adaptive regression spline species distribution models (SDMs) developed in the Colorado (CRB) and Missouri (MRB) River basins by reproductive guild and basin. Variable code descriptions are available in Table 3.1. Darker shading indicates higher values for each column. Column subheadings MRB and CRB indicate the basin that SDMs were developed.

\begin{tabular}{|c|c|c|c|c|c|c|c|c|}
\hline \multirow{2}{*}{$\begin{array}{l}\text { Variable } \\
\text { Code }\end{array}$} & \multicolumn{2}{|c|}{ External bearer } & \multicolumn{2}{|c|}{$\begin{array}{l}\text { Guarder, nest- } \\
\text { spawner }\end{array}$} & \multicolumn{2}{|c|}{$\begin{array}{c}\text { Non-guarder, } \\
\text { brood hider }\end{array}$} & \multicolumn{2}{|c|}{$\begin{array}{l}\text { Non-guarder, oper } \\
\text { substrate }\end{array}$} \\
\hline & $\mathrm{CRB}$ & MRB & CRB & MRB & $\mathrm{CRB}$ & MRB & $\mathrm{CRB}$ & MRB \\
\hline BFI & 77.6 & 0.0 & 48.2 & 48.6 & 25.7 & 62.6 & 32.0 & 52.2 \\
\hline Flow & 0.0 & 23.1 & 24.5 & 25.0 & 79.5 & 13.0 & 58.3 & 41.1 \\
\hline L_Dam & 0.0 & 0.0 & 1.8 & 1.7 & 8.1 & 0.0 & 0.0 & 6.6 \\
\hline Lit19 & 21.4 & 45.1 & 20.4 & 2.4 & 9.5 & 4.6 & 10.2 & 6.9 \\
\hline Lit3 & 0.0 & 0.0 & 30.8 & 8.7 & 44.2 & 19.0 & 11.3 & 8.9 \\
\hline Lit5 & 0.0 & 0.0 & 15.4 & 1.3 & 26.9 & 17.5 & 23.3 & 3.0 \\
\hline N_Crop & 62.7 & 28.8 & 61.2 & 20.1 & 6.6 & 29.6 & 29.1 & 34.8 \\
\hline N_Dam & 0.0 & 31.0 & 17.5 & 20.3 & 3.7 & 0.0 & 16.6 & 29.1 \\
\hline N_Pop & 0.0 & 17.7 & 29.8 & 5.2 & 7.5 & 0.0 & 32.7 & 2.8 \\
\hline N_Urban & 0.0 & 12.4 & 2.6 & 24.3 & 3.7 & 23.1 & 11.7 & 22.4 \\
\hline Precip & 27.0 & 0.0 & 16.3 & 40.0 & 29.6 & 44.7 & 33.7 & 50.3 \\
\hline Slope & 0.0 & 32.2 & 39.3 & 10.2 & 13.9 & 26.4 & 39.3 & 17.4 \\
\hline SO & 0.0 & 14.9 & 23.3 & 9.3 & 31.6 & 12.1 & 11.2 & 9.4 \\
\hline Temp & 100.0 & 100.0 & 49.3 & 84.1 & 72.1 & 74.0 & 58.5 & 77.4 \\
\hline Velo & 0.0 & 20.4 & 21.1 & 13.0 & 11.0 & 39.7 & 32.7 & 22.9 \\
\hline
\end{tabular}




\title{
CHAPTER 4- FAMILY-LEVEL EVALUATION OF THE DRIVERS OF NON-NATIVE LOTIC FISH ESTABLISHMENT
}

\begin{abstract}
Non-native species are a primary factor leading to the decline of native fish species, and prevention of their establishment is often the most cost-effective control method for managing their effects on ecosystems. Human activity, biotic resistance, and biotic acceptance are three hypothesized drivers of non-native species establishment, but the drivers of non-native lotic fish species establishment are relatively unclear, potentially due to spatial and taxonomic scales of previous analyses. Therefore, we evaluated the Human Activity, Biotic Resistance, and Biotic Acceptance hypotheses for lotic fishes in the Missouri and Colorado River Basins at the "global" [i.e., Missouri and Colorado River basins (MRB and CRB, respectively) combined] and physiographic province spatial extents and family taxonomic level. Specifically, we evaluated the effects of human activity, biotic resistance and biotic acceptance metrics on the probability of nonnative fish family occurrences with logistic regression for three families: Salmonidae, Catostomidae, and Cyprinidae. The drivers of non-native Salmonidae presence varied among spatial extents, but these hypotheses explained little variability in non-native Salmonidae presence (pseudo- $R^{2}<0.2$ ). Biotic Resistance and Biotic Acceptance hypotheses were the most-supported models of non-native Cyprinidae presence, but the variables that best explained non-native Cyprinidae presence differed between regions and only explained significant variability in one of five spatial extents (pseudo- $R^{2} \geq 0.2$ ). Finally, the drivers of non-native Catostomidae presence varied among spatial extents, as
\end{abstract}


the Human Activity Hypothesis received the most support at the global extent and in the Intermontane Plateau physiographic division of the CRB, but the Biotic Acceptance Hypothesis was supported for the Interior Plains physiographic division of the MRB and Rocky Mountain System physiographic division (MRB and CRB). The hypothesized drivers generally explained little variability in non-native family occurrence, which may suggest that other factors (e.g., natural abiotic factors) are likely important drivers of nonnative species at the spatial and taxonomic scales we considered. We suggest that considering non-native species invasions as a stepwise process within a hierarchical habitat filtering framework may provide valuable insight on the drivers of invasions, such as explaining variability in the drivers of invasions among spatial scales and species.

\section{Introduction}

Understanding the drivers of non-native fish establishment is critical to the conservation of native lotic fishes. Non-native species are a primary threat to native species and were implicated in the imperilment and extinction of numerous native lotic fishes (Miller et al. 1989; Tyus and Saunders 2000; Malmqvist and Rundle 2002). The threat posed by non-native fishes has likely increased recently in the USA because nonnative fish species richness was predicted to increase from 69 in 1990 to 150 in 2025 (Malmqvist and Rundle 2002). However, identification of the factors that lead to nonnative species establishment can reduce this threat by allowing areas with a high probability of establishment to be targeted for prevention efforts. The ability to identify and prioritize areas for prevention efforts is particularly valuable because prevention is often the most cost-effective approach for managing non-native species (Wittenberg and Cock 2001). Therefore, knowledge of the drivers of non-native species establishment is 
critical to effective control of non-native species invasions and, subsequently, conservation of native fishes.

Three commonly evaluated hypotheses of the drivers of non-native species establishment are "Human Activity", "Biotic Acceptance", and "Biotic Resistance" (Olden et al. 2010). The Human Activity Hypothesis suggests that human activities promote non-native species by increasing propagule pressure (i.e., the number of species introductions or number of individuals introduced) and habitat alteration (Olden et al. 2010). The Biotic Acceptance Hypothesis suggests that environmental conditions that support a high diversity of native species will also support a high diversity of non-native species (Fridley et al. 2007). Finally, the Biotic Resistance Hypothesis predicts that ecosystems with high native species richness will be more resistant to non-native species (via competition and predation) than ecosystems with low native species richness, and therefore, will have fewer non-native species (Levine and D'Antonio 1999).

Currently, however, the drivers of non-native fish establishment are unclear, potentially due to different drivers among spatial scales or geographic regions. Dos Santos et al. (2018) indicated that an invasion paradox exists because there is support for two competing hypotheses (i.e., Biotic Resistance and Biotic Acceptance hypotheses) across taxa. These authors suggested that the paradox could be partially resolved by considering spatial scale because the Biotic Resistance Hypothesis is generally supported at small spatial scales (e.g., experimental scales) and the Biotic Acceptance Hypothesis tends to be supported at large spatial scales, though this pattern was primarily observed for terrestrial plants. Freshwater fish, however, may follow a different pattern because the Human Activity and Biotic Acceptance hypotheses have received support at multiple 
spatial scales (Gido and Brown 1999; Meador et al. 2003; Marchetti et al. 2004; Light and Marchetti 2007; Leprieur et al. 2008; Blanchet et al. 2009; Hermoso et al. 2011; dos Santos et al. 2018). Furthermore, although negative relationships between native species richness and non-native species have been observed (e.g., Meador et al. 2003; Mitchell and Knouft 2009), it is difficult to determine whether these relationships represent Biotic Resistance, the negative effect of non-native species on native species, or differences in the number of non-native species introductions between areas (e.g. Gido et al. 2004). The lack of broad patterns in the drivers of non-native fish invasions may also be the result of different drivers (e.g., Blanchet et al. 2009) or colonization opportunities (Gido et al. 2004) between regions. For example, Ruesink (2005) indicated that invasion success increased with endemism of the native fish fauna, which suggests that invasion success varies regionally because endemism varies regionally.

The drivers of non-native species invasions may also be unclear because most studies evaluated the drivers of non-native species richness and were limited by the assumption that drivers were consistent across species (Lapointe and Light 2012). As a result, species with different functional traits were expected to interact similarly with the environment and native fish assemblage. This assumption, however, may be invalid in some studies because multiple studies across taxa have shown that establishment of nonnative species differs between families and based on species characteristics (Kolar and Lodge 2001; Kolar and Lodge 2002; Ruesink 2005). For example, Ruesink (2005) found that establishment was higher for fish species in families with small body size and for omnivores. Given this uncertainty of the primary drivers of non-native fish invasions, 
additional research is needed to identify regional and taxonomic differences in the drivers of non-native lotic fish distributions.

To improve our understanding of the drivers of non-native lotic fish establishment, we evaluated the Biotic Resistance, Biotic Acceptance, and Human Activity hypotheses for non-native fishes at the family taxonomic level. The family taxonomic level likely provides more insight into these hypotheses than species richness because phylogenetically similar species possess similar traits (Whitney et al. 2017) and, therefore, likely respond similarly to environmental variability (Frimpong and Angermeier 2010b). This approach is likely particularly informative for evaluating Biotic Resistance and Biotic Acceptance hypotheses because it allows us to examine if native species exclude closely-related non-native species or if they serve as indicators of suitable habitat for closely-related non-native species. Furthermore, evaluating the drivers of non-native fishes at the family taxonomic level is consistent with Lapointe and Light (2012) who indicated that consideration of species identity can improve our understanding of ecosystem invasability, and with Ruesink (2005) who found that establishment was higher for species in families characterized by small body size. Finally, this family-level approach provides generality for predicting species invasions across large spatial extents where the species identity (i.e., species) of potential invaders may be unknown.

\section{Methods}

\section{Study Site}

We evaluated the Biotic Resistance, Biotic Acceptance, and Human Activity hypotheses for small streams (i.e., 1st - 4th order; USEPA 2005) in the Colorado and 
Missouri River basins ( $\mathrm{CRB}$ and MRB, respectively). These basins provided a unique opportunity to evaluate the drivers of species invasions across a wide range of environmental (e.g. arid to humid, Rocky Mountain to Great Plains terrestrial ecosystems) and fish assemblage (e.g., native and non-native species richness) variability.

The CRB spans approximately $632,000 \mathrm{~km}^{2}$ in southwestern USA and northwestern Mexico (Figure 4.1; Carlson and Muth 1989; Olden et al. 2006). The CRB is divided into the upper (UCRB) and lower Colorado River Basin (LCRB) at Glen Canyon Dam, AZ for water management purposes (Olden et al. 2006). The CRB is primarily semi-arid shrub lands and desert shrubs, and the large rivers of the basin flow primarily through highly erodible, sedimentary deposits (Tyus et al. 1982; Blinn and Poff 2005). Mean annual precipitation is $22.1 \mathrm{~cm} / \mathrm{yr}$ in the UCRB and 10.6 in the LCRB (Blinn and Poff 2005). The CRB is primarily comprised of the Intermountain Plateaus physiographic division, but also contains the Rocky Mountain System physiographic division (Figure 4.1; Fenneman and Johnson 1946). The CRB has a unique fish fauna that consists of 36 native fish species (including 3 marine or brackish species), of which 23 are endemic (Carlson and Muth 1989). However, the distributions and abundances of native fish species have been reduced by altered stream flows, non-native species introductions, reduced water quality, and habitat alteration (Tyus et al. 1982; Carlson and Muth 1989; Valdez and Muth 2005; Kominoski et al. 2018). Approximately 50 nonnative species are present in the UCRB (Valdez and Muth 2005). Meanwhile, over 80 non-native species have been introduced to the LCRB, and more than 20 non-native species are relatively common (Minckley and Deacon 1991; Mueller et al. 2005). 
The MRB is the second largest river basin in the USA, draining approximately $1,371,017 \mathrm{~km}^{2}$ in the USA and $25,100 \mathrm{~km}^{2}$ in Canada (Figure 4.1; Galat et al. 2005b). The MRB headwaters originate from the Rocky Mountains at elevations of approximately 1,200 to 4,400 $\mathrm{m}$ (Galat et al. 2005a). The MRB is primarily comprised of the semi-arid (36 cm mean annual precipitation) Interior Plains physiographic division, but also includes the Rocky Mountain System ( $>80 \mathrm{~cm}$ mean annual precipitation) and Interior Highlands (> $100 \mathrm{~cm}$ mean annual precipitation) physiographic divisions (Figure 4.1; Fenneman and Johnson 1946; Galat et al. 2005b). The MRB has 138 native and 35 non-native fish species (Galat et al. 2005b). Only two species, the Niangua darter Etheostoma nianguae and bluestripe darter Percina cymatotaenia are endemic (Cross et al. 1986; Galat et al 2005b). Although the MRB has been subjected to numerous anthropogenic threats (e.g., land use change, impoundments), the native fish fauna of the MRB has remained relatively intact (Galat et al. 2005b).

\section{Fish Distribution Data}

We summarized geo-referenced fish occurrence data for small streams in the CRB and MRB collected between 1990 and 2012. Occurrence data was a compilation of state and federal agency fish collection databases, university and museum collections, and gray literature originally compiled by Annis et al. (2010), Whittier et al. (2011), and Whittier and Sievert (2014). Fish samples were linked to National Hydrography Dataset (NHDPlus Version 1; USEPA and USGS 2005) stream segments using a spatial join in ArcGIS (ESRI 2009). Stream segments are generally lengths of stream between tributary confluences but may be shorter if side channels, divergences, or other features occur (McKay et al. 2012). Samples that did not capture any fish were excluded from our 
analysis. All sample records for each stream segment were combined and summarized to native species richness and presence-absence by nativity at the family taxonomic level (e.g., presence-absence of non-native Salmonidae, and presence- absence of native Salmonidae) for our analyses.

Nativity of fish species was determined for each basin and sub-basin based on Cross et al. (1986) for the MRB and Minckley et al. (1986) for the CRB (Appendix 4.1). These sub-basins were the Upper Missouri River, Yellowstone River, White-Little Missouri Rivers, Platte-Niobrara Rivers, James-Sioux Rivers, Chariton-Nishnabotna Rivers, Kansas River, and Lower Missouri River for the MRB, and the UCRB, Middle CRB (MCRB), and LCRB for the CRB (Figure 4.1). We represented the sub-basins from Cross et al. (1986) and Minckley et al. (1986) using 4-digit HUC regions from the NHDplus watershed boundary data layer. We considered the Bill Williams basin part of the LCRB because Minckley et al. (1986) considered most of the Bill Williams basin to be LCRB but indicated that some parts of the basin may be MCRB. Species were assumed to be non-native if they were identified as "uncertain" nativity or omitted by Cross et al. (1986) and Minckley et al. (1986). Subspecies were considered the parent species for nativity assignment and data summarization. We considered the parent species to be native in any sub-basins that a subspecies was native.

\section{Environmental Data}

We acquired and summarized landscape-level data of potential anthropogenic disturbances to represent Human Activity Hypothesis independent variables in our analyses. Landscape-level factors were quantified for the upstream watershed ("network" scale) and local catchments ("local" scale) of stream segments. Metrics of human activity 
included cultivated crop and urban land uses, dam storage density, dam density, population density, and three disturbance indices (local scale, network scale, and cumulative scale that incorporates disturbances at the local and network scales; Esselman et al. 2011b). Disturbance indices explained the risk of current habitat alteration to fluvial habitats and ranged from 1 (highest risk) to 5 (lowest risk; Esselman et al. 2011a; Esselman et al. 2011b). Values for land use, number of dams, population density, and disturbance indices were acquired from the National Fish Habitat Action Plan (NFHAP) 2010 Habitat Condition Index Scores and Human Disturbance Data for Conterminous United States database (Esselman et al. 2011a). We combined low, medium, and high intensity urban land uses into a total urban land use value. We quantified dam storage density using the Catchment Attribute Allocation and Accumulation Tool (http://www.horizon-systems.com/nhdplus/NHDPlusV1 tools.php) and dam storage data from the 2010 National Inventory of Dams database (USACE 2010). We acquired local catchment and upstream watershed area $\left(\mathrm{km}^{2}\right)$ values from Esselman et al. (2011a) and calculated dam density as number dams/ area (i.e., catchment or network) and dam storage density as total reservoir storage capacity/ area (i.e., catchment or watershed). We identified correlated human activity metrics using Spearman's correlation analysis and removed metrics that were correlated $\left(r_{s} \geq|0.6|\right)$ with other human activity metrics. If a metric type (e.g., crop land use) was strongly correlated between spatial scales (i.e., local, network, cumulative), then we retained the largest spatial scale for analysis.

\section{Data Analysis}

We evaluated Biotic Resistance, Biotic Acceptance, and Human Activity hypotheses as drivers of non-native fish family occurrence with logistic regression at five 
spatial extents. We used presence-absence by family and nativity (rather than species richness by family and nativity) as our dependent and independent variables because species richness by family and nativity was typically low. The probability of non-native fish family occurrence $[p(x)]$ from the logistic regression model equals $\mathrm{e}^{(\alpha+\beta x)} /\left(1+\mathrm{e}^{(\alpha+}\right.$ $\left.{ }^{\beta x}\right)$, where $\alpha$ is the intercept, $\beta$ is the effect of the independent variable on the dependent variable, and $\mathrm{x}$ is the independent variable (Agresti 2002). Values of $\beta<0$ indicate that $p(x)$ decreases as $x$ increases, while values of $\beta>0$ indicate that $p(x)$ increases as $x$ increases. Therefore, values of $\beta>0$ would be consistent with the Human Activity Hypothesis for all variables except for the disturbance indices (where values of $\beta<0$ would be consistent with the hypothesis). However, values of $\beta>0$ for disturbance metrics and $\beta<0$ for all other metrics may be consistent with the Human Activity Hypothesis for species intentionally introduced to remote areas (e.g., Adams et al. 2001; Pister 2001). For biotic independent variables (e.g., native species richness), values of $\beta<$ 0 suggest biotic resistance, and $\beta>0$ suggest biotic acceptance. We conducted our analyses at a "global" (i.e., the CRB and MRB combined) spatial extent, and by physiographic division ( $\mathrm{n}=4$; Fenneman and Johnson 1946; Figure 4.1) to account for the potential effects of large-scale natural environmental factors (e.g., elevation and geology) on the occurrence of fish species that may obscure the drivers of species invasions at large spatial scales.

We evaluated Biotic Resistance, Biotic Acceptance, and Human Activity hypotheses for non-native Salmonidae, Cyprinidae, and Catostomidae. We limited our analysis to these families because they commonly occurred in both basins and have native and non-native representatives in both basins, which was necessary because we 
used the presence-absence of native confamilials as metrics representing Biotic Resistance and Biotic Acceptance hypotheses. We also used native species richness to represent Biotic Resistance and Biotic Acceptance hypotheses for all three families, and the presence-absence of native Salmonidae as a metric of Biotic Resistance through predation for non-native Cyprinidae and Catostomidae. We used network crop land use, network human population density, local dam density, network dam density, and cumulative disturbance index as metrics of Human Activity for all families and spatial extents. All of these metrics directly represent potential habitat alteration, while local and network dam density may also directly represent propagule pressure. Furthermore, a negative relationship between non-native species and human activities may represent propagule pressure for non-native species stocked in remote areas (e.g., Adams et al. 2001; Pister 2001). In addition to Biotic Resistance, Biotic Acceptance, and Human Activity hypotheses, we evaluated physiographic division at the global spatial extent to serve as an ecologically relevant null model that accounted for natural environmental variability (e.g., precipitation, latitude, temperature and flow regimes) that may affect fish distributions and abundances across the large study area (Meador et al. 2003; Frimpong and Angermeier 2010a), and a statistical null model at all spatial extents to serve as a baseline for model comparisons.

We compared single-independent variable logistic regression models using Akaike's Information Criterion (AIC) because we were interested in identifying the single best predictor of non-native fish occurrence. The model with the lowest AIC value represented the most-supported model given the data and the models evaluated. Models were ranked according to their $\Delta \mathrm{AIC}$ values (i.e., $\Delta \mathrm{AIC}_{[\mathrm{i}]}=\mathrm{AIC}$ [of model "i"] - AIC [of 
most-supported model]). Models with a $\Delta \mathrm{AIC}<2$ are considered to receive substantial empirical support, while models with $\triangle \mathrm{AIC}$ between 4 and 7 receive considerably less support, and models with $\triangle \mathrm{AIC}>10$ have little empirical support (Burnham and Anderson 2002).

We assessed the goodness-of-fit of each model using pseudo- $R^{2}$ [McFadden 1974; Agresti 2002; also known as the likelihood ratio $R^{2}$ (Menard 2000)], calculated as $\left(\mathrm{L}_{0}-\right.$ $\left.\mathrm{L}_{\mathrm{m}}\right) / \mathrm{L}_{0}$, where $\mathrm{L}_{0}$ is the log-likelihood of the null model and the $\mathrm{L}_{\mathrm{m}}$ is the log-likelihood of the model evaluated. This measure is a useful measure for comparing models because it describes the improvement in fit (i.e., reduction in error) relative to the null model and, thus, has similar interpretation as the coefficient of determination in ordinary least squares regression, and is independent of the number of positive outcomes (i.e., nonnative family presence; Menard 2000). Models with pseudo- $R^{2}$ values between 0.2 and 0.4 are considered to have good fit (McFadden 1979; Hu and Lo 2007), so we only graphically displayed the effect of the independent variable on the dependent variable (i.e., probability of occurrence) for models with a pseudo- $R^{2}$ value $\geq 0.2$.

\section{Results}

Fish were collected at 6,619 stream segments: 1,589 in the Intermontane Plateaus physiographic division of the CRB, 369 in the Interior Highlands of the MRB, 2,209 in the Interior Plains of the MRB, and 2,452 in the Rocky Mountain System of the CRB $(\mathrm{n}=1,241)$ and $\operatorname{MRB}(\mathrm{n}=1,211)$. Non-native Salmonidae occurred at 1 segment in the Interior Highlands ( $0.3 \%$ of sampled segments), 160 segments $(7.2 \%)$ in the Interior Plains, 570 segments (35.9\%) in the Intermontane Plateaus, and 1,634 segments $(66.6 \%$; $\mathrm{n}=827$ in CRB and 807 in MRB) in the Rocky Mountain System physiographic division. 
Non-native Cyprinidae occurred at 97 segments (26.3\%) in the Interior Highlands, 580 (26.3\%) segments in the Interior Plains, 314 segments (19.8\%) in the Intermontane Plateaus, and 197 segments $(8.0 \% ; \mathrm{n}=185$ in CRB and 12 in MRB) in the Rocky Mountain System physiographic division. Non-native Catostomidae occurred at 4 segments (1.1\%) in the Interior Highlands, 21 segments (1.0\%) in the Interior Plains, 66 segments (4.2\%) in the Intermontane Plateaus, and 177 segments $(7.2 \% ; \mathrm{n}=177$ in CRB and 0 in MRB) in the Rocky Mountain System physiographic division.

Local scale metrics of human activity were strongly correlated $\left(p<0.0001 ; r_{s} \geq\right.$ $|0.6|$ ) to their network and cumulative (for disturbance index) scale counterparts for crop land use, human population density, and disturbance index (Table 4.1). Dam density was correlated to dam storage density at both spatial scales. Urban land use was strongly correlated to population density and crop land use at both spatial scales. Finally, local and network disturbance indices were strongly correlated to the cumulative disturbance index. Therefore, we retained local catchment dam density, network crop land use, network population density, network dam density, and cumulative disturbance index as metrics of human activity for our analyses.

The Biotic Resistance, Biotic Acceptance, and Human Activity hypotheses received little support as drivers of non-native Salmonidae presence across spatial extents. At the global spatial extent, the best predictor of non-native Salmonidae presence was physiographic division (pseudo- $R^{2}=0.26$; Table 4.2; Figure 4.2). Biotic Resistance, Biotic Acceptance, and Human Activity hypotheses did not receive meaningful support $(\triangle \mathrm{AIC}>629)$. The most-supported model (network population density) of non-native Salmonidae presence in the Intermontane Plateaus physiographic division of the CRB 
represented the Human Activity Hypothesis, and the estimate of $\beta(-0.027 ; \mathrm{SE}=0.012)$ indicated that the probability of non-native Salmonidae presence decreased with increased population density. The Biotic Acceptance Hypothesis (native Salmonidae) also received meaningful support $(\triangle \mathrm{AIC}=5.4 ; \beta=0.46 ; \mathrm{SE}=0.13)$, but none of the models for the Intermontane Plateaus explained meaningful variability in non-native Salmonidae presence (pseudo- $R^{2} \leq 0.01$ ). The only supported model for the Interior Plains physiographic division in the MRB represented the Human Activity Hypothesis and indicated the probability of non-native Salmonidae presence decreased with increased network crop land use ( $\beta=-0.052 ; \mathrm{SE}=0.0063)$, but the model did not explain substantial variability (pseudo- $R^{2}=0.11$; Table 4.2). The Biotic Resistance Hypothesis (native Salmonidae) was the only model to receive meaningful support in the Rocky Mountain System (CRB and MRB) and indicated the probability non-native Salmonidae occurrence was lower where native Salmonidae occurred ( $\beta=-1.47$; $\mathrm{SE}=0.095$; Table 4.2), but this model did not explain significant variability in non-native Salmonidae presence (pseudo$\left.R^{2}=0.08\right)$. The drivers of non-native Salmonidae presence were not evaluated for the Interior Highlands physiographic division of the MRB due to a lack of occurrences $(\mathrm{n}=1$ of 369 segments).

Biotic Resistance and Biotic Acceptance hypotheses were the most-supported models of non-native Cyprinidae presence across spatial extents, but the most-supported variables differed among regions and generally explained little variability in non-native Cyprinidae presence. The Biotic Acceptance Hypothesis was supported at the global extent, as the probability of non-native Cyprinidae presence increased with native Cyprinidae presence (pseudo- $R^{2}=0.10 ; \beta=1.92 ; \mathrm{SE}=0.089$; Table 4.3). The other models 
did not receive meaningful support ( $\triangle \mathrm{AIC}>200$ ). The Biotic Acceptance Hypothesis was the most-supported model in both the Interior Highlands and Interior Plains physiographic divisions of the MRB because the probability of non-native Cyprinidae presence increased with native species richness (Interior Highlands: $\beta=0.12, \mathrm{SE}=0.020$; Interior Plains: $\beta=0.11, \mathrm{SE}=0.0087$ ), but neither model had good fit (pseudo- $R^{2} \leq 0.10$; Table 4.3). No other variables received meaningful support for either region $(\Delta \mathrm{AIC}>36$; Table 4.3). The Biotic Acceptance Hypothesis was also supported in the Rocky Mountain System of the MRB and CRB because the probability of the non-native Cyprinidae presence was higher at stream segments where native Cyprinidae were also present ( $\beta=3.19 ; \mathrm{SE}=0.17$; pseudo- $R^{2}=0.28$; Table 4.3; Figure 4.2). No other variables received meaningful support for the Rocky Mountain System ( $\triangle \mathrm{AIC}>150$; Table 4.3). Finally, the Biotic Resistance Hypothesis was supported for the Intermontane Plateaus of the $\mathrm{CRB}$, as the probability of non-native Cyprinidae presence decreased when native Salmonidae were present $\left(\beta=-1.95 ; \mathrm{SE}=0.30\right.$; pseudo- $R^{2}=0.04$; Table 4.3$)$, and other variables did not receive meaningful support $(\Delta \mathrm{AIC}>33$; Table 4.3).

The drivers on non-native Catostomidae presence varied among spatial extents. The Human Activity Hypothesis (network crop land use) was the most-supported model at the global extent, but did not explain significant variability (pseudo- $R^{2}=0.03$; Table 4.4). For the Intermontane Plateaus physiographic division of the CRB, the Human Activity (cumulative disturbance index) and Biotic Acceptance (native species richness) hypotheses resulted in the two most-supported models (i.e., non-native Catostomidae presence increased with cumulative disturbance index in the most-supported model and increased with native species richness in the second-most supported model), but neither 
model had good model fit (pseudo- $R^{2} \leq 0.07$; Table 4.4). In the Interior Plains of the MRB, the Biotic Acceptance Hypothesis was the only model that received meaningful support and had good model fit (pseudo- $R^{2}=0.35$ ), as the probability of non-native Catostomidae presence increased with native species richness $(\beta=0.28 ; \mathrm{SE}=0.034$; Table 4.4; Figure 4.2). The Biotic Acceptance Hypothesis was the only supported model in the Rocky Mountain System (CRB and MRB), as the probability of non-native Catostomidae presence increased when native Catostomidae were present $(\beta=2.07$; $\mathrm{SE}=0.16$; pseudo$R^{2}=0.11$; Table 4.4). The drivers of non-native Catostomidae presence were not evaluated for the Interior Highlands due to the lack of occurrences ( $n=4$ of 369 segments).

\section{Discussion}

The drivers of non-native fish invasions varied within and among families and spatial extents, but no obvious patterns across families and extents were present. The best predictor of non-native Salmonidae varied among spatial extents: physiographic division at the global extent, metrics of human activity (potentially representing stocking into remote areas; Adams et al. 2001; Pister et al. 2001) in two physiographic divisions, and Biotic Resistance in one physiographic division. Similarly, the drivers of non-native Cyprinidae varied among extents with support for the Biotic Resistance Hypothesis in

one physiographic division and the Biotic Acceptance Hypothesis at the global extent and for three physiographic divisions, but the most-supported metrics of Biotic Acceptance varied among regions. Non-native Catostomidae supported the Human Activity Hypothesis at two extents and the Biotic Acceptance Hypothesis at two extents. Finally, the drivers of non-native lotic fishes generally differed among families within each spatial extent, with an exception being support of the Biotic Acceptance Hypothesis for 
non-native Cyprinidae and Catostomidae in two physiographic divisions. Our finding of different drivers of non-native species among families was consistent with Whitney et al. (2017), who found that some non-native families were associated with human activity (i.e., dams), whereas other families were associated with natural abiotic factors (e.g., climate). Similarly, our conclusion of different drivers of non-native species among spatial extents is consistent with Blanchet et al. (2009) who found that the drivers of nonnative species richness at the river basin spatial grain differed between their analyses at worldwide and biogeographic region spatial extents. Specifically, these authors found support for the Human Activity Hypothesis at the worldwide extent and the Human Activity and Biotic Acceptance hypotheses when analyses were conducted by biogeographic region.

Spatial grain size of analysis may affect the perceived drivers of species invasions, with more support for Biotic Resistance and Biotic Acceptance hypotheses at smaller spatial grains than at larger spatial grains. At a small spatial grain (i.e., stream segment), we found that metrics representing the Biotic Acceptance Hypothesis were the most-supported variables for 6 of the 13 model sets evaluated and resulted in the only two models representing the hypothesized drivers (excluding physiographic division for non-native Salmonidae) that had good model fit (i.e., pseudo- $R^{2} \geq 0.2$ ). Meanwhile, the Human Activity Hypothesis was the most-supported hypothesis in four model sets and the Biotic Resistance Hypothesis was the most-supported models in two model sets. Similarly, other studies at small spatial grains (e.g., stream reaches) have provided support for Human Activity (Meador et al. 2003; Gido et al. 2004; Hermoso et al. 2011), Biotic Acceptance (dos Santos et al. 2018), and Biotic Resistance hypotheses (Fitzgerald 
et al. 2016). Unlike these studies at small spatial grains, studies at larger spatial grain sizes (e.g., river basin) almost exclusively provided support for the Human Activity Hypothesis (Gido et al. 2004; Light and Marchetti 2007; Leprieur et al. 2008; Blanchet et al. 2009; Copp et al. 2010; Lapointe and Light 2012; Pool et al. 2010), although Blanchet et al. (2009) provided support for the Biotic Acceptance Hypothesis in some regions. The greater support for biotic interactions structuring fish assemblages at small spatial grains than at large spatial grains is consistent with Tonn (1990), Poff (1997), Jackson et al. (2001), and Fitzgerald et al. (2016), who suggested that biotic interactions are more likely to structure fish assemblages at small scales (i.e., grain) than at larger spatial scales.

Natural environmental factors (e.g., climate, geology, and in-stream habitat) may be more important drivers of non-native fish occurrence at the stream segment spatial grain than metrics human activity or interactions with the native fish assemblage for the spatial extents evaluated in this study. Most model sets in our study (10 of 13 familyregion combinations) did not contain models with good fit (i.e., psuedo- $R^{2} \geq 0.2$ ), suggesting that human activities and the native fish assemblage may not be the primary drivers of non-native Salmonidae, Catostomidae, and Cyprinidae presence. Furthermore, one of the models with good fit (i.e., non-native Salmonidae global extent model set) indicated that natural environmental variability (i.e., physiographic division) was a better predictor of non-native Salmonidae occurrence than metrics of human activity or the native fish assemblage, but this result may also reflect variability in propagule pressure among physiographic divisions (e.g., more non-native trout stockings in the Rocky Mountain System relative to other regions). The hypothesis that natural environmental factors are primary drivers of species invasions at this spatial scale is consistent with 
Pierce (2019; Chapter 3; MRB and CRB) and Whitney et al. (2017; upper CRB), who found that natural environmental factors were often important predictors of non-native species occurrences, though non-native Cyprinidae and families not evaluated in this study were also associated with dams in the upper CRB (Whitney et al. 2017).

Furthermore, natural factors (e.g., watershed area, climatic factors, and hydrological regime) were identified as important predictors of non-native species invasion success (Moyle and Light 1996), density (Propst et al. 2008), richness (Gido and Brown 1999; Gido et al. 2004; Light and Marchetti 2007; Blanchet et al. 2009), functional diversity (Pool et al. 2010), and species composition (Pool et al. 2010; Lapointe and Light 2012) at multiple spatial grains.

Considering non-native species invasions within the context of hierarchical habitat filters (Tonn 1990; Poff 1997; Jackson et al. 2001) may provide clarity on the context-dependent nature (Blanchet et al. 2009; e.g., vary by species, spatial extent, and spatial grain) of the drivers of species invasions. From the hierarchical habitat filtering perspective, non-native species establishment can be viewed as a stepwise process: 1) species introduced to new area, bypassing biogeographical filters; 2) environmental filters determine potential distribution within introduced range; and 3) biotic interactions determine realized distribution within potential distribution. Therefore, in order for mechanisms to drive non-native species establishment at steps 2 or 3 , the preceding step(s) may need to be satisfied. For example, it may be unwarranted to conclude that biotic interactions (e.g., Biotic Resistance Hypothesis) prevented the establishment of a non-native species that was not introduced or was introduced to an area without suitable abiotic conditions (e.g., thermal regime). This invasion process may explain variability in 
the drivers of invasion among spatial scales. The presence of a non-native species in a region is first dependent on human introductions (i.e., Step 1), suggesting the Human Activity Hypothesis should be supported at large spatial scales. Meanwhile, intermediate spatial scales may relate to Step 2 in the invasion process, with non-native species distributions dependent on natural (potentially supporting Biotic Acceptance Hypothesis as a surrogate for intermediate-scale habitat quality) or anthropogenic environmental factors (i.e., Human Activity Hypothesis). At the smallest spatial scales, the Biotic Acceptance (as a surrogate for fine-scale habitat quality) or Biotic Resistance (i.e., negative species interactions) hypotheses may explain non-native species occurrence. Finally, the proposed hierarchical habitat filtering process highlights the need to evaluate the drivers of species invasions at the species taxonomic level because the means (e.g., stocking or unintentional) and spatial extent of introductions (i.e., Step 1), environmental needs (i.e., Step 2), and potential biotic interactions (i.e., Step 3) likely vary among species.

\section{References}

Adams, S. B., C. A. Frissell, and B. E. Rieman. 2001. Geography of invasion in mountain streams: Consequences of headwater lake fish introductions. Ecosystems 4:296307.

Agresti, A. 2002. Categorical data analysis, $2^{\text {nd }}$ edition. John Wiley \& Sons: Hoboken, NJ.

Annis, G. M., S. P. Sowa, D. D. Diamond, A. Garringer, P. Hanberry, and M. E. Morey. 2010. A GAP Analysis for riverine ecosystems of the Missouri River basin final report. U.S. Geological Survey, Gap Analysis Program, Reston, VA. 
Blanchet, S., F. Leprieur, O. Beauchard, J. Staes, T. Oberdorff, and S. Brosse. 2009. Broad-scale determinants of non-native fish species richness are contextdependent. Proceedings of the Royal Society B 276:2385-2394.

Blinn, D. W., and N. L. Poff. 2005. Colorado River basin. Pages 483-538 in A. Benke and C.E. Cushing, editors. Rivers of North America. Elsevier, Oxford.

Burnham, K. P., and D. R. Anderson. 2002. Model selection and multimodel inference: A practical information-theoretic approach, 2nd edition. Springer, New York.

Carlson, C. A., and R. T. Muth 1989. The Colorado River: Lifeline of the American Southwest. Canadian Special Publication of Fisheries and Aquatic Sciences 106: $220-239$.

Copp, G. H., L. Vilizzi., and R. E. Gozlan. 2010. The demography of introduction pathways, propagule pressure and occurrences of non-native freshwater fish in England. Aquatic Conservation: Marine and Freshwater Ecosystems 20:595-601.

Cross, F. B., R. L. Mayden, and J. D. Stewart. 1986. Fishes of the western Mississippi drainage. Pages 363-412 in C. H. Hocutt and E. O. Wiley, editors. The zoogeography of North American freshwater fishes. Wiley, New York.

Dos Santos, D. A., D. J. Hoeinghaus, and L. C. Gomes. 2018. Spatial scales and the invasion paradox: A test using fish assemblages in a Neotropical floodplain. Hydrobiologia 817:121-131.

ESRI (Environmental System Research Institute). 2009. ArcGIS version 9.3. Environmental System Research Institute, Redlands, CA.

Esselman, P. C., D. M. Infante, L. Wang, W. W. Taylor, W. M. Daniel, R. Tingley, J. Fenner, A. Cooper, D. Wieferich, D. Thornbrugh, and J. Ross. 2011a. National 
Fish Habitat Action Plan (NFHAP) 2010 HCI scores and human disturbance data for conterminous United States linked to NHDPLUSV1. United States Geological Survey - National Fish Habitat Partnership. Available at http://dx.doi.org/doi:10.5066/F7B56GN1. Accessed 8/19/2013.

Esselman, P. C., D. M. Infante, L. Wang, D. Wu, A. R. Cooper, and W. M. Taylor. 2011b. An index of cumulative disturbance to river fish habitats of the conterminous United States from landscape anthropogenic activities. Ecological Restoration 29:133-151.

Fenneman, N. M., and D. W. Johnson. 1946. Physiographic divisions of the conterminous U.S. U.S. Geological Survey, Reston, VA. Available at https://water.usgs.gov/GIS/dsdl/physio_shp.zip. Accessed 4/1/2017.

Fitzgerald, D. B., M. Tobler, and K. O. Winemiller. 2016. From richer to poorer: Successful invasion by freshwater fishes depends on species richness of donor and recipient basins. Global Change Biology 22:2440-2450.

Fridley, J. D., J. J. Stachowicz, S. Naeem, D. F. Sax, E. W. Seabloom, M. D. Smith, T. J. Stohlgren, D. Tilman, and B. Von Holle. 2007. The invasion paradox: Reconciling pattern and process in species invasions. Ecology 88:3-17.

Frimpong, E. A., and P. L. Angermeier. 2010a. Comparative utility of selected frameworks for regionalizing fish-based bioassessments across the United States. Transactions of the American Fisheries Society 139:1872-1895.

Frimpong, E. A., and P. L. Angermeier. 2010b. Trait-based approaches in the analysis of stream fish communities. Pages 109-136 in K. B. Gido and D. A. Jackson, editors. 
Community ecology of stream fishes: concepts, approaches, and techniques. American Fisheries Society, Symposium 73, Bethesda, MD.

Galat, D. L. C. R. Berry, W. M. Gardner, J. C. Hendrickson, G. E. Mestl, G. J. Power, C. Stone, and M. R. Winston. 2005a. Spatiotemporal patterns and changes in Missouri River fishes. Pages 249-291 in J. Rinne, R. M. Hughes, and B. Calamusso, editors. Historical changes in large river fish assemblages of the Americas. American Fisheries Society Symposium 45, Bethesda, MD.

Galat, D. L., C. R. Berry Jr., E. J. Peters, and R. G. White. 2005b. Missouri River basin. Pages 427-480 in A. C. Benke and C. E. Cushing, editors. Rivers of North America. Elsevier, Oxford.

Gido, K. B., and J. H. Brown. 1999. Invasion of North American drainages by alien fish species. Freshwater Biology 42: 387-399.

Gido, K. B., J. F. Schaefer, J. Pigg. 2004. Patterns of fish invasions in the Great Plains of North America. Biological Conservation 118:121-131.

Hermoso, V., M. Clavero, F. Blanco-Garrido, and J. Prenda. 2011. Invasive species and habitat degradation in Iberian streams: An analysis of their role in freshwater fish diversity loss. Ecological Applications 21:175-188.

Hu, Z., and C. P. Lo. 2007. Modeling urban growth in Atlanta using logistic regression. Computers, Environment and Urban Systems 31:667-688.

Jackson, D. A., P. R. Peres-Neto, and J. D. Olden. 2001. What controls who is where in freshwater fish communities- the roles of biotic, abiotic, and spatial factors. Canadian Journal of Fisheries and Aquatic Sciences 58:157-170. 
Kolar, C. S., and D. M. Lodge. 2001. Progress in invasion biology: Predicting invaders. Trends in Ecology and Evolution 16:199-204.

Kolar, C. S., and D. M. Lodge. 2002. Ecological predictions and risk assessment for alien fishes in North America. Science 298:1233-1236.

Kominoski, J. S., A. Ruhí, M. M. Hagler, K. Petersen, J. L. Sabo, T. Sinha, A. Sankarasubramanian, and J. D. Olden. 2018. Patterns and drivers of fish extirpations in rivers of the American Southwest and Southeast. Global Change Biology 24:1175-1185.

Lapointe, N. W. R., and T. Light. 2012. Landscape-scale determinants of non-native fish communities. Biodiversity Research 18:282-293.

Leprieur, F., O. Beauchard, S. Blanchet, T. Oberdorff, and S. Brosse. 2008. Fish invasions of the world's river systems: When natural process are blurred by human activities. PLoS Biology 6:404-410.

Levine, J. M., and C. M. D'Antonio. 1999. Elton revisited: A review of evidence linking diversity and invasibility. Oikos 87:15-26.

Light, T., and M. P. Marchetti. 2007. Distinguishing between invasions and habitat changes as drivers of diversity loss among California's freshwater fishes. Conservation Biology 21:434-446.

Malmqvist, B., and S. Rundle. 2002. Threats to running water ecosystems of the world. Environmental Conservation 29:134-153.

Marchetti, M. P., T. Light, P. B. Moyle, and J. H. Viers. 2004. Fish invasions in California watersheds: Testing hypotheses using landscape patterns. Ecological Applications 14:1507-1525. 
McFadden, D. 1974. Conditional logit analysis of qualitative choice behavior. Pages 105142 in P. Zarembka, editor. Frontiers in econometrics. Academic Press: New York.

McFadden, D. 1979. Quantitative methods for analyzing travel behavior of individuals: Some recent developments. Pages 279-318 in D. A. Hensher and P. R. Stopher, editors. Behavioural travel modelling. Croom Helm: London.

McKay, L., T. Bondelid, T. Dewald, J. Johnston, R. Moore, and A Rea. 2012. NHDPlus version 2: User guide. Available at ftp://ftp.horizon-systems.com/NHDplus/ NHDPlusV21/Documentation/NHDPlusV2_User_Guide.pdf. Accessed $1 / 28 / 2019$.

Meador, M. R., L. R. Brown, and T. Short. 2003. Relations between introduced fish and environmental conditions at large geographic scales. Ecological Indicators 3:8192.

Menard, S. 2000. Coefficients of determination for multiple logistic regression analysis. The American Statistician 54:17-24.

Miller, R. R., J. D., Williams, and J. E. Williams. 1989. Extinctions of North American fishes during the past century. Fisheries 14:22-38.

Minckley W. L, and J. E. Deacon. 1991. Battle against extinction: Native fish management in the American west. University of Arizona Press, Tucson, AZ.

Minckley, W. L., D. A. Henderson, and C. E. Bond. 1986. Geography of western North American freshwater fishes: Description and relationships to intercontinental tectonism. Pages 519-613 in C. H. Hocutt and E. O. Wiley, editors. The zoogeography of North American freshwater fishes. Wiley, New York. 
Mitchell, A. L., and H. H. Knouft. 2009. Non-native fishes and native species diversity in freshwater fish assemblages across the United States. Biological Invasions 11:1441-1450.

Moyle, P. B., and T. Light. 1996. Fish invasions in California: Do abiotic factors determine success?. Ecology 77:1666-1670.

Mueller, G. A., P. C. Marsh, and W. L. Minckley. 2005. A legacy of change: The lower Colorado River, Arizona-California-Nevada, USA and Sonora-Baja California Norte, Mexico. Pages 139-156 in J. Rinne, R. M. Hughes, and B. Calamusso, editors. Historical changes in large river fish assemblages of the Americas. American Fisheries Society Symposium 45, Bethesda, MD.

Olden, J. D., M. K. Kennard, F. Leprieur, P. A. Tedesco, K. O. Winemiller, and E. García-Berthou. 2010. Conservation biogeography of freshwater fishes: Past progress and future directions. Diversity and Distributions 16: 496-513.

Olden, J. D., N. L. Poff, and K. B. Bestgen. 2006. Life-history strategies predict fish invasions and extirpations in the Colorado River basin. Ecological Monographs 73:25-40.

Pierce, L. L. 2019. Conservation biogeography of lotic fishes in the Missouri and Colorado River basins. Doctoral dissertation. University of Missouri, Columbia. Pister, E. P. 2001. Wilderness fish stocking: History and perspective. Ecosystems 4:279286.

Poff, N. L. 1997. Landscape filters and species traits: Towards mechanistic understanding and prediction in stream ecology. Journal of the North American Benthological Society 16:391-409. 
Pool, T. K., J. D. Olden, J. B. Whittier, and C. P. Paukert. 2010. Environmental drivers of fish functional diversity and composition in the lower Colorado River basin. Canadian Journal of Fisheries and Aquatic Sciences 67:1791-1807.

Propst, D. L., K. B. Gido, and J. A. Stefferud. 2008. Natural flow regimes, non-native fishes, and native fish persistence in arid-land river systems. Ecological Applications 18:1236-1252.

Ruesink, J. L. 2005. Global analysis of factors affecting the outcome of freshwater fish introductions. Conservation Biology 19:1883-1893.

Tonn, W. M. 1990. Climate change and fish communities: A conceptual framework. Transactions of the American Fisheries Society 119:337-352.

Tyus, H. M., B. D. Burdick, R. A. Valdez, C. M. Haynes, T. A. Lytle, and C. R. Berry. 1982. Fishes of the upper Colorado River basin: Distribution, abundance and status. Pages 12-70 in W. H. Miller, H. M. Tyus, and C. A. Carslon, editors. Fishes of the upper Colorado River system: present and future. Western Division, American Fisheries Society, Bethesda, MD.

Tyus, H. M., and J. F. Saunders III. 2000. Nonnative fish control and endangered fish recovery: Lessons from the Colorado River. Fisheries 25:17-24.

USACE (U.S. Army Corps of Engineers). 2010. National inventory of dams. Washington, D.C.

USEPA (U.S. Environmental Protection Agency). 2005. National Hydrography Dataset Plus - NHDPlus- Strahler order. Available at http://www.horizonsystems.com/nhdplus/strahlerlist.php. Accessed 4/1/2017. 
USEPA (U.S. Environmental Protection Agency) and USGS (U.S. Geological Survey). 2005. National hydrography dataset plus - NHDPlus. Available at http://www.horizon-systems.com/NHDPlus/NHDPlusV1_data.php. Accessed $6 / 28 / 2013$

Valdez, R. A., and R. M. Muth. 2005. Ecology and conservation of native fishes in the upper Colorado River basin. Pages 157-205 in J. Rinne, R.M. Hughes, and B. Calamusso, editors. Historical changes in large river fish assemblages of the Americas. American Fisheries Society Symposium 45, Bethesda, MD.

Whitney, J. E., J. B. Whittier, and C. P. Paukert. 2017. Environmental niche models for riverine desert fishes and their similarity according to phylogeny and functionality. Ecosphere 8:e01658.

Whittier, J. B., C. P. Paukert, J. D. Olden, K. L. Pitts, and A. L. Strecker. 2011. Lower Colorado River Basin aquatic gap analysis project: Final report. U.S. Geological Survey, Gap Analysis Program, Reston, VA.

Whittier, J. B., and N. Sievert. 2014. Conservation assessment for native fish in the Upper Colorado River Basin. Final report to the Western Native Trout Initiative and National Fish Habitat Partnership, Lakewood, CO.

Wittenberg, R., and M. J. W. Cock, editors. 2001. Invasive alien species: A toolkit of best prevention and management practices. CAB International, Wallingford, Oxon, United Kingdom. 


\section{Tables}

Table 4.1. Spearman rank correlation $\left(r_{s}\right)$ of landscape-level metrics of human activity for 1 st to 4th order stream segments in the Missouri and Colorado River basins where fish were collected for this study. The top value represents $r_{s}$ and the bottom value represents the $p$-value for each correlation. Values in bold indicate strong $\left(r_{s} \geq|0.6|\right)$ correlations. Prefixes "L_", "N_", and "C_" represent local catchment, network watershed, and cumulative spatial scales, respectively, of landscape-level environmental data.

\begin{tabular}{|c|c|c|c|c|c|c|c|c|c|c|c|c|}
\hline & $\begin{array}{c}\text { L_Population } \\
\text { density }\end{array}$ & $\begin{array}{l}\text { N_Crop } \\
\text { land use }\end{array}$ & $\begin{array}{c}\text { N_Population } \\
\text { density }\end{array}$ & $\begin{array}{c}\text { L_Disturbance } \\
\text { index }\end{array}$ & $\begin{array}{c}\text { N_Disturbance } \\
\text { index }\end{array}$ & $\begin{array}{c}\text { C_Disturbance } \\
\text { index }\end{array}$ & $\begin{array}{l}\text { L_Dam } \\
\text { density }\end{array}$ & $\begin{array}{l}\text { N_Dam } \\
\text { density }\end{array}$ & $\begin{array}{l}\text { L_Dam } \\
\text { storage } \\
\text { density }\end{array}$ & $\begin{array}{l}\text { N_Dam } \\
\text { storage } \\
\text { density }\end{array}$ & $\begin{array}{l}\text { L_Urban } \\
\text { land use }\end{array}$ & $\begin{array}{l}\text { N_Urban } \\
\text { land use }\end{array}$ \\
\hline L_Crop land & 0.463 & 0.859 & 0.473 & -0.491 & -0.497 & -0.500 & 0.177 & 0.375 & 0.176 & 0.327 & 0.612 & 0.661 \\
\hline use & $<0.0001$ & $<0.0001$ & $<0.0001$ & $<0.0001$ & $<0.0001$ & $<0.0001$ & $<0.0001$ & $<0.0001$ & $<0.0001$ & $<0.0001$ & $<0.0001$ & $<0.0001$ \\
\hline L_Population & & 0.462 & 0.908 & -0.558 & -0.523 & -0.520 & 0.144 & 0.297 & 0.144 & 0.289 & 0.627 & 0.633 \\
\hline density & & $<0.0001$ & $<0.0001$ & $<0.0001$ & $<0.0001$ & $<0.0001$ & $<0.0001$ & $<0.0001$ & $<0.0001$ & $<0.0001$ & $<0.0001$ & $<0.0001$ \\
\hline N_Crop land & & & 0.501 & -0.509 & -0.574 & -0.566 & 0.173 & 0.449 & 0.172 & 0.401 & 0.632 & 0.729 \\
\hline use & & & $<0.0001$ & $<0.0001$ & $<0.0001$ & $<0.0001$ & $<0.0001$ & $<0.0001$ & $<0.0001$ & $<0.0001$ & $<0.0001$ & $<0.0001$ \\
\hline N_Population & & & & -0.521 & -0.572 & -0.538 & 0.140 & 0.336 & 0.140 & 0.322 & 0.601 & 0.695 \\
\hline density & & & & $<0.0001$ & $<0.0001$ & $<0.0001$ & $<0.0001$ & $<0.0001$ & $<0.0001$ & $<0.0001$ & $<0.0001$ & $<0.0001$ \\
\hline L_Disturbance & & & & & 0.657 & 0.799 & -0.156 & -0.313 & -0.156 & -0.306 & -0.627 & -0.581 \\
\hline index & & & & & $<0.0001$ & $<0.0001$ & $<0.0001$ & $<0.0001$ & $<0.0001$ & $<0.0001$ & $<0.0001$ & $<0.0001$ \\
\hline N_Disturbance & & & & & & 0.925 & -0.243 & -0.598 & -0.243 & -0.568 & -0.562 & -0.670 \\
\hline index & & & & & & $<0.0001$ & $<0.0001$ & $<0.0001$ & $<0.0001$ & $<0.0001$ & $<0.0001$ & $<0.0001$ \\
\hline C_Disturbance & & & & & & & -0.237 & -0.570 & -0.237 & -0.544 & -0.580 & -0.637 \\
\hline index & & & & & & & $<0.0001$ & $<0.0001$ & $<0.0001$ & $<0.0001$ & $<0.0001$ & $<0.0001$ \\
\hline \multirow[t]{2}{*}{ L_Dam density } & & & & & & & & 0.329 & 1.000 & 0.293 & 0.150 & 0.167 \\
\hline & & & & & & & & $<0.0001$ & $<0.0001$ & $<0.0001$ & $<0.0001$ & $<0.0001$ \\
\hline \multirow[t]{2}{*}{ N_Dam density } & & & & & & & & & 0.329 & 0.966 & 0.372 & 0.454 \\
\hline & & & & & & & & & $<0.0001$ & $<0.0001$ & $<0.0001$ & $<0.0001$ \\
\hline L_Dam storage & & & & & & & & & & 0.293 & 0.150 & 0.166 \\
\hline density & & & & & & & & & & $<0.0001$ & $<0.0001$ & $<0.0001$ \\
\hline N_Dam storage & & & & & & & & & & & 0.354 & 0.429 \\
\hline density & & & & & & & & & & & $<0.0001$ & $<0.0001$ \\
\hline L_Urban land & & & & & & & & & & & & 0.817 \\
\hline use & & & & & & & & & & & & $<0.0001$ \\
\hline
\end{tabular}


Table 4.2. Logistic regression model results for Human Activity, Biotic Resistance, and Biotic Acceptance hypotheses predicting nonnative Salmonidae presence in the Missouri and Colorado River basins. Interior Highlands was excluded from analysis by physiographic division due to low sample size. $\mathrm{k}=$ number of model parameters.

\begin{tabular}{|c|c|c|c|c|c|c|c|}
\hline Spatial Extent & Variable & Hypothesis & $\mathrm{AIC}$ & $\triangle \mathrm{AIC}$ & $\mathrm{k}$ & Deviance & $\begin{array}{c}\text { Pseudo- } \\
R^{2} \\
\end{array}$ \\
\hline \multirow[t]{9}{*}{ Global } & Physiographic division & Natural & 6366.6 & 0.0 & 4 & 6358.6 & 0.26 \\
\hline & Native species richness & Biotic Acceptance/ Resistance & 6996.1 & 629.5 & 2 & 6992.1 & 0.19 \\
\hline & Network crop land use & Human Activity & 7348.4 & 981.8 & 2 & 7344.4 & 0.15 \\
\hline & Network population density & Human Activity & 8210.6 & 1844.0 & 2 & 8206.6 & 0.05 \\
\hline & Cumulative disturbance & Human Activity & 8317.3 & 1950.7 & 2 & 8313.3 & 0.04 \\
\hline & Native Salmonidae & Biotic Acceptance/ Resistance & 8425.5 & 2058.9 & 2 & 8421.5 & 0.02 \\
\hline & Network dam density & Human Activity & 8486.5 & 2119.9 & 2 & 8482.5 & 0.02 \\
\hline & Local catchment dam density & Human Activity & 8616.7 & 2250.1 & 2 & 8612.7 & 0.00 \\
\hline & Null & & 8631.2 & 2264.6 & 1 & 8629.2 & 0.00 \\
\hline
\end{tabular}

$\underset{\perp}{\omega}$ Interior Highlands $\quad$ N/A

$\begin{array}{llllllll}\text { Intermontane } & \text { Network population density } & \text { Human Activity } & 2060.7 & 0.0 & 2 & 2056.7 & 0.01 \\ \text { Plateaus } & \text { Native Salmonidae } & \text { Biotic Acceptance/ Resistance } & 2066.1 & 5.4 & 2 & 2062.1 & 0.01 \\ & \text { Cumulative disturbance } & \text { Human Activity } & 2067.1 & 6.4 & 2 & 2063.1 & 0.01 \\ & \text { Network dam density } & \text { Human Activity } & 2068.2 & 7.5 & 2 & 2064.2 & 0.00 \\ & \text { Null } & & 2076.2 & 15.5 & 1 & 2074.2 & 0.00 \\ & \text { Network crop land use } & \text { Human Activity } & 2078.1 & 17.4 & 2 & 2074.1 & 0.00 \\ & \text { Local catchment dam density } & \text { Human Activity } & 2078.2 & 17.5 & 2 & 2074.2 & 0.00 \\ & \text { Native species richness } & \text { Biotic Acceptance/ Resistance } & 2078.2 & 17.5 & 2 & 2074.2 & 0.00 \\ & & & & & & & \\ \text { Interior Plains } & \text { Network crop land use } & \text { Human Activity } & 1026.1 & 0.0 & 2 & 1022.1 & 0.11 \\ & \text { Network dam density } & \text { Human Activity } & 1061.2 & 35.1 & 2 & 1057.2 & 0.08 \\ & \text { Native Salmonidae } & \text { Biotic Acceptance/ Resistance } & 1066.9 & 40.8 & 2 & 1062.9 & 0.07 \\ & \text { Native species richness } & \text { Biotic Acceptance/ Resistance } & 1080.5 & 54.4 & 2 & 1076.5 & 0.06 \\ & \text { Cumulative disturbance } & \text { Human Activity } & 1089.0 & 62.9 & 2 & 1085.0 & 0.06 \\ & \text { Network population density } & \text { Human Activity } & 1097.3 & 71.2 & 2 & 1093.3 & 0.05\end{array}$




\begin{tabular}{|c|c|c|c|c|c|c|c|}
\hline Spatial Extent & Variable & Hypothesis & AIC & $\triangle \mathrm{AIC}$ & $\mathrm{k}$ & Deviance & $\begin{array}{c}\text { Pseudo- } \\
R^{2}\end{array}$ \\
\hline \multirow{10}{*}{$\begin{array}{l}\text { Rocky Mountain } \\
\text { System }\end{array}$} & Local catchment dam density & Human Activity & 1142.3 & 116.2 & 2 & 1138.3 & 0.01 \\
\hline & Null & & 1150.2 & 124.1 & 1 & 1148.2 & 0.00 \\
\hline & Native Salmonidae & Biotic Acceptance/ Resistance & 2862.4 & 0.0 & 2 & 2858.4 & 0.08 \\
\hline & Native species richness & Biotic Acceptance/ Resistance & 2992.7 & 130.3 & 2 & 2988.7 & 0.04 \\
\hline & Cumulative disturbance & Human Activity & 3106.1 & 243.7 & 2 & 3102.1 & 0.01 \\
\hline & Network population density & Human Activity & 3117.8 & 255.4 & 2 & 3113.8 & 0.00 \\
\hline & Null & & 3124.4 & 262.0 & 1 & 3122.4 & 0.00 \\
\hline & Network crop land use & Human Activity & 3125.1 & 262.7 & 2 & 3121.1 & 0.00 \\
\hline & Network dam density & Human Activity & 3125.6 & 263.2 & 2 & 3121.6 & 0.00 \\
\hline & Local catchment dam density & Human Activity & 3125.9 & 263.5 & 2 & 3121.9 & 0.00 \\
\hline
\end{tabular}


Table 4.3. Logistic regression model results for Human Activity, Biotic Resistance, and Biotic Acceptance hypotheses predicting nonnative Cyprinidae presence in the Missouri and Colorado River basins. $\mathrm{k}=$ number of model parameters.

\begin{tabular}{|c|c|c|c|c|c|c|c|}
\hline Spatial Extent & Variable & Hypothesis & $\mathrm{AIC}$ & $\triangle \mathrm{AIC}$ & $\mathrm{k}$ & Deviance & $\begin{array}{c}\text { Pseudo- } \\
R^{2} \\
\end{array}$ \\
\hline \multirow[t]{10}{*}{ Global } & Native Cyprinidae & Biotic Acceptance/ Resistance & 5597.4 & 0.0 & 2 & 5593.4 & 0.10 \\
\hline & Native species richness & Biotic Acceptance/ Resistance & 5806.3 & 208.9 & 2 & 5802.3 & 0.07 \\
\hline & Native Salmonidae & Biotic Acceptance/ Resistance & 5858.1 & 260.7 & 2 & 5854.1 & 0.06 \\
\hline & Physiographic division & Natural & 5927.5 & 330.1 & 4 & 5919.5 & 0.05 \\
\hline & Cumulative disturbance & Human Activity & 6027.1 & 429.7 & 2 & 6023.1 & 0.03 \\
\hline & Network crop land use & Human Activity & 6049.9 & 452.5 & 2 & 6045.9 & 0.03 \\
\hline & Network dam density & Human Activity & 6222.1 & 624.7 & 2 & 6218.1 & 0.00 \\
\hline & Local catchment dam density & Human Activity & 6230.5 & 633.1 & 2 & 6226.5 & 0.00 \\
\hline & Network population density & Human Activity & 6231.7 & 634.3 & 2 & 6227.7 & 0.00 \\
\hline & Null & & 6231.9 & 634.5 & 1 & 6229.9 & 0.00 \\
\hline \multirow[t]{9}{*}{ Interior Highlands } & Native species richness & Biotic Acceptance/ Resistance & 384.9 & 0.0 & 2 & 380.9 & 0.10 \\
\hline & Network crop land use & Human Activity & 421.1 & 36.1 & 2 & 417.1 & 0.02 \\
\hline & Native Cyprinidae & Biotic Acceptance/ Resistance & 423.6 & 38.6 & 2 & 419.6 & 0.01 \\
\hline & Null & & 427.1 & 42.2 & 1 & 425.1 & 0.00 \\
\hline & Native Salmonidae & Biotic Acceptance/ Resistance & 427.1 & 42.2 & 2 & 423.1 & 0.00 \\
\hline & Local catchment dam density & Human Activity & 428.1 & 43.2 & 2 & 424.1 & 0.00 \\
\hline & Network population density & Human Activity & 428.9 & 44.0 & 2 & 424.9 & 0.00 \\
\hline & Network dam density & Human Activity & 429.0 & 44.1 & 2 & 425.0 & 0.00 \\
\hline & Cumulative disturbance & Human Activity & 429.0 & 44.1 & 2 & 425.0 & 0.00 \\
\hline \multirow[t]{7}{*}{ Intermontane Plateaus } & Native Salmonidae & Biotic Acceptance/ Resistance & 1512.7 & 0.0 & 2 & 1508.7 & 0.04 \\
\hline & Cumulative disturbance & Human Activity & 1546.6 & 33.9 & 2 & 1542.6 & 0.02 \\
\hline & Native Cyprinidae & Biotic Acceptance/ Resistance & 1547.3 & 34.6 & 2 & 1543.3 & 0.02 \\
\hline & Native species richness & Biotic Acceptance/ Resistance & 1547.5 & 34.8 & 2 & 1543.5 & 0.02 \\
\hline & Network crop land use & Human Activity & 1576.5 & 63.8 & 2 & 1572.5 & 0.00 \\
\hline & Null & & 1581.7 & 69.0 & 1 & 1579.7 & 0.00 \\
\hline & Network dam density & Human Activity & 1583.5 & 70.8 & 2 & 1579.5 & 0.00 \\
\hline
\end{tabular}




\begin{tabular}{|c|c|c|c|c|c|c|c|}
\hline Spatial Extent & Variable & Hypothesis & AIC & $\triangle \mathrm{AIC}$ & $\mathrm{k}$ & Deviance & $\begin{array}{c}\text { Pseudo- } \\
R^{2}\end{array}$ \\
\hline \multirow{7}{*}{ Interior Plains } & Local catchment dam density & Human Activity & 1583.6 & 70.9 & 2 & 1579.6 & 0.00 \\
\hline & Network population density & Human Activity & 1583.7 & 71.0 & 2 & 1579.7 & 0.00 \\
\hline & Native species richness & Biotic Acceptance/ Resistance & 2378.8 & 0.0 & 2 & 2374.8 & 0.07 \\
\hline & Network crop land use & Human Activity & 2507.5 & 128.7 & 2 & 2503.5 & 0.02 \\
\hline & Native Cyprinidae & Biotic Acceptance/ Resistance & 2516.0 & 137.2 & 2 & 2512.0 & 0.01 \\
\hline & Native Salmonidae & Biotic Acceptance/ Resistance & 2536.8 & 158.0 & 2 & 2532.8 & 0.00 \\
\hline & Cumulative disturbance & Human Activity & 2541.9 & 163.1 & 2 & 2537.9 & 0.00 \\
\hline \multirow{13}{*}{$\begin{array}{l}\text { Rocky Mountain } \\
\text { System }\end{array}$} & Null & & 2545.5 & 166.7 & 1 & 2543.5 & 0.00 \\
\hline & Local catchment dam density & Human Activity & 2545.6 & 166.8 & 2 & 2541.6 & 0.00 \\
\hline & Network dam density & Human Activity & 2547.5 & 168.7 & 2 & 2543.5 & 0.00 \\
\hline & Network population density & Human Activity & 2547.5 & 168.7 & 2 & 2543.5 & 0.00 \\
\hline & Native Cyprinidae & Biotic Acceptance/ Resistance & 996.9 & 0.0 & 2 & 992.9 & 0.28 \\
\hline & Native species richness & Biotic Acceptance/ Resistance & 1147.6 & 150.7 & 2 & 1143.6 & 0.17 \\
\hline & Native Salmonidae & Biotic Acceptance/ Resistance & 1297.3 & 300.4 & 2 & 1293.3 & 0.06 \\
\hline & Cumulative disturbance & Human Activity & 1312.9 & 316.0 & 2 & 1308.9 & 0.05 \\
\hline & Local catchment dam density & Human Activity & 1369.2 & 372.3 & 2 & 1365.2 & 0.00 \\
\hline & Network dam density & Human Activity & 1370.6 & 373.7 & 2 & 1366.6 & 0.00 \\
\hline & Null & & 1373.2 & 376.3 & 1 & 1371.2 & 0.00 \\
\hline & Network crop land use & Human Activity & 1374.6 & 377.7 & 2 & 1370.6 & 0.00 \\
\hline & Network population density & Human Activity & 1375.0 & 378.1 & 2 & 1371.0 & 0.00 \\
\hline
\end{tabular}


Table 4.4. Logistic regression model results for Human Activity, Biotic Resistance, and Biotic Acceptance hypotheses predicting nonnative Catostomidae presence in the Missouri and Colorado River basins. Interior Highlands was excluded from analysis by physiographic division due to low sample size. $\mathrm{k}=$ number of model parameters.

\begin{tabular}{|c|c|c|c|c|c|c|c|}
\hline Spatial Extent & Variable & Hypothesis & $\mathrm{AIC}$ & $\Delta \mathrm{AIC}$ & $\mathrm{k}$ & Deviance & $\begin{array}{c}\text { Pseudo- } \\
R^{2}\end{array}$ \\
\hline \multirow[t]{10}{*}{ Global } & Network crop land use & Human Activity & 2176.1 & 0.0 & 2 & 2172.1 & 0.03 \\
\hline & Native Catostomidae & Biotic Acceptance/ Resistance & 2183.6 & 7.5 & 2 & 2179.6 & 0.03 \\
\hline & Physiographic division & Natural & 2210.0 & 33.9 & 4 & 2202.0 & 0.02 \\
\hline & Cumulative disturbance & Human Activity & 2223.9 & 47.8 & 2 & 2219.9 & 0.01 \\
\hline & Native Salmonidae & Biotic Acceptance/ Resistance & 2243.6 & 67.5 & 2 & 2239.6 & 0.00 \\
\hline & Null & & 2245.8 & 69.7 & 1 & 2243.8 & 0.00 \\
\hline & Network population density & Human Activity & 2246.2 & 70.1 & 2 & 2242.2 & 0.00 \\
\hline & Network dam density & Human Activity & 2246.8 & 70.7 & 2 & 2242.8 & 0.00 \\
\hline & Native species richness & Biotic Acceptance/ Resistance & 2247.5 & 71.4 & 2 & 2243.5 & 0.00 \\
\hline & Local catchment dam density & Human Activity & 2247.8 & 71.7 & 2 & 2243.8 & 0.00 \\
\hline Interior Highlands & N/A & & & & & & \\
\hline Intermontane & Cumulative disturbance & Human Activity & 517.4 & 0.0 & 2 & 513.4 & 0.07 \\
\hline \multirow[t]{8}{*}{ Plateaus } & Native species richness & Biotic Acceptance/ Resistance & 521.9 & 4.5 & 2 & 517.9 & 0.06 \\
\hline & Native Catostomidae & Biotic Acceptance/ Resistance & 525.0 & 7.6 & 2 & 521.0 & 0.05 \\
\hline & Network crop land use & Human Activity & 539.8 & 22.4 & 2 & 535.8 & 0.02 \\
\hline & Local catchment dam density & Human Activity & 550.7 & 33.4 & 2 & 546.7 & 0.00 \\
\hline & Null & & 551.1 & 33.8 & 1 & 549.1 & 0.00 \\
\hline & Network dam density & Human Activity & 552.7 & 35.3 & 2 & 548.7 & 0.00 \\
\hline & Native Salmonidae & Biotic Acceptance/ Resistance & 552.7 & 35.3 & 2 & 548.7 & 0.00 \\
\hline & Network population density & Human Activity & 553.0 & 35.6 & 2 & 549.0 & 0.00 \\
\hline \multirow[t]{4}{*}{ Interior Plains } & Native species richness & Biotic Acceptance/ Resistance & 157.9 & 0.0 & 2 & 153.9 & 0.35 \\
\hline & Native Catostomidae & Biotic Acceptance/ Resistance & 215.5 & 57.6 & 2 & 211.5 & 0.11 \\
\hline & Network crop land use & Human Activity & 230.2 & 72.3 & 2 & 226.2 & 0.05 \\
\hline & Null & & 239.3 & 81.4 & 1 & 237.3 & 0.00 \\
\hline
\end{tabular}




\begin{tabular}{|c|c|c|c|c|c|c|c|}
\hline Spatial Extent & Variable & Hypothesis & AIC & $\triangle \mathrm{AIC}$ & $\mathrm{k}$ & Deviance & $\begin{array}{l}\text { Pseudo- } \\
R^{2}\end{array}$ \\
\hline \multirow{14}{*}{$\begin{array}{l}\text { Rocky Mountain } \\
\text { System }\end{array}$} & Cumulative disturbance & Human Activity & 240.2 & 82.3 & 2 & 236.2 & 0.00 \\
\hline & Network dam density & Human Activity & 240.5 & 82.6 & 2 & 236.5 & 0.00 \\
\hline & Native Salmonidae & Biotic Acceptance/ Resistance & 240.7 & 82.8 & 2 & 236.7 & 0.00 \\
\hline & Network population density & Human Activity & 241.0 & 83.1 & 2 & 237.0 & 0.00 \\
\hline & Local catchment dam density & Human Activity & 241.3 & 83.4 & 2 & 237.3 & 0.00 \\
\hline & Native Catostomidae & Biotic Acceptance/ Resistance & 1130.1 & 0.0 & 2 & 1126.1 & 0.11 \\
\hline & Native species richness & Biotic Acceptance/ Resistance & 1185.7 & 55.6 & 2 & 1181.7 & 0.07 \\
\hline & Cumulative disturbance & Human Activity & 1202.1 & 72.0 & 2 & 1198.1 & 0.06 \\
\hline & Native Salmonidae & Biotic Acceptance/ Resistance & 1210.0 & 79.9 & 2 & 1206.0 & 0.05 \\
\hline & Network population density & Human Activity & 1256.0 & 125.9 & 2 & 1252.0 & 0.02 \\
\hline & Network dam density & Human Activity & 1257.3 & 127.2 & 2 & 1253.3 & 0.01 \\
\hline & Local dam density & Human Activity & 1258.7 & 128.6 & 2 & 1254.7 & 0.01 \\
\hline & Null & & 1273.4 & 143.3 & 1 & 1271.4 & 0.00 \\
\hline & Network crop land use & Human Activity & 1275.4 & 145.3 & 2 & 1271.4 & 0.00 \\
\hline
\end{tabular}




\section{Figures}
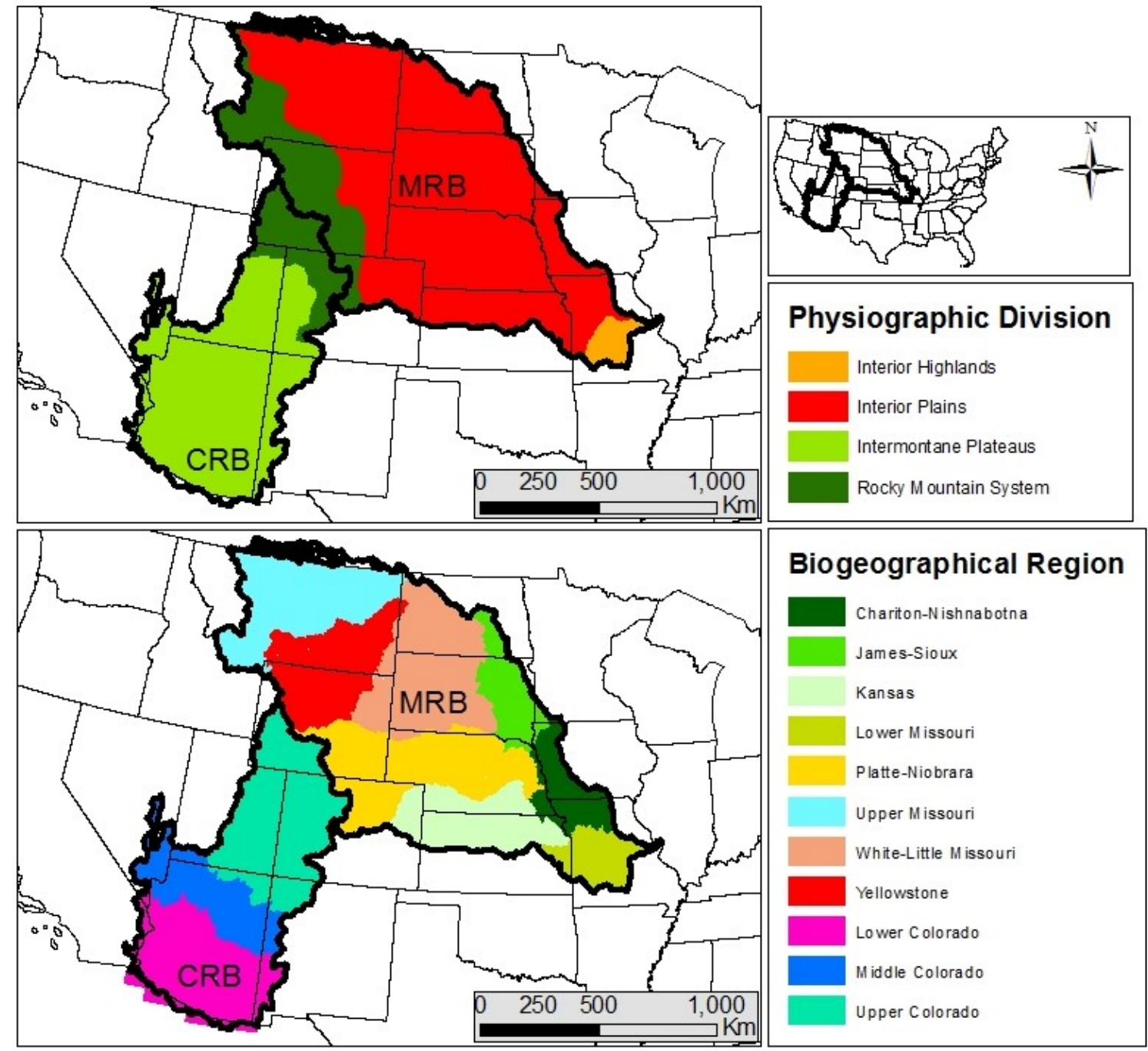

Figure 4.1. Physiographic divisions (top; Fenneman and Johnson 1946) and biogeographical regions of the Missouri and Colorado River basins (MRB and CRB, respectively). Biogeographic regions were adapted from Cross et al. (1986) for the MRB and Minckley et al. (1986) for the CRB. 

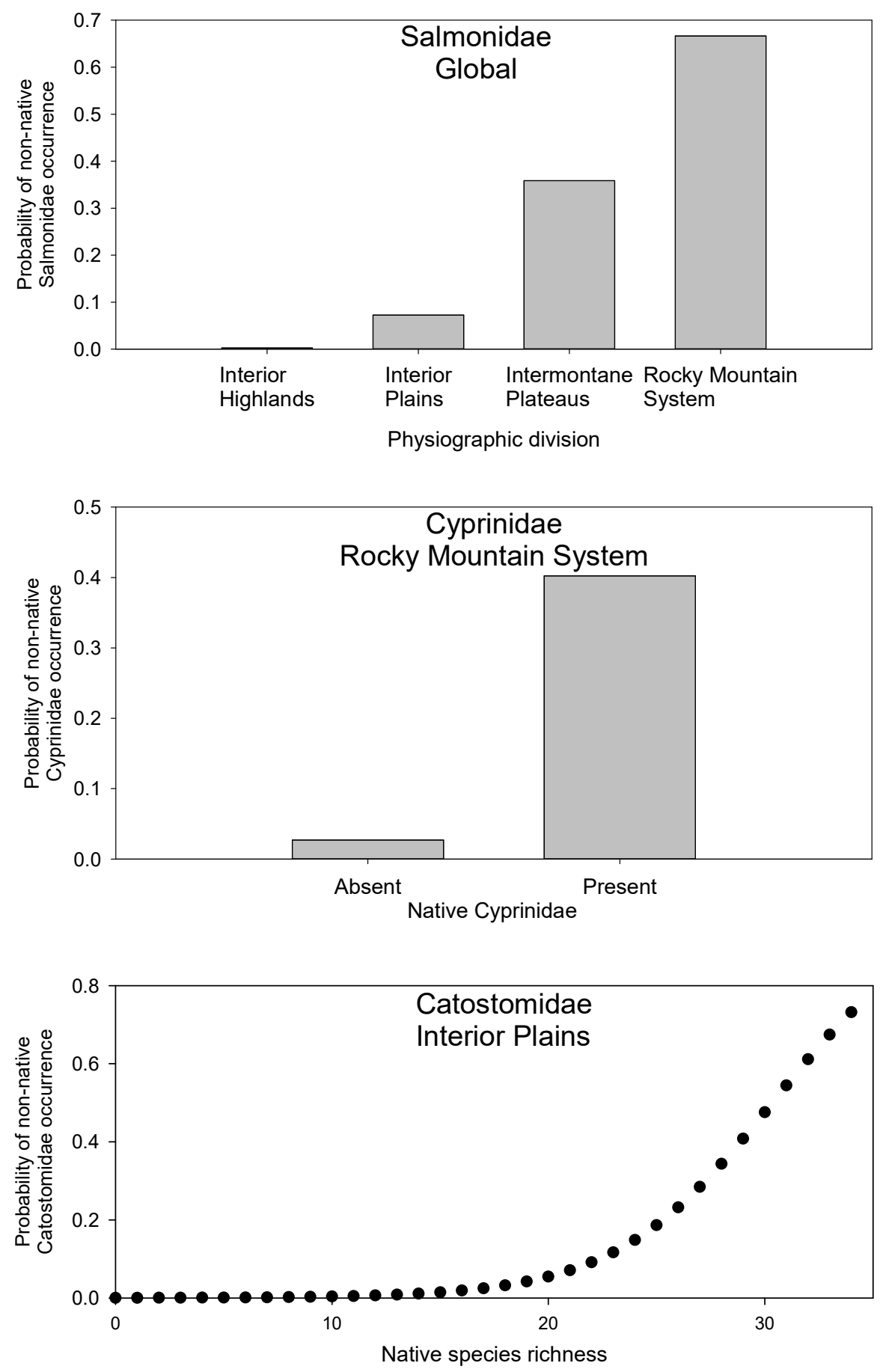

Figure 4.2. Predicted probability of non-native Salmonidae occurrence by physiographic division estimated from logistic regression at the global spatial extent (top), predicted probability of non-native Cyprinidae occurrence by native Cyprinidae occurrence in the Rocky Mountain System physiographic division (middle), and predicted probability of non-native Catostomidae occurrence as a function of native species richness in the Interior Plains physiographic division (bottom). 


\section{Appendices}

Appendix 4.1. Species occurrence (number of stream segments) and nativity by biogeographic region. An asterisk $(*)$ indicates species that were considered non-native based on Minckley et al. (1986) for the Colorado River basin and Cross et al. (1986) for the Missouri River basin. Biogeographic region abbreviations represent Chariton-Nishnabotna (CN), Kansas (KS), Lower Missouri (LM), PlatteNiobrara (PN), Sioux-James (SJ), Upper Missouri (UM), White-Little Missouri (WL), Yellowstone (YS), Lower Colorado River Basin (LC), Middle Colorado River Basin (MC), and Upper Colorado River Basin (UC).

\begin{tabular}{|c|c|c|c|c|c|c|c|c|c|c|c|c|c|}
\hline \multirow[b]{2}{*}{ Common name } & \multirow[b]{2}{*}{ Scientific name } & \multirow[b]{2}{*}{ Family } & \multicolumn{8}{|c|}{ Missouri River biogeographic region } & \multicolumn{3}{|c|}{ Colorado River biogeographic region } \\
\hline & & & $\mathrm{CN}$ & $\mathrm{KS}$ & LM & PN & SJ & UM & WL & YS & $\mathrm{LC}$ & $\mathrm{MC}$ & $\mathrm{UC}$ \\
\hline Alewife & Alosa pseudoharengus & Clupeidae & & & & $1 *$ & & & & & & & \\
\hline Arctic Grayling & Thymallus arcticus & Salmonidae & & & & & & 29 & & & $1 *$ & $1 *$ & \\
\hline $\begin{array}{l}\text { Ash Meadows } \\
\text { Amargosa Pupfish }\end{array}$ & $\begin{array}{l}\text { Cyprinodon nevadensis } \\
\text { mionectes }\end{array}$ & Cyprinodontidae & & & & & & & & & & $7 *$ & \\
\hline Banded Darter & Etheostoma zonale & Percidae & & & 36 & & & & & & & & \\
\hline Banded Sculpin & Cottus carolinae & Cottidae & & & 67 & & & & & & & & \\
\hline Bigeye Shiner & Notropis boops & Cyprinidae & & & 43 & & & & & & & & \\
\hline Bighead Carp & $\begin{array}{l}\text { Hypophthalmichthys } \\
\text { nobilis }\end{array}$ & Cyprinidae & $3 *$ & & $5^{*}$ & $1 *$ & & & & & & & \\
\hline Bigmouth Buffalo & Ictiobus cyprinellus & Catostomidae & 22 & & 21 & 2 & & & & 1 & & & \\
\hline Bigmouth Shiner & Notropis dorsalis & Cyprinidae & 429 & 17 & 77 & 96 & 27 & & 1 & & & & $1^{*}$ \\
\hline Black Buffalo & Ictiobus niger & Catostomidae & 2 & & 3 & & & & & & & & \\
\hline Black Bullhead & Ameiurus melas & Ictaluridae & 165 & 68 & 121 & 64 & 14 & $47 *$ & 36 & $70^{*}$ & $14 *$ & $2 *$ & $17^{*}$ \\
\hline Black Crappie & Pomoxis nigromaculatus & Centrarchidae & $18^{*}$ & $4^{*}$ & 26 & $3 *$ & & & $2 *$ & $3 *$ & $1^{*}$ & & $6^{*}$ \\
\hline Black Redhorse & Moxostoma duquesnei & Catostomidae & $1^{*}$ & & 93 & & & & & & & & \\
\hline Blacknose Shiner & Notropis heterolepis & Cyprinidae & & & 34 & & & & & & & & \\
\hline Blackside Darter & Percina maculata & Percidae & 17 & 2 & 9 & & 1 & & & & & & \\
\hline Blackspotted & Fundulus olivaceus & Fundulidae & & & 183 & & & & & & & & \\
\hline Topminnow & & & & & & & & & & & & & \\
\hline Blackstripe Topminnow & Fundulus notatus & Fundulidae & $1 *$ & & 122 & & & & & & & & \\
\hline Blacktail Shiner & Cyprinella venusta & Cyprinidae & & & $9 *$ & & & & & & & & \\
\hline Bleeding Shiner & Luxilus zonatus & Cyprinidae & & & 226 & & & & & & & & \\
\hline Blue Tilapia & Oreochromis aureus & Cichlidae & & & & & & & & & $1^{*}$ & & \\
\hline Bluegill & Lepomis macrochirus & Centrarchidae & $323^{*}$ & $61 *$ & 560 & $48^{*}$ & $7 *$ & & & & $12 *$ & $1^{*}$ & $9^{*}$ \\
\hline Bluehead Sucker & Catostomus discobolus & Catostomidae & & & & & & & & & $1^{*}$ & 94 & 180 \\
\hline
\end{tabular}




\begin{tabular}{|c|c|c|c|c|c|c|c|c|c|c|c|c|c|}
\hline \multirow[b]{2}{*}{ Common name } & \multirow[b]{2}{*}{ Scientific name } & \multirow[b]{2}{*}{ Family } & \multicolumn{8}{|c|}{ Missouri River biogeographic region } & \multicolumn{3}{|c|}{ Colorado River biogeographic region } \\
\hline & & & $\mathrm{CN}$ & $\mathrm{KS}$ & LM & PN & SJ & UM & WL & YS & $\mathrm{LC}$ & $\mathrm{MC}$ & $\mathrm{UC}$ \\
\hline Bluestripe Darter & Percina cymatotaenia & Percidae & & & 6 & & & & & & & & \\
\hline Bluntnose Minnow & Pimephales notatus & Cyprinidae & 233 & 30 & 480 & & 2 & & & & & & \\
\hline Bonytail Chub & Gila elegans & Cyprinidae & & & & & & & & & 3 & & 2 \\
\hline Brassy Minnow & Hybognathus hankinsoni & Cyprinidae & 60 & 10 & & 9 & 1 & 96 & 11 & 44 & & & \\
\hline Brook Silverside & Labidesthes sicculus & Atherinopsidae & $5^{*}$ & $1 *$ & 191 & $4 *$ & & & & & & & \\
\hline Brook Stickleback & Culaea inconstans & Gasterosteidae & $13 *$ & & & 2 & 2 & 131 & 10 & 55 & & & $11^{*}$ \\
\hline Brook Trout & Salvelinus fontinalis & Salmonidae & & $1^{*}$ & & $7 *$ & & $626^{*}$ & $8 *$ & $56^{*}$ & $3 *$ & $26^{*}$ & $754^{*}$ \\
\hline Brown Trout & Salmo trutta & Salmonidae & & $3 *$ & & $50 *$ & & $119^{*}$ & $16^{*}$ & $83^{*}$ & $58 *$ & $55^{*}$ & $459 *$ \\
\hline Bull Trout & Salvelinus confluentus & Salmonidae & & & & & & $7 *$ & & & & & \\
\hline Bullhead Minnow & Pimephales vigilax & Cyprinidae & & $7 *$ & $4^{*}$ & & & & & & & & \\
\hline Burbot & Lota lota & Gadidae & & & & & & 26 & & 1 & & & \\
\hline Cardinal Shiner & Luxilus cardinalis & Cyprinidae & & & $1 *$ & & & & & & & & \\
\hline Carmine Shiner & Notropis percobromus & Cyprinidae & & $12 *$ & $100^{*}$ & & & & & & & & \\
\hline Central Stoneroller & Campostoma anomalum & Cyprinidae & 345 & 70 & 579 & 35 & 4 & & 4 & & & & \\
\hline Channel Catfish & Ictalurus punctatus & Ictaluridae & 167 & 34 & 84 & 41 & 16 & 5 & 4 & 45 & $4 *$ & $7 *$ & $7^{*}$ \\
\hline Chestnut Lamprey & Ichthyomyzon castaneus & Petromyzontidae & & & 1 & & & & & & & & \\
\hline Colorado Pikeminnow & Ptychocheilus lucius & Cyprinidae & & & & & & & & & & & 10 \\
\hline Common Carp & Cyprinus carpio & Cyprinidae & $110^{*}$ & $45^{*}$ & $91 *$ & $75^{*}$ & $16^{*}$ & $85^{*}$ & $12 *$ & $84 *$ & $16^{*}$ & $7 *$ & $21 *$ \\
\hline Common Shiner & Luxilus cornutus & Cyprinidae & 75 & 26 & 178 & 7 & 3 & & 1 & & & & \\
\hline Convict Cichlid & Amatitlania nigrofasciata & Cichlidae & & & & & & & & & & $2 *$ & \\
\hline Creek Chub & Semotilus atromaculatus & Cyprinidae & 490 & 70 & 532 & 165 & 30 & $8 *$ & 28 & 78 & & & $75^{*}$ \\
\hline Cutthroat Trout & Oncorhynchus clarkii & Salmonidae & & & & & & 577 & & 99 & $1 *$ & $11 *$ & 742 \\
\hline Desert Pupfish & Cyprinodon macularius & Cyprinodontidae & & & & & & & & & 24 & & \\
\hline Desert Sucker & Catostomus clarkii & Catostomidae & & & & & & & & & 243 & 28 & \\
\hline Devils Hole Pupfish & Cyprinodon diabolis & Cyprinodontidae & & & & & & & & & & $2 *$ & \\
\hline Emerald Shiner & Notropis atherinoides & Cyprinidae & 20 & 3 & 10 & 4 & 6 & 6 & 1 & 17 & & & \\
\hline Fantail Darter & Etheostoma flabellare & Percidae & $1 *$ & & 263 & & & & & & & & \\
\hline Fathead Minnow & Pimephales promelas & Cyprinidae & 407 & 93 & 87 & 174 & 36 & 315 & 65 & 225 & $69 *$ & $90 *$ & $146^{*}$ \\
\hline Finescale Dace & Phoxinus neogaeus & Cyprinidae & & & & 1 & & & & & & & \\
\hline Flannelmouth Sucker & Catostomus latipinnis & Catostomidae & & & & & & & & & 2 & 14 & 143 \\
\hline Flathead Catfish & Pylodictis olivaris & Ictaluridae & 22 & 11 & 19 & 2 & 1 & & & & $5 *$ & & \\
\hline Flathead Chub & Platygobio gracilis & Cyprinidae & 18 & & & & & 37 & 3 & 80 & & & \\
\hline Freckled Madtom & Noturus nocturnus & Ictaluridae & & & 1 & & & & & & & & \\
\hline Freshwater Drum & Aplodinotus grunniens & Sciaenidae & 20 & 7 & 28 & 7 & 4 & & & & & & \\
\hline Ghost Shiner & Notropis buchanani & Cyprinidae & 2 & & 6 & & & & & & & & \\
\hline Gila Chub & Gila intermedia & Cyprinidae & & & & & & & & & 73 & $1 *$ & \\
\hline Gila Topminnow & Poeciliopsis occidentalis & Poeciliidae & & & & & & & & & 114 & & \\
\hline Gila Trout & Oncorhynchus gilae & Salmonidae & & & & & & & & & 76 & 8 & \\
\hline Gizzard Shad & Dorosoma cepedianum & Clupeidae & 28 & 6 & 69 & 7 & 4 & & & & & & \\
\hline
\end{tabular}




\begin{tabular}{|c|c|c|c|c|c|c|c|c|c|c|c|c|c|}
\hline \multirow[b]{2}{*}{ Common name } & \multirow[b]{2}{*}{ Scientific name } & \multirow[b]{2}{*}{ Family } & \multicolumn{8}{|c|}{ Missouri River biogeographic region } & \multicolumn{3}{|c|}{ Colorado River biogeographic region } \\
\hline & & & $\mathrm{CN}$ & $\mathrm{KS}$ & LM & $\mathrm{PN}$ & SJ & UM & WL & YS & $\mathrm{LC}$ & $\mathrm{MC}$ & $\mathrm{UC}$ \\
\hline Golden Redhorse & Moxostoma erythrurum & Catostomidae & 3 & $10^{*}$ & 148 & & & & & & & & \\
\hline Golden Shiner & Notemigonus crysoleucas & Cyprinidae & 60 & 7 & 131 & 5 & & $6^{*}$ & $8^{*}$ & $1^{*}$ & & $13^{*}$ & \\
\hline Golden Topminnow & Fundulus chrysotus & Fundulidae & & & $1 *$ & & & & & & & & \\
\hline Goldeye & Hiodon alosoides & Hiodontidae & 6 & & 3 & & 1 & 4 & 1 & 10 & & & \\
\hline Goldfish & Carassius auratus & Cyprinidae & $4 *$ & & $4 *$ & & & & & & $4^{*}$ & & $1 *$ \\
\hline Grass Carp & Ctenopharyngodon idella & Cyprinidae & $1 *$ & & $5^{*}$ & $2 *$ & & & & & $2 *$ & & $1 *$ \\
\hline Grass Pickerel & Esox americanus & Esocidae & & & & 13 & & & & & & & \\
\hline Gravel Chub & Erimystax $\mathrm{x}$-punctatus & Cyprinidae & & & 2 & & & & & & & & \\
\hline Green Sunfish & Lepomis cyanellus & Centrarchidae & 423 & 99 & 595 & 117 & 17 & $11^{*}$ & $39 *$ & $78^{*}$ & $111 *$ & $21 *$ & $33 *$ \\
\hline Greenside Darter & Etheostoma blennioides & Percidae & & & 138 & & & & & & & & \\
\hline Guppy & Poecilia reticulata & Poeciliidae & & & & & & & & & $1 *$ & & \\
\hline Headwater Chub & Gila nigra & Cyprinidae & & & & & & & & & 34 & & \\
\hline Highfin Carpsucker & Carpiodes velifer & Catostomidae & 1 & & & & & & & & & & \\
\hline Hornyhead Chub & Nocomis biguttatus & Cyprinidae & $5^{*}$ & & 122 & 3 & & & & & & & \\
\hline Humpback Chub & Gila cypha & Cyprinidae & & & & & & & & & & 4 & \\
\hline Iowa Darter & Etheostoma exile & Percidae & $2 *$ & & & 13 & 1 & 37 & 7 & & & & $2 *$ \\
\hline Johnny Darter & Etheostoma nigrum & Percidae & 222 & 49 & 207 & 14 & 7 & & $3 *$ & & & & $1 *$ \\
\hline Kokanee & Oncorhynchus nerka & Salmonidae & & & & & & & & & & & $18^{*}$ \\
\hline Lake Chub & Couesius plumbeus & Cyprinidae & & & & 1 & & 183 & 5 & 141 & & & $13^{*}$ \\
\hline Lake Trout & Salvelinus namaycush & Salmonidae & & & & & & & & & & & $5 *$ \\
\hline Largemouth Bass & Micropterus salmoides & Centrarchidae & 274 & 53 & 455 & 54 & 4 & $2 *$ & $1 *$ & $2 *$ & $28 *$ & $11^{*}$ & $10 *$ \\
\hline Largescale Stoneroller & Campostoma oligolepis & Cyprinidae & & & 161 & & & & & & & & \\
\hline Least Darter & Etheostoma microperca & Percidae & & & 13 & & & & & & & & \\
\hline Little Colorado & Lepidomeda vittata & Cyprinidae & & & & & & & & & & 36 & \\
\hline Spinedace & & & & & & & & & & & & & \\
\hline Little Colorado Sucker & Catostomus sp. & Catostomidae & & & & & & & & & & 45 & \\
\hline Loach Minnow & Rhinichthys cobitis & Cyprinidae & & & & & & & & & 33 & & \\
\hline Logperch & Percina caprodes & Percidae & $4 *$ & 14 & 230 & & & & & & & & \\
\hline Longear Sunfish & Lepomis megalotis & Centrarchidae & $2^{*}$ & $12 *$ & 328 & & & & & & & & \\
\hline Longfin Dace & Agosia chrysogaster & Cyprinidae & & & & & & & & & 321 & $1 *$ & \\
\hline Longnose Dace & Rhinichthys cataractae & Cyprinidae & & & & 101 & $9 *$ & 159 & 32 & 177 & & & $39^{*}$ \\
\hline Longnose Gar & Lepisosteus osseus & Lepisosteidae & 10 & 4 & 31 & 2 & & & & & & & \\
\hline Longnose Sucker & Catostomus catostomus & Catostomidae & & & & 27 & & 65 & 2 & 72 & & & $70 *$ \\
\hline Mexican Stoneroller & Campostoma ornatum & Cyprinidae & & & & & & & & & $4 *$ & & \\
\hline Mimic Shiner & Notropis volucellus & Cyprinidae & & & 2 & & & & & & & & \\
\hline $\begin{array}{l}\text { Missouri Saddled } \\
\text { Darter }\end{array}$ & Etheostoma tetrazonum & Percidae & & & 23 & & & & & & & & \\
\hline Mottled Sculpin & Cottus bairdii & Cottidae & & & 71 & & & $106^{*}$ & & $25^{*}$ & & & 546 \\
\hline Mountain Madtom & Noturus eleutherus & Ictaluridae & & & $1 *$ & & & & & & & & \\
\hline
\end{tabular}




\begin{tabular}{|c|c|c|c|c|c|c|c|c|c|c|c|c|c|}
\hline \multirow[b]{2}{*}{ Common name } & \multirow[b]{2}{*}{ Scientific name } & \multirow[b]{2}{*}{ Family } & \multicolumn{8}{|c|}{ Missouri River biogeographic region } & \multicolumn{3}{|c|}{ Colorado River biogeographic region } \\
\hline & & & $\mathrm{CN}$ & $\mathrm{KS}$ & LM & $\mathrm{PN}$ & SJ & UM & WL & YS & $\mathrm{LC}$ & $\mathrm{MC}$ & $\mathrm{UC}$ \\
\hline Mountain Sucker & Catostomus platyrhynchus & Catostomidae & & & & & & 47 & 2 & 67 & & & 247 \\
\hline Mountain Whitefish & Prosopium williamsoni & Salmonidae & & & & & & 26 & & 18 & & & 79 \\
\hline Mozambique Tilapia & Tilapia mossambica & Cichlidae & & & & & & & & & $1 *$ & & \\
\hline Niangua Darter & Etheostoma nianguae & Percidae & & & 15 & & & & & & & & \\
\hline $\begin{array}{l}\text { Northern Brook } \\
\text { Lamprey }\end{array}$ & Ichthyomyzon fossor & Petromyzontidae & & & 1 & & & & & & & & \\
\hline Northern Hog Sucker & Hypentelium nigricans & Catostomidae & & & 124 & & & & & & & & \\
\hline $\begin{array}{l}\text { Northern Leatherside } \\
\text { Chub }\end{array}$ & Lepidomeda copei & Cyprinidae & & & & & & & & & & & $6 *$ \\
\hline Northern Pike & Esox lucius & Esocidae & $8 *$ & & & 5 & & $37 *$ & 12 & $7 *$ & & & \\
\hline $\begin{array}{l}\text { Northern Plains } \\
\text { Killifish }\end{array}$ & Fundulus kansae & Fundulidae & & $17 *$ & $10^{*}$ & $8^{*}$ & & $9 *$ & $7 *$ & $63 *$ & & & \\
\hline $\begin{array}{l}\text { Northern Redbelly } \\
\text { Dace }\end{array}$ & Phoxinus eos & Cyprinidae & & & & & & 100 & & 9 & & & \\
\hline Northern Studfish & Fundulus catenatus & Fundulidae & & & 169 & & & & & & & & \\
\hline Orangespotted Sunfish & Lepomis humilis & Centrarchidae & 81 & 26 & 102 & 4 & 2 & & 4 & & & & \\
\hline Orangethroat Darter & Etheostoma spectabile & Percidae & 5 & 35 & 599 & & & & & & & & \\
\hline Ozark Minnow & Notropis nubilus & Cyprinidae & & & 188 & & & & & & & & \\
\hline Ozark Sculpin & Cottus hypselurus & Cottidae & & & $33 *$ & & & & & & & & \\
\hline Paddlefish & Polyodon spathula & Polyodontidae & & & 2 & & & & & & & & \\
\hline Pahrump Killifish & Empetrichthys latos & Goodeidae & & & & & & & & & & $2 *$ & \\
\hline Paiute Sculpin & Cottus beldingii & Cottidae & & & & & & & & & & & 15 \\
\hline Pealip Redhorse & Moxostoma pisolabrum & Catostomidae & & & $8 *$ & & & & & & & & \\
\hline Pearl Dace & Margariscus margarita & Cyprinidae & & & & 1 & & 12 & & & & & \\
\hline Plains Killifish & Fundulus zebrinus & Fundulidae & & & & & & & & & & $7 *$ & $7 *$ \\
\hline Plains Minnow & Hybognathus placitus & Cyprinidae & 9 & 2 & 1 & & & 53 & 4 & 60 & & & \\
\hline Plains Topminnow & Fundulus sciadicus & Fundulidae & & & 53 & 7 & & & 2 & & & & \\
\hline Pumpkinseed & Lepomis gibbosus & Centrarchidae & $1 *$ & $1 *$ & & $5 *$ & & $3 *$ & & $8^{*}$ & & & \\
\hline Quillback & Carpiodes cyprinus & Catostomidae & 72 & 8 & 19 & 14 & 4 & & & & & & \\
\hline Quitoboquito Pupfish & Cyprinodon eremus & Cyprinodontidae & & & & & & & & & $1 *$ & & \\
\hline Rainbow Darter & Etheostoma caeruleum & Percidae & & & 147 & & & & & & & & \\
\hline Rainbow Trout & Oncorhynchus mykiss & Salmonidae & & $4 *$ & $1 *$ & $29^{*}$ & & $249^{*}$ & $4 *$ & $28 *$ & $85^{*}$ & $93 *$ & $535^{*}$ \\
\hline Razorback Sucker & Xyrauchen texanus & Catostomidae & & & & & & & & & 6 & & 2 \\
\hline Red Shiner & Cyprinella lutrensis & Cyprinidae & 413 & 94 & 352 & 99 & 13 & & 2 & & $51 *$ & $11 *$ & $20 *$ \\
\hline Redbelly Tilapia & Tilapia zillii & Cichlidae & & & & & & & & & $3 *$ & & \\
\hline Redear Sunfish & Lepomis microlophus & Centrarchidae & & $2 *$ & $24 *$ & $1 *$ & & & & & $4 *$ & & \\
\hline Redfin Shiner & Lythrurus umbratilis & Cyprinidae & 93 & 19 & 333 & & & & & & & & \\
\hline Redside Shiner & Richardsonius balteatus & Cyprinidae & & & & & & & & & & & $75^{*}$ \\
\hline Ribbon Shiner & Lythrurus fumeus & Cyprinidae & & & $1 *$ & & & & & & & & \\
\hline
\end{tabular}




\begin{tabular}{|c|c|c|c|c|c|c|c|c|c|c|c|c|c|}
\hline \multirow[b]{2}{*}{ Common name } & \multirow[b]{2}{*}{ Scientific name } & \multirow[b]{2}{*}{ Family } & \multicolumn{8}{|c|}{ Missouri River biogeographic region } & \multicolumn{3}{|c|}{ Colorado River biogeographic region } \\
\hline & & & $\mathrm{CN}$ & $\mathrm{KS}$ & LM & $\mathrm{PN}$ & SJ & UM & WL & YS & $\mathrm{LC}$ & $\mathrm{MC}$ & $\mathrm{UC}$ \\
\hline Rio Grande Chub & Gila pandora & Cyprinidae & & & & & & & & & & & $2 *$ \\
\hline Rio Grande Cichlid & Herichthys cyanoguttatus & Cichlidae & & & & & & & & & & $1 *$ & \\
\hline Rio Grande Sucker & Catostomus plebeius & Catostomidae & & & & & & & & & $2 *$ & & \\
\hline River Carpsucker & Carpiodes carpio & Catostomidae & 115 & 11 & 31 & 29 & 4 & 13 & & 39 & & & \\
\hline River Shiner & Notropis blennius & Cyprinidae & 5 & 2 & & 18 & 2 & & & & & & $1 *$ \\
\hline Rock Bass & Ambloplites rupestris & Centrarchidae & & $1 *$ & $34 *$ & $2 *$ & & & $1 *$ & & & & \\
\hline Roundtail Chub & Gila robusta & Cyprinidae & & & & & & & & & 79 & 8 & 61 \\
\hline Sailfin Molly & Poecilia latipinna & Poeciliidae & & & & & & & & & & $1 *$ & \\
\hline Sand Shiner & Notropis stramineus & Cyprinidae & 423 & 65 & 269 & 164 & 33 & $31 *$ & 25 & 88 & & & $19^{*}$ \\
\hline Sauger & Sander canadensis & Percidae & 2 & & 1 & & & 1 & & 1 & & & \\
\hline Shoal Chub & Macrhybopsis hyostoma & Cyprinidae & 2 & & & 2 & & & & & & & \\
\hline Shortfin Molly & Poecilia mexicana & Poeciliidae & & & & & & & & & & $2 *$ & \\
\hline Shorthead Redhorse & $\begin{array}{l}\text { Moxostoma } \\
\text { macrolepidotum }\end{array}$ & Catostomidae & 43 & 10 & 23 & 28 & 11 & 15 & 6 & 50 & & & \\
\hline Shortnose Gar & Lepisosteus platostomus & Lepisosteidae & 21 & & 28 & 2 & 4 & & 1 & & & & \\
\hline Silver Carp & $\begin{array}{l}\text { Hypophthalmichthys } \\
\text { molitrix }\end{array}$ & Cyprinidae & $4^{*}$ & & $1 *$ & & & & & & & & \\
\hline Silver Chub & Macrhybopsis storeriana & Cyprinidae & 11 & & 2 & & & & & & & & \\
\hline Silver Redhorse & Moxostoma anisurum & Catostomidae & & & 13 & & & & & & & & \\
\hline Slender Madtom & Noturus exilis & Ictaluridae & 1 & 14 & 249 & & & & & & & & \\
\hline Slenderhead Darter & Percina phoxocephala & Percidae & $1^{*}$ & $1 *$ & 30 & & & & & & & & \\
\hline Slough Darter & Etheostoma gracile & Percidae & & & 4 & & & & & & & & \\
\hline Smallmouth Bass & Micropterus dolomieu & Centrarchidae & & & 91 & $3 *$ & $1^{*}$ & $3 *$ & & $3 *$ & $20 *$ & & $13^{*}$ \\
\hline Smallmouth Buffalo & Ictiobus bubalus & Catostomidae & 9 & & 17 & & & 1 & & 1 & & & \\
\hline Sonora Chub & Gila ditaenia & Cyprinidae & & & & & & & & & $12 *$ & & \\
\hline Sonora Sucker & Catostomus insignis & Catostomidae & & & & & & & & & 130 & & \\
\hline $\begin{array}{l}\text { Southern Redbelly } \\
\text { Dace }\end{array}$ & Phoxinus erythrogaster & Cyprinidae & $7 *$ & 26 & 137 & & & & & & & & \\
\hline Speckled Dace & Rhinichthys osculus & Cyprinidae & & & & & & & & & 256 & 143 & 467 \\
\hline Spikedace & Meda fulgida & Cyprinidae & & & & & & & & & 2 & & \\
\hline Spotfin Shiner & Cyprinella spiloptera & Cyprinidae & $6^{*}$ & & & & & & & & & & \\
\hline Spottail Shiner & Notropis hudsonius & Cyprinidae & & & & & 1 & $17 *$ & & $1 *$ & & & \\
\hline Spotted Bass & Micropterus punctulatus & Centrarchidae & $3^{*}$ & & $104 *$ & & & & & & & & \\
\hline Spotted Sucker & Minytrema melanops & Catostomidae & & & $7 *$ & & & & & & & & \\
\hline Stippled Darter & Etheostoma punctulatum & Percidae & & & 115 & & & & & & & & \\
\hline Stonecat & Noturus flavus & Ictaluridae & 88 & 15 & 21 & 35 & 13 & 16 & 8 & 32 & & & \\
\hline Striped Bass & Morone saxatilis & Moronidae & & $2 *$ & & & & & & & $1 *$ & $2 *$ & \\
\hline Striped Shiner & Luxilus chrysocephalus & Cyprinidae & & & 109 & & & & & & & & \\
\hline Sturgeon Chub & Macrhybopsis gelida & Cyprinidae & & & & & & & & 2 & & & \\
\hline
\end{tabular}




\begin{tabular}{|c|c|c|c|c|c|c|c|c|c|c|c|c|c|}
\hline \multirow[b]{2}{*}{ Common name } & \multirow[b]{2}{*}{ Scientific name } & \multirow[b]{2}{*}{ Family } & \multicolumn{8}{|c|}{ Missouri River biogeographic region } & \multicolumn{3}{|c|}{ Colorado River biogeographic region } \\
\hline & & & $\mathrm{CN}$ & $\mathrm{KS}$ & LM & PN & SJ & UM & WL & YS & $\mathrm{LC}$ & $\mathrm{MC}$ & $\mathrm{UC}$ \\
\hline Suckermouth Minnow & Phenacobius mirabilis & Cyprinidae & 242 & 41 & 135 & 22 & 1 & & & & & & \\
\hline Tadpole Madtom & Noturus gyrinus & Ictaluridae & 17 & & 10 & & 1 & & $1 *$ & & & & \\
\hline Threadfin Shad & Dorosoma petenense & Clupeidae & & & & & & & & & $2 *$ & & \\
\hline Topeka Shiner & Notropis topeka & Cyprinidae & 7 & 14 & 17 & & & & & & & & \\
\hline Trout-perch & Percopsis omiscomaycus & Percopsidae & 12 & & & & & & & & & & \\
\hline Utah Chub & Gila atraria & Cyprinidae & & & & & & & & & & & $4 *$ \\
\hline Utah Sucker & Catostomus ardens & Catostomidae & & & & & & & & & & & $1 *$ \\
\hline Virgin River Chub & Gila seminuda & Cyprinidae & & & & & & & & & & 1 & \\
\hline Virgin Spinedace & Lepidomeda mollispinis & Cyprinidae & & & & & & & & & & 19 & \\
\hline Walleye & Sander vitreus & Percidae & $6 *$ & & & $2 *$ & $1 *$ & $8^{*}$ & $3 *$ & $2 *$ & & $1 *$ & \\
\hline Warm Springs Pupfish & $\begin{array}{l}\text { Cyprinodon nevadensis } \\
\text { pectoralis }\end{array}$ & Cyprinodontidae & & & & & & & & & & $2 *$ & \\
\hline Warmouth & Lepomis gulosus & Centrarchidae & & & 38 & & & & & & & & \\
\hline Wedgespot Shiner & Notropis greenei & Cyprinidae & & & 17 & & & & & & & & \\
\hline $\begin{array}{l}\text { Western Blacknose } \\
\text { Dace }\end{array}$ & Rhinichthys obtusus & Cyprinidae & $28 *$ & & & & $2 *$ & & & & & & \\
\hline Western Mosquitofish & Gambusia affinis & Poeciliidae & $29^{*}$ & $12 *$ & $216^{*}$ & $29^{*}$ & & & & & $73 *$ & $5 *$ & $2 *$ \\
\hline $\begin{array}{l}\text { Western Silvery } \\
\text { Minnow }\end{array}$ & Hybognathus argyritis & Cyprinidae & 2 & & & & & 35 & 2 & 71 & & & \\
\hline White Bass & Morone chrysops & Centrarchidae & 4 & $2 *$ & 6 & & $2 *$ & & & & & & $1 *$ \\
\hline White Crappie & Pomoxis annularis & Centrarchidae & 56 & 15 & 75 & 7 & 1 & $2 *$ & $1 *$ & $1 *$ & & & \\
\hline White Perch & Morone americana & Moronidae & & & & $2 *$ & & & & & & & \\
\hline White River Spinedace & Lepidomeda albivallis & Cyprinidae & & & & & & & & & & 1 & \\
\hline White River Springfish & Crenichthys baileyi & Goodeidae & & & & & & & & & & 4 & \\
\hline White Sucker & Catostomus commersonii & Catostomidae & 234 & 45 & 268 & 136 & 17 & 244 & 45 & 192 & & & $207^{*}$ \\
\hline Woundfin & Plagopterus argentissimus & Cyprinidae & & & & & & & & & & 2 & \\
\hline Yaqui Chub & Gila purpurea & Cyprinidae & & & & & & & & & $3 *$ & & \\
\hline Yellow Bass & Morone mississippiensis & Moronidae & $1 *$ & & & & & & & & & & \\
\hline Yellow Bullhead & Ameiurus natalis & Ictaluridae & 190 & 47 & 284 & 27 & & $2 *$ & $1 *$ & $7 *$ & $41 *$ & $2 *$ & \\
\hline Yellow Perch & Perca flavescens & Percidae & $6^{*}$ & & & & & $23 *$ & $4 *$ & $14^{*}$ & & & $5^{*}$ \\
\hline
\end{tabular}




\section{CHAPTER 5- MANAGEMENT IMPLICATIONS AND FUTURE RESEARCH}

\section{Summary}

In this study, I used landscape-level environmental data and fish sampling records to explain patterns in fish distributions and inform lotic fish conservation efforts. First, I developed an approach to identify potentially ecologically important tributaries (PEITs) using watershed characteristics and evaluated the effects of these tributaries on smallbodied fish assemblage (Chapter 2). Using this approach, I identified one PEIT for the middle Missouri River, three for the San Juan River, and four each for the lower Missouri, upper Colorado, and lower Green Rivers that may be targeted for conservation efforts because they are likely to affect flow, sediment, or temperature regimes of these mainstem rivers, assuming these factors are driven by watershed area, surficial lithology, and dam storage density. This approach also provides management agencies with information that may be used to prioritize tributaries for restoration and protection. For example, the Osage River may be targeted for restoration because it increased mainstem Missouri River hydrological alteration (measured by dam storage density), whereas the Niobrara and Platte Rivers could be prioritized for protection because they reduced mainstem hydrological alteration. Finally, this approach for identifying PEIT can be used to delineate ecologically relevant sampling reaches and may identify tributaries that have distinct chemical signatures for microchemistry studies; both of these applications are likely to improve our understanding of large river ecology and, subsequently, conservation efforts. 
My research on spatial transferability of species distribution models (SDMs; Chapter 3) and the drivers of non-native species establishment (Chapter 4) provided insights into the factors associated with non-native species occurrences that can inform management actions, but also suggested that caution should be used when implementing management actions based on predicted distributions of non-native species. First, SDMs transferred spatially for $60 \%$ of the species that I evaluated, suggesting that SDMs may be used in some cases (e.g., when important predictor variables and species-variable relationships are consistent between regions) to predict areas of non-native species establishment. However, transferability was not predictable by species characteristics and may be species- and context-specific, so it is unclear when it would be appropriate to implement management decisions based on spatially-transferred SDMs. Second, these studies suggested natural environmental factors may be the most important factors driving non-native species at the stream segment spatial grain because natural factors were often identified as the most important variables in SDMs (Chapter 3), and metrics of human activity and the native fish assemblage rarely resulted in models that explained substantial variability in the probability of non-native family occurrence (Chapter 4). Third, I found that support for the hypothesized drivers of non-native family occurrence varied by spatial extents and families, suggesting that results from studies at coarse taxonomic scales and across large spatial extents may not be reliably generalized to other taxonomic groups or spatial extents. Therefore, results from large-scale studies may not adequately explain the drivers of non-native species at smaller scales that are more applicable to resource managers. Finally, although I found little evidence of differences in SDM transferability related to species characteristics, it is concerning that the species 
characteristics that were hypothesized to result in high SDM transferability (e.g., highly specialized traits) are opposite those of species that were expected to be successful invaders (e.g., generalist species). Therefore, using SDMs to predict future distributions of non-native species could have limited utility if the hypothesized relationships between species characteristics, SDM transferability, and invasion success are correct.

In conclusion, understanding how landscape-scale environmental factors structure lotic ecosystems can improve conservation efforts, but care should be taken to ensure that appropriate spatial and taxonomic scales are considered. In this study, I found that the effects of PEIT on fish assemblage structure and the drivers of non-native species varied among rivers (Chapter 2) and spatial extents (Chapters 3 and 4). These results highlight the need to focus research efforts on spatial and taxonomic scales relevant to resource managers. Although large-scale (e.g., global spatial extent and species richness) analyses may identify interesting ecological patterns, studies at these scales may have limited value to decision-makers that manage individual species or watersheds. Furthermore, these large-scale studies may provide correlative relationships, but may not identify mechanistic linkages that are needed to provide confidence that management actions will be effective.

\section{Future Research}

Our understanding of the value of tributaries to large river conservation could be improved by research that identifies the mechanisms responsible for tributary effects on abiotic and biotic components of large river ecosystems. My results showed that PEIT may affect small-bodied fish assemblage structure, but my ability to evaluate potential mechanisms responsible for the effects of PEIT was limited by insufficient data adjacent 
to numerous PEIT, the fact that PEIT were often identified by multiple landscape factors, and the limited availability of abiotic and biotic response data. In this study, I limited analysis to small-bodied fish assemblage structure because fish sampling data was readily available for large rivers from the Pallid Sturgeon Population Assessment Program and the Upper Colorado River Endangered Fish Recovery Program, whereas large-scale data was limited for abiotic factors and lower trophic levels (e.g., invertebrates). Future research could improve our understanding of the mechanisms responsible for tributary effects by focusing research efforts on tributaries identified by only one landscape factor to reduce potential confounding of multiple mechanisms operating simultaneously. Furthermore, future studies could provide a more complete understanding of tributaries by studying their effects on abiotic and biotic metrics directly related to tributary inputs. For example, a potential study design would be to evaluate the effects of tributaries identified by surficial lithology on substrate composition, turbidity, and, subsequently, the abundance and diversity of fish and invertebrates using a traits-based approach (e.g., substrate and turbidity preferences).

Our understanding of the drivers of non-native fish establishment in lotic ecosystems could be improved by 1) resolving issues related to spatial scale, 2) incorporating natural abiotic factors, biotic factors, and metrics of human activity as predictor variables when evaluating the drivers of non-native species, and 3) synthesizing the results of non-native SDMs across species. First, I found it challenging to synthesize the results of previous studies that evaluated the hypothesized drivers of species invasions because spatial grain and spatial scales were not always clearly identified and often varied among studies. In addition to improved consistency and clarity in spatial scale 
reporting, I suggest that examining species invasions as a stepwise habitat filtering process (Tonn 1990; Poff 1997; Jackson et al. 2001) may provide valuable insight on the effects of spatial scale on the drivers of species invasions. Second, I did not include natural abiotic factors as potential predictors of non-native family occurrence (Chapter 4) because previous studies supported the hypothesized drivers without inclusion of natural factors in their analyses, but these models generally explained little variability (pseudo- $R^{2}$ $<0.2$ ) in non-native family occurrence in this study. Meanwhile, I did not include biotic metrics as predictor variables in SDMs because fish sampling data is likely unavailable for most areas of potential non-native species introduction, so including these variables would not accurately represent SDMs used to predict non-native species invasions. However, including the suite of biotic, natural, and anthropogenic factors into these analyses (e.g., Chapters 3 and 4) could help identify whether human activity and native fish assemblage structure are the primary drivers of non-native species occurrence, or if these factors are of secondary importance to natural factors. Finally, comparing nonnative SDMs that incorporate natural factors, human activity, and the native fish assemblage metrics as predictor variables among multiple species could help identify patterns in the drivers of non-native species. Studies that evaluate the drivers of nonnative species establishment at the species taxonomic scale are likely more informative than studies at generalized biotic scales (e.g., non-native species richness) because they do not assume that the drivers of establishment are similar among species that may have different traits and ecology (Lapointe and Light 2012). It is unlikely that this assumption is met in all situations because my research showed that the primary abiotic drivers of species distributions varied among basins for most species (Chapter 3) and the drivers of 
non-native family occurrence differed among families and spatial extents (Chapter 4). By evaluating the drivers of individual species distributions first, then comparing these results across species, one could evaluate which hypotheses (i.e., Biotic Resistance, Biotic Acceptance, and Human Activity) are most-supported even if the specific variables driving distributions differ among species. This type of study would fill a gap in the invasive species literature because most studies at the species taxonomic scale focus on a limited number of species, and studies that model distributions of numerous species rarely synthesize their results in the context of the drivers of non-native species (e.g., Chapter 3).

\section{References}

Lapointe, N. W. R., and T. Light. 2012. Landscape-scale determinants of non-native fish communities. Biodiversity Research 18:282-293.

Poff, N. L. 1997. Landscape filters and species traits: Towards mechanistic understanding and prediction in stream ecology. Journal of the North American Benthological Society 16:391-409.

Jackson, D. A., P. R. Peres-Neto, and J. D. Olden. 2001. What controls who is where in freshwater fish communities- the roles of biotic, abiotic, and spatial factors. Canadian Journal of Fisheries and Aquatic Sciences 58:157-170.

Tonn, W. M. 1990. Climate change and fish communities: A conceptual framework. Transactions of the American Fisheries Society 119:337-352. 


\section{VITA}

Landon Pierce obtained a Bachelor of Science in Fisheries and Wildlife from the University of Nebraska-Lincoln in 2007, and a Master of Science in Wildlife and Fisheries Sciences from South Dakota State University in 2010. From 2014 to 2019, Landon worked for the U.S. Fish and Wildlife Service as the lead biologist on the Pallid Sturgeon Population Assessment Program for the Missouri River from Fort Randall Dam, SD, to Lewis and Clark Lake, NE-SD. 